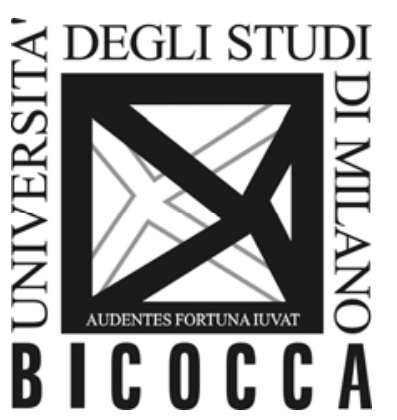

\author{
DEPARTMENT OF ECONOMICS, \\ MANAGEMENT AND STATISTICS \\ UNIVERSITY OF MILAN - BICOCCA
}

DEMS WORKING PAPER SERIES

\title{
Does International Migration Increase Child Labor?
}

Anna De Paoli and Mariapia Mendola

No. 231 - June 2012

Dipartimento di Economia, Metodi Quantitativi e Strategie di Impresa

Università degli Studi di Milano - Bicocca

http://dems.unimib.it/ 


\title{
Does International Migration Increase Child Labor?*
}

\author{
Anna De Paoli ${ }^{\dagger}$ and Mariapia Mendola ${ }^{\ddagger}$
}

This version: July 2012

\begin{abstract}
Global international migration may influence child labor through a labor market effect. We empirically investigate this issue by using an original cross-country survey dataset, which combines information on international emigration flows with detailed individual-level data on child labor at age 5-15 in a wide range of developing countries. By using variation in the emigration supply shocks across labor market units defined on the basis of both geography and skill, we estimate a set of child labor equations where the variable of interest is the interactive effect between parental skill and country-level emigration shocks. We measure the latter through different indicators including a direct measure of the relative skill compostion of emigrants relative to the resident population in the country of origin. Overall, after controlling for a large set of individual-level characteristics, remittances, and country fixed effects, our findings are consistent with predictions and show that international out-migration may significantly reduce child labor in disadvantaged households through changes in the local labor market.
\end{abstract}

Keywords: International Migration, Child Labor, Factor Mobility, Crosscountry Survey Data

JEL classification: F22, F1, J61

${ }^{*}$ We thank Simone Bertoli, Frédéric Docquier, Marco Manacorda, Anna Maria Mayda and seminar participants at the 5th Migration and Development Conference in Paris, the 2012 CSAE Conference in Oxford, the 11th Journées LAGV in Marseille, DIW Berlin, Bocconi University and University of Florence for useful comments and suggestions. We are grateful to Juan Miguel Gallego for valuable inputs at an early stage of the project. Financial support from Centro Studi Luca d'Agliano (LdA) is gratefully aknowledged. Usual disclaimer applies.

${ }^{\dagger}$ Department of Economics, Università di Milano Bicocca, Piazza dell'Ateneo Nuovo 1, 20126 Milano, Italy. E-mail: anna.depaoli@unimib.it

${ }^{\ddagger}$ Corresponding author. Department of Economics, Università di Milano Bicocca and LdA, Piazza dell'Ateneo Nuovo 1, 20126 Milano, Italy. E-mail: mariapia.mendola@unimib.it 


\section{Introduction}

A global picture of child labour shows that in 2008 approximately 215 million children between 5 and 14 years old are at work (both market and domestic work), 61 percent of whom are in Asia, 32 percent are in Africa, and 7 percent are in Latin America (ILO 2010). The persistence of the phenomenon has led to a growing interest in understanding its causes and consequences and several explanations have been provided, including the need for extra household income to achieve minimum consumption, credit constraints combined with poverty and agency problems (e.g. Basu and Van, 1998; Baland and Robinson, 2000).

More recently, several observers have highlighted the role of globalization and market integration in shaping the incidence and intensity of child labour in developing countries (Dinopoulos and Zhao, 2007; Edmonds and Pavcnik, 2005 and Epstein and Kahana, 2008). In particular, it has been observed that both international trade and migration may influence child labour in low-income settings through their impact on the labour market (Dinopoulos and Zhao, 2007 and Epstein and Kahana, 2008). Yet, while there is some evidence of the little or no harm of international trade on child work (Cigno et al, 2002; Edmonds and Pavcnik, 2005), the labor market impact of global migration flows on children in countries of origin has received little empirical attention.

International migration, mainly from poor to rich countries, has risen steadily over the last three decades. By the 2000s, some developing countries have lost a substantial fraction of their population to emigration. Emigrants account for some $10 \%$ of the population of Mexico, and as much as $20-30 \%$ in smaller countries such as Albania or Trinidad and Tobago. The sheer scale of the cross-border movements of people has raised much interest and a number of concerns about its economic impact on the labor-market in source countries. In an important empirical paper on the labor market impact of emigration, Mishra (2007) shows that Mexican emigration to the United States over the period 1970-2000 has a strong and positive effect on Mexican wages (see also Hanson, 2008, 2007). Yet, while the focus has been mainly on the adult labor force, little is known on child work in migrant-sending regions. 
The purpose of this paper is to provide new empirical evidence on the consequences of global international migration flows on the incidence and intensity of child labor in less developed countries. In particular, we provide a quantitative assessment of the global impact of the observed levels of emigration on child labor in the countries of origin, taking explicitly into account the skill composition of both the migrant and the resident labor forces.

We use an original dataset which combines information on the skill and gender composition of migrants in each sending country with detailed individual- and household-level survey data on child labour (Docquier et al., 2007; MICS II-UNICEF, 2000). The data also allow us to characterize the type of activity in which each child is employed, i.e. market work, family business or domestic work. We hence generate a large cross-country survey dataset on more than 200,000 children aged 5-15 from 38 developing countries. The combination of detailed survey data on child labor with information on international migration outflows allows us to test for interactive effects between individual (parental) characteristics and country-level attributes.

According to the theory the correlation between child labor and international emigration may be at work through a labor market effect. Indeed, significant labor force emigration leads to a tightening of the local labor supply, which induces both income and substitution effects working in opposite directions. To the extent that labor migration outflows generate higher wages for adults, and leisure (schooling) is a normal good, childrens' labor market participation will fall (Basu and Van, 1998). On the other hand, if emigration is also associated to a rise in children's wages, this might lead to an increase in children's labor market participation (Cigno and Rosati, 2005, Manacorda and Rosati, 2010, Edmonds and Pavcnik 2005). These competing effects, though, are likely to depend on the characteristics of emigrants with respect to stayers, as well as on household and child attributes. In particular, the substitution effect is likely to be at work if emigration is relatively low-skilled with respect to stayers, since children typically compete in the low-skilled labor market. At the same time, the improved labor market conditions faced by households with lower levels of education can still raise family incomes in a way that tends to reduce child labor. 
Furthermore, the above effects are likely to be differentiated according to a set of household and individual (of the parent and of the child) attributes such a gender, age, wealth conditions, living area. This is so as child productivity, returns to investment in human capital and parental preferences over their children's time use are likely to differentially interact with the emigration impact.

It should be noted that household (and aggregate) income gains may also come from migrants' remittances. Even though we are interested in the comprehensive effect of migration (see McKenzie and Sasin, 2007), in our empirical analysis we further control for the effect of remittances as to reveal the migration 'net' effect.

Overall, whether the labour market impact of emigration on children in sending countries is at work through changes in income or incentives for work is theoretically ambiguous a priori. By taking advantage of our data that allow to use interaction terms between individual level characteristics and country level emigration flows, we are able to estimate the dominating force at work.

Our results show that international migration plays a significant role in shaping family decisions on children's time allocation in migrant-sending countries. In particular, the overall level of migration has a negative effect on the labor supply of children. Moreover, when disaggregating migration rates by skill, we find that children with lower educated parents are less likely to supply labor the higher is low-skilled emigration. We further use a direct measure of the skill composition of emigrants relative to stayers as to better measure the labor market competition effect. We find that the lower is the emigration skill composition with respect to the local labor force, the higher is the probability of low-skilled parents to withdraw their children from the labor market. Decomposing further migration outflows by gender, we find that female migration is strongly related to a decrease in children's labor supply, whilst male migration does affect child labor to a smaller extent. Finally, it is younger children, boys and those who belong to poorer hosueholds who largely decrease their labor supply in response to emigration flows and labor market changes. This is consistent with a simple model where child labor and schooling in developing countries are ultimately the result of poverty (Edmonds and Pavnik, 2005). 
Our findings shed new light on contentious effects of skilled and unskilled international migration on child labour, while contributing to the general debate on the consequence of labor mobility on sending countries by looking not only at education but also at child work. The way that households respond in terms of their children's time use to emigration supply shocks and labor market incentives has relevant policy implications for both poverty alleviation and international migration management in developing countries.

The rest of the paper is organised as follows. Section 2 describes the theoretical background and related literature. Section 3 presents the data and descriptive statistcs. Section 4 describes the empirical strategy while Section 5 presents results. Section 6 concludes.

\section{Background Literature}

Standard theory on factors' mobility suggests that globalization and economic integration across national borders may have an impact on child labour mainly through changes in the competitive labor market that lead to both substitution and income effects. Indeed, global market integration may increase labor demand of both adults and children. Yet, the greater demand for adult labor can raise family incomes in a way that tends to reduce child labor (Manacorda and Rosati, 2010; Edmonds and Pavcnik, 2005b). By using both cross-country and household level data, Edmonds and Pavcnik (2005a, 2006) provide systematic evidence that there is a decline in child labor upon the increase of trade liberalization, maily driven by the positive association between openness and income (see also Cigno and Rosati, 2002; Edmonds and Pacvnik, 2005b, among others). On the same theoretical ground, there is a direct relationship between international labor mobility and local labor market conditions. Ceteris paribus, a negative labor supply shock induced by emigration yields a shortrun increase in the wage rate of workers left behind- while long-run effects will depend on the relative magnitude of potential emigration-induced changes in labor demad. In a seminal empirical paper, Lucas (1987) uses annual time series data from 1946 to 1978 on sectoral wage and employment to show that mine worker emigration to 
South Africa has raised agricultural wages in Malawi and Mozambique (see also Lucas, 2005). Yet, several contributions on the economics of migration have observed that the labor market impact of migration is uneven across the population, and the main income-distribution effects depend on the skill composition of emigrants (immigrants) relative to stayers in the source country (natives in the destination country) (e.g., Borjas, 1987; Altonji and Card, 1991). ${ }^{1}$ According to the latter framework, if emigrants are on average less skilled then stayers, they will hurt skilled natives and benefit unskilled ones, as their departure will induce an increase in the unskilled wage and a decrease in the skilled one. Conversely, if emigrants are relatively more skilled than stayers, unskilled stayers will be hurt in the labor market, whereas skilled ones will benefit from their departure.

These theoretical predictions has been tested by the empirical literature studying the impact of immigration on the wage structure, using various identification strategies. One major strand of the literature identifies the direct effect on wages of native workers experiencing immigration-induced increases in labor supply, by using variation in the immigrant share across labor market units. The definition of the latter units is mostly based on geography and skill, where the latter is measured by the level of education (and experience or occupation, when available) (e.g., Card, 2001; 2005; Borjas, 2003). ${ }^{2}$

In contrast, the first empirical contribution testing the labor-market impact of emigration using spatial variation and individual-level data is Mishra (2007). The latter study combines U.S. census data on the volume of Mexican emigration to the US with Mexican census data on individuals in the labor force to assesses the impact of the outflow of workers on Mexican wages. By employing the same approach as above (i.e. by using the supply shifts in skill groups induced by emigration), the

\footnotetext{
${ }^{1}$ In particular, it has been shown that the wage impact of immigration for native workers will depend on the skill composition of immigrants and the substitutability between immigrant and native labor (within skill group) as well as the degree of substitution between workers with different qualifications (Ottaviano and Peri 2011). Yet, when studying emigration from the same country the degree of substitutability is less of a concern.

${ }^{2}$ The definition of labor market units based on geography ('the spatial correlation approach') has been subject of debate, the conclusion of which may be that, when dealing with migration, the labor market of reference is the one at the national level (see Borjas, 2003)- framework that we follow in our cross-country analysis.
} 
author finds that a 10 percent increase in emigration, on average, increases wages in Mexico by almost 4 percent. Consistently with the latter piece of evidence, Aydemir and Borjas (2007) use individual data drawn from the Canadian, Mexican, and U.S. Censuses and show that a 10 percent change in labor supply is associated with a 3 to 4 percent change in wages in the opposite direction. In a study of Puerto Rican workers, Borjas (2008) finds that a 10 percent emigration-induced fall in the number of workers in a particular skill group raises the average wage by about 2 percent. Finally, in a more recent paper Bouton et al. (2011) use household survey data to examine the impact of emigration on wages in Moldova, another country where emigration of the labour force is significant. Results show that emigration flows from Moldova yields a positive and significant impact on wages at origin, and the magnitude of the effect is close to the one estimated by Mishra (2007). ${ }^{3}$

Overall, by inducing an income-distribution effect across the population, the wage increase emanating from the fall in adult labor supply may affect child labor. In particular, emigration of skilled workers are expected to reduce the incidence of child labor through an increase of the relative wage rate of educated people. The opposite holds for economic integration that raises returns of low-education (Edmonds, et al 2006, 2008; Cigno et al. 2002). Dinopoulos and Zhao (2007) use a general equilibriummodel to show that emigration of unskilled (skilled) workers increases (reduces) the incidence of child labor via a labor substitution effect. On the contrary, Epstein and Kahana (2008) argue that temporary emigration of unskilled workers might help households overcoming a minimal survival income threshold that would lead to a reduction in the incidence of child labor. Taking into account both the cost of the family's temporary separation and the benefit of receving remittances, the household income effect would reduce labor supply, increase wages and allow both migrant- and non-migrant-households to take their children out of the labor force. Overall, given

\footnotetext{
${ }^{3}$ Using different approaches and focusing more on geographic (or sector) averages rather than individuals, other contributions have shed light on the labor market impact of emigration in countries of origin. Robertson (2000), Chiquiar (2004), and Hanson (2004) for example provide evidence that those Mexican states that have greater international trade and migration links have enjoyed faster growth in average income and labor earnings. In addition, the impact of emigration on wages in Mexico has been largest in states with well-developed U.S. emigrant networks (Munshi, 2003). In yet another study, Hanson (2006) suggests that average hourly earnings in states with high emigration rates increased by 6 to 9 percent, compared to states with low emigration rates.
} 
competing effects of changes in income vs incentives for work, how international migration shapes the incidence of child labor in coutries of origin is an empirical question with no unambigous answer.

Also from the perspective of the economic theory of the household, international migration (i.e. gendered or skill-biased migration) may have an ambiguos net effect on child time allocation between labor and schooling. Indeed, given that decisions about how to allocate child time are mainly made by a parent, if parents care about their own and their children's consumption, key roles in determining child labor or schooling will be ultimately played by: (i) the direct and opportunity cost of education, (ii) the expected return to education and (iii) access to capital markets (Cigno and Rosati, 2002, Grootaert and Kanbur, 1995). Therefore, as long as labor migration outflows determine a change in wage rates (potentially coupled with remittance capital inflows), it is possible for parents to shift their children's time allocation. In particular, unskilled labour outflows make expected returns to education fall and child labor increase through a substitution effect. At the same time though, a positive income effect, stronger among children of parents with low levels of education, may increase child schooling, leading to an ambiguos net effect on children time allocation. On the other hand, if out-migration is more concentrated among educated workers, skilled wage rate, as well as returns to education, will rise making child labor participation fall. This effect will be potentially stronger in households with relatively higher educated adults/parents than in households where adults are low-educatedeven though in such skilled households child labor is a less relevant issue. It should be noted, though, that if there is some degere of complementarity in production between skilled and unskilled workers, skilled (low-skilled) outmigration may still influence labor supply of children of low-educated (educated) parents via a negative effect on wages of the uneducated workers left behind (see Docquier et al. 2011). ${ }^{4}$

Micro-economic evidence on the effects of international migration on child human capital accumulation is mixed. The latter body of literature has largely focused

\footnotetext{
${ }^{4}$ According to the economic theory, emigration form a (closed) labor market affect the wage structure in that market by increasing the wage of competing workers and decreasing the wages of complements (Borjas, 2003).
} 
on the impact of an increase in household income via remittances on accumulated schooling, finding some positive effects (see, for example, Cox Edwards and Ureta 2003, Lopez Cordoba 2004, Yang 2004). A key common result is that the impact of migration and remittances is not homogenous across sub-groups of children with particular demographics. In particular, the positive impact on education outcomes tends to be larger for girls, younger children, and children whose parents' (particularly mothers') schooling is low. Hanson and Woodruff (2003), for example, find that in rural Mexico, living in a migrant household results in girls aged 10-15 completing significantly more years of schooling in the case where the mother has a low level of education. Consistently, McKenzie and Rapoport (2011), by using historic migration as an instrument, find that Mexican children aged 16 to 18 in migrant households have lower levels of educational attainment especially for children whose mothers have higher levels of schooling. Among the explanations they offer is that children at that age may start migration and hence quit school. In addition, migration may create a disincentive to remaining in school as the returns to education in Mexico are higher than in the USA leading to lower education aspirations for those planning to migrate.

Only few papers examined the impact of migration and remittances on child work, and none of them look at the labor market effects. Yang (2008), for instance, find that remittances received at the household level reduce the labor supply of children aged 10-17. The outcome used by the author is the change in total hours worked and changes in hours worked in different types of employment. He find that the exchange rate shock (proxying for remittances) has a negative effect on total child work hours. Looking at employment types, hours worked in the category of self-employed or an employer or as a paid family farm worker, increased with the shock. Mansuri (2006) on Pakistan finds that children in migrant households are less likely to be involved in economic work and report working for substantially fewer hours.

Futhermore, according to the literature we can also expect that the link between female migration and human capital accumulation is different from that of male migration, since women's preferences as well as mothers' child supervision and monitor- 
ing of school attendance are particularly important for decisions taken over children (e.g. Hildebrandt , N. and D. McKenzie. 2005; Macours, K. and R. Vakis. 2007; Mansuri, G. 2006). Using Census data from the Philippines, Cortes (2010) finds that children of migrant mothers are more likely to be lagging behind in school compared to children with migrant fathers. Findings are robust to controlling for gender differences in remittance behavior, supporting the hypothesis that mother' absence has a stronger detrimental effect than father' absence.

Finally, other studies have pointed out that many working children in low income countries are employed in the family business, most often on the farm (especially in Africa), and missing or imperfect labor markets lead to child labor persistence even among the wealthiest households (Bhalotra and Heady, 2003; Bhalotra, 2003). Moreover, the majority of children typically work in the household itself, looking after siblings or substituting for adult members in the perfomance of domestic works or chores (Cigno, Rosati and Tzannatos, 2001). There is a limited but consistent amount of evidence on the effect of increases in local labor demand on children's time allocation and labor supply in developing countries (Manacorda and Rosati, 2010; Parikh and Sadoulet, 2005). Thus, in poor economies, where the market for hiring labor is likely to be affected by significant labor force outflows, migration of adults may have unclear consequences to the child labor resolution problem. We focus on this ambiguity exploring the determinants of different forms of child labor -within and across countries- and their interaction with the labor-market impact of international migration, by skill and gender, on sending regions.

\section{The data}

Our empirical analysis is based on a cross-country household survey data set coupled with country-level information on international migration flows from a large set of developing countries. The former is the Multiple Indicator Cluster Survey at the end-decade assessment (MICS II), an international household survey initiative led by UNICEF that provides internationally comparable micro-level information on child labor and schooling for 38 developing countries- 22 of which in Africa, 8 in Asia, 5 
in Latin America, 3 in Eastern Europe. Most of the MICS II were implemented in 2000 (with a few countries in 2001) and contain several household level information, such as demographic characteristics, wealth indicators and education information on household's members. The most important feature of this dataset is that it containes homogeneous data on both domestic and market labor participation of children, where the latter are individuals aged 5-15. Labor activities include market work, family's business work and general domestic activities.

The data source for international migration is the recently developed database produced by Docquier, Marfouk and Lowell (2007), which contains estimates of emigration stocks and rates of the working-age population (aged 25 or more) from 195 source countries to OECD countries in 1990 and 2000. The advantage of this dataset, whith respect to others, is the disaggregation of migration flows by country of origin, skill (i.e. educational attainment) and gender. ${ }^{5}$ Three levels of schooling are distinguished in the dataset: low-skill workers are those with primary education $(0$ to 8 years of schooling completed), medium skilled workers are those with secondary education (9 to 12 years of schooling) and high-skilled workers are those with tertiary education (13 years and above). Information about the skill and gender of the native labor force is also available. ${ }^{6}$

We further combine the latter macro-data with country-level information on remittance inflows in 2000, drawn from the World Bank's estimate based on the International Monetary Fund's Balance of Payments Statistics Yearbook 2008. Yet, information on remittances are only available for 28 countries among those for which we have individual level information.

For each of the 38 countries we include in our analysis, Table 1 illustrates the

\footnotetext{
${ }^{5}$ The other advantage of using this dataset with respect to others is that data are from national censuses which tend to be more representative, more accurate and more complete than other data sources. Censuses (i) often account for undocumented immigrants at least in some countries like the US, (ii) they categorize immigrants by place of birth, rather than nationality which can change over time and across countries due to naturalization laws and (iii) report their education levels (see Docquier, Lowell and Marfouk, 2008, for futher details).

${ }^{6}$ The fact that it is not possible to distinguish migrants that did not complete primary education or with no education at all from those with completed primary education is a data limitation, since there is a lot of variation with respect to the latter categories in many developing countries. Moreover, according to the data construction we are not able to distinguish the country in which each individual received her education, but according to Beine et al. (2007) controlling for age of entry does not lead to different estimates of the educational level of the stock of emigrants.
} 
incidence of child labor (i.e. children employed in any work activity), total emigration rates as a proportion of the total labor force born in the sending country (including migrants themselves), unskilled and skilled migration rates (i.e. the ratio between the emigration stocks by educational attainment to the total number of people born in the source country and belonging to the same educational category), an index that measures the share of unskilled migrants as a proportion of the share of the unskilled labor force (see below) and finally the level of remittances as a percentage of the country GDP.

-Table 1 about here-

Key in our study, we use different measures of out-migration flows as they differently reflect the pressure they impose on the local labor market. Measuring the migration rate by educational attainment as a proportion of the total labor force in the same educational category is a well used strategy to do so (Docquier et al. 2007). Yet, a direct approach to measure the emigration-induced labor market competition entails measuring the relative skill composition (RSC) of emigrants with respect to the total labor force at origin. Hence, we build the RSC index $\left(\frac{m_{j}^{\text {low }}}{1-m_{j}^{\text {low }}} / \frac{l f_{j}^{l o w}}{1-l f_{j}^{l o w}}\right)$, that is the ratio of low-skilled to skilled labor in the migrant relative to the stayer populations in country $j$ (see Mayda, 2006). The higher is the latter index, the lower is the skill composition of emigrants with respect to stayers. The advantage of the RSC index is that it considers not only the outmigration skill composition, but also the resident labor force skill composition, and therefore it is a proxy for changes in relative wages induced by migration.

Table 1 shows that the share of children involved in any work activities (both on the market and at home) is quantitatively important in all of the countries considered and variability spans from a minimum of $15 \%$ to $92 \%$. On average the migrant population is around $3 \%$, even if for some countries it is equal or greater than $20 \%$. Based on both the skilled-migration share and the RSC index, in all countries out-migration is more skilled than the resident labor force. Yet, there is great variation, namely for some countries either the share of unskilled migrant population is relatively high 
or the share of unskilled labor force is relatively low. Column (5) reports remittance rates as percentage of the GDP and it is worth noting that for Albania, Moldova and Lesotho remittances in 2000 are a substantial source of income, reaching respectively 16, 14 and 34 percentage of the GDP.

Combining these two sources of micro and macro-level information, we assembled an original data set for 38 less developed countries where both child labor and outmigration are relevant phenomena. In this way we include in the analysis more than 200,000 children aged 5-15.

Based on survey data, Table 2 reports descriptive statistics of main characteristics of children and their families. On average, relatively older children, females, those living in rural areas and having larger family size work more frequently, while those who live with their own mother work less. Moreover, the share of working children is higher at the lower quantiles of the wealth distribution, where the latter measures households' socio-economic status based on individual/household assets ownership. Most of the surveyed kids are employed in some work activities (73\%) and domestic work is prevalent ${ }^{7}(68 \%)$, followed by market work (32\%) and family business $(26 \%)$. It should also be noted that school attendance is relatively high, as $81 \%$ of the kids declared to have attended school during the last year. ${ }^{8}$ The different work activities and school attendance are not mutually exclusive though, with $63 \%$ of children engaged in both.

-Table 2 about here-

In Figure 1 we report the scatter plot of the correlation between country-level incidence of child labor and the RSC index. Correlation is negative, i.e. the higher is RSC the lower is the share of children involved in work activities. This may suggest that, consistently with the theory, the lower is the skilled composition of emigrants relative to stayers, the bigger is the ex-post supply shock of unkilled relative to skilled workers in the origin economy, the higher (lower) is the low-skilled (skilled) wage, and

\footnotetext{
${ }^{7}$ Chores include fetching wood or water, caring for children, cooking, shopping, cleaning, whashing clothes, etc.

${ }^{8}$ Yet, the quality of such a variable may be poor in that unable to capture the intensity of school attendance or achievments.
} 
therefore the higher is the income of low-educated families. If child labor is negatively affected by the latter, then children's labor supply is negatively associated with lowskilled migration outflows. In the rest of the paper, using individual level data, we investigate how children's labor supply determined by their parental skill level - as a proxy of labor market conditions - interacts with the (relative composition of) migration outflows from the country they live in. We further control for remittances, as the latter may also play a role on child labor by increasing income of low-killed families.

-Figure 1 about here-

\section{Empirical Strategy}

We start by estimating a child labor equation in order to investigate the individuallevel determinants of children's labor supply within countries with different emigration flows. The empirical model is a linear specification as follows:

$$
Y_{i j}=\alpha_{0}+\alpha_{1} X_{i j}^{\prime}+\alpha_{2} H_{i j}+u_{j}+\varepsilon_{i j}
$$

where $Y_{i j}$ is a dichotomous variable indicating whether child $i$ in country $j$ supplies any kind of work. We first take into account generic labor supply, then we distinguish between market and domestic work. We further use hours of work as a continuous dependent variable. In a last specification, we test a school enrollment equation by using whether the child attended school in the last year as dependent variable, even though the latter does not exclude labor supply. $X_{i j}$ is a vector of individual and household-level characteristics typically shaping child labor, including age, gender of both the child and the household head, a dummy indicating whether the child ever attended school, two dummies for living with the mother and the father, family size and household demographics, birth order, a dummy for urban area and the wealth index in quintiles (summary statistics for these variables are reported in Table 2).

$H_{i j}$ is a key variable that measures the skill level of child $i$ 's household head, characterized by her/his educational achievement. The latter is a proxy for individual 
wages that enablies us to identify the household head's labor market unit. In most of our specifications, $H_{i j}$ is a dummy variable equal to one if the household head is low-skilled, i.e. has primary education vs secondary, tertiary and others, as to match the same classification of educational attaiments as reported in the countrylevel migration dataset (in other specifications we also use alternarive variables for educational attainment, e.g. college education vs non-college education). $u_{j}$ are country fixed effects and $\varepsilon_{i j}$ is the error term. In the estimation we allow for spatial correlation, clustering the errors at the country level.

Yet, in general cross-country coefficients may not be homogenous and, in particular, parental skill levels may have a different impact on child labor across countries with different emigration rates via a labor market effect. Therefore, in order to test the latter hyphothesis, we take advantage of the panel data structure of our combined dataset (children within country) and estimate a child labor equation in which we explore the heterogeneity of individual-level variables across economies with different emigration flows. Hence, we estimate an individual level model with country-level fixed effects, and test for interactive effects between individual (parental) characteristics and country-level covariates, as follows:

$$
Y_{i j}=\alpha_{0}+\alpha_{1} X_{i j}^{\prime}+\alpha_{2} H_{i j}+\alpha_{3} H_{i j} * m_{j}+u_{j}+\varepsilon_{i j}
$$

where $m_{j}$ is a measure of the emigration supply shock in country $j$. The direct effect of the variable $m_{j}$ is perfectly absorbed by the country fixed effects. Our coefficient of interest is $\alpha_{3}$, which captures the labour market impact of the emigration shock on child labor supply within relatively low-educated households.

Given the focus of our analysis, as already mentioned in the section on data description, we characterise the migration variable $m_{j}$ in different ways in order to better capture the emigration-induced pressure on the local labor market, which on turn may affect child labor. Indeed skilled and unkilled workers (as well as female and male workers) do not compete in the same market so that we focus on the skill composition of emigration as to explore whether the impact of parental skill on child 
labor takes place through a local labor market effect. Thus, in first place we distinguish the migration rates by educational attainment of migrants (as a proportion of the total labor force in the same educational category) and we include as regressors the country-level fractions of migrants with primary education (which is absorbed by the fixed effects), as well as the interaction term with the individual low education variable.

Secondly, and most importantly, we can measure the labor market impact of emigration by taking into account also the skill composition of resident workers. Therefore, we can model the effect of parental skill on child labor as a function of each country's relative skill mix. To do so, we include in the empirical specification both the country-level RSC index (which is absorbed by the fixed effects) and the interaction variable between the individual skill level and RSC. We do the same by additionally differentiating migrants by gender and by matching individuals and migration rates according to both skill level and gender, in order to identify even better labor market units.

In addition, all empirical specification are further amended by including the level of remittance inflows (as a percentage of the GDP) at the country level, and the interaction term between the latter variable and the individual (parental) skill level, as a proxy for a 'pure' income effect.

The emigration variable is assumed to be exogenous in the basic model. This is so as migration variables are based on data on migration stocks which are likely to reflect the cumulative flow of permanent and temporary workers over past decades as reflected in 2000. Thus migration stocks variables are more appropriate to measure migration dynamics with respect to flows (Docquier and Marfouk, 2006). It follows that the most relevant determinants of the migrant stocks reported in the Docquier et al. (2007) database are likely to reflect economic and other conditions prevalent in periods earlier than 2000, which reduces endogeneity concerns of migration with respecto to child labor in 2000. Furthermore, we investigate both interacted and heterogenous effects which helps confirming identification, since any omitted variables would have to behave differently for different slices of the data in order to exhibit 
the sorts of heterogenous effects that we find. However, we do an attempt to further reduce endogeneity concerns by using both the variation in net emigration flows during the 1990s and the lagged (ten-years before) migration variables.

\section{Results}

\subsection{Individual-level determinants of child labor}

We start by reporting individual level determinants of children's labor supply in Table 3 and results show the expected sign. In particular, children whose household head is relatively low educated (i.e. primary school education vs higher education) are significantly more likely to supply labor of any kind (market, family business work, chores) and less likely to attend school. Education is a typical proxy for earnings as low-skilled household heads are likely to face worse labor market conditions which are strongly associated with child labor in our cross-country sample of children. ${ }^{9}$ Moreover, being relatively older increases the probability to supply work and males are more frequently employed in market work, while females are significantly more engaged in domestic works (chores). Male headed households, on the other hand, are significantly more likely to send children to work.

-Table 3 about here-

Overall, it seems that more disadvantaged households are more likely to dispatch their children to work. This is so as, on average, children living in rural (urban) areas are positively (negatively) associated with labor supply of any kind. Moreover, the lower the level of wealth of the child's family, the higher is the probability of child labor. As far as household demographics are concerned, results of their influence on the incidence of child labor are as expected. The number of siblings under 5 years old is positively associated with the propensity to work and negatively associated with

\footnotetext{
${ }^{9}$ It has been also shown that education is likely to be trasmitted across generation, and the sensitivity of the latter trasmission (the gradient) is higher in low-income settings. This is important to us because our results will point to a country-level variable/policy (i.e. migration) which may reduce such a gradient.
} 
school attendance. In households where there are many female adults, instead, the probability to work (especially in chores) is lower.

Finally, our regression specifications always control for the presence of either the mother or the father in the family, which is a catchall variable for any form of parental absence, including migration. Results show that if the mother lives at home, the child probability to supply labor significantly decreases while school attendance significantly increases. Fathers' presence instead seems to play little or a positive role in favouring child market or family business work. These findings are consistent with 'traditional' gender roles within the family with respect to investment in children, even though we cannot explore further this aspect in this context. What is important to us, though, is that the dummy variables for whether the mother or the father is present at home allows us to control for whether there is a case of maternal or paternal emigration in the household.

In the next section we allow for cross-country heterogeneity of coefficients according to different levels of international migration out-flows.

\subsection{The role of out-migration on child labor supply}

In the benchmark model above we constrain the coefficients on individual characteristics to be the same for all countries in our sample. Yet, socio-economic determinants of child labor may differ across economies. In particular, according to the theory discussed above, the effect of parental skill on child labor may take place in the labor market. Thus, we take advantage of the panel structure of our data (children within country) and investigate whether the skill level effect is heterogenous across countries with different levels of labor migration outflows. We estimate equation (2) above, where we focus on both low-skilled households (measured by a dummy variable equal to one if the household head has no more than primary education) and the interaction term between parental low-education and the emigration supply shock.

In order to measure the latter, in a first specification we use the (log of the) aggregate rate of emigration with respect to the total resident population. Results reported in Table 4 show that, ceteris paribus, the relationship between the parental 
skill level and child labor depends on the emigration rate. Indeed, the emigration supply shock negatively affects the probability to work of children with low-educated household heads, thereby offsetting or mitigating the positive direct effect of parental low-skill on child labor. According to our estimates, a 10\% increase in the migration rate decreases the probability of child labor by 1.2 percentage points (p.p.) and the total time of weekly work by 7.3 hours. The latter effect holds for child domestic work while there is no impact on market or family business work. In addition, the migration effect is significantly positive when the dependent variable is school attendance in the last year. ${ }^{10}$ In Table 5 we check the robustness of our results to the inclusion of the (interacted) remittance variable, the availability of which reduces our sample by 10 countries. ${ }^{11}$ Thus, in the odd columns of the same table we also report migration estimates by using the same reduced sample of 28 countries and results do not show remarkable differences with respect to the case with the largest sample. On the other hand, the migration effect is robust to the inclusion of the (interacted) remittance effect at the country level.

-Table 4 and 5 about here-

We may interpret the negative effect of migration on child labor in the relatively uneducated group of households in terms of the labor market response to supply shocks. Emigration shifts labor supply in the local labor market unit in the country of origin, thus pushing wages up. From a theoretical perspective this may have an ambiguous effect on child labor. On the one hand, assuming that children and adults are substitute workers to some extent, incentives to work are stronger as earnings are higher. On the other hand, the increase in adults' wages may prevent child work, as adults themselves can provide to the income that was generated by children. Remittances, as well, as a proxy for aggregate income inflows, may play a role in reducing child labor. However, the measure for remittances we use is not at the household level, but it is a country-level indicator of official private capital

\footnotetext{
${ }^{10}$ When we use hours of work as dependent variable, we loose some observations. When we estimate the 'school attendance' equation we loose about 80.000 observations due to missing observations in such a dependent variable.

${ }^{11}$ For the seek of space, we only report linear results of the child probability to work. Results on hours of work are available from authors upon request.
} 
flows, which are likely to underestimate remittances sent, especially from and to loweducated households, through informal or unofficial channels. This is also likely to be the explanation of the small coefficient we find on the correlation between remittances and labor supplied by children with low-skilled parents (Table 5). School enrolment is consistently positively related to migration outflows in low-educated households but when remittances are considered the effect is no more statistically different from zero. As a robustenss check we further control for the interaction between low-skilled parent and the national GDP per capita, in order to capture the (indirect) effect of unofficial remittances. In addition, we amended our child labor estimating equations with cohort-country fixed effects (by interacting child age and country dummies), as to clean out the impact of cyclicality. In both cases findinds are not siginifcantly different from the ones presented in Table 5 (results are availble upon request).

As already discussed throughout the paper, though, the degree to which outmigration put pressure on the local labor market is likely to be correlated with the skill composition of both the emigrant and resident population.

In oder to tackle this issue, in a next specification we replace our aggregate migration rate indicator with the (log of the) percentage of emigrants with no more than primary education as a proportion of the total labor force in the same educational category. The latter is a better measure of the labor supply shock in the specific (low-skilled) local labor market unit. Results in Table 6 are similar in terms of significance to the previous ones and they all point to a negative correlation between unskilled emigration and child labor in low-educated households. There is also evidence of a significant positive correlation between low-skilled emigration and child school enrolment in similarly low-skilled households. The magnitude of coefficients is higher though, suggesting that what drives the negative correlation between migration and child labor in low-educated households is the migration rate of the unskilled labor force, that is the labor market competition within skill group. Same estimated effects are robust to the inclusion of remittances (results not shown and available upon requests).

-Table 6 about here- 
The latter findings seem to confirm the market mechanism we are putting forward to explain the relationship between child labor and out-migration. The labor market competition takes place within skill groups and, given that children in low-educated families are more likely to work, they are also those who benefit more from a relatively less skilled emigration shock through a positive effect on the local labor market and hence on adults' wages.

\subsection{Empirical evidence using a direct measure of the skill composi- tion of emigrants relative to residents}

In order to measure the relative skill composition of emigrants, while taking into account the skill composition of stayer workers as well, we use the RSC index (see detailed descritpion above) as a better and more direct measure of the emigration supply shock. It is worth recalling that according to our RSC characterization, the higher is the index the lower is the skill composition of emigrants with respect to the resident population. Here the RCS index is the log of 1 plus the skill composition of emigrants relative to stayers.

Results reported in Table 7 show that the less skilled emigration is relative to stayers, the less likely children are to work in any activity, i.e. market. family business and chores. The amount of hours of work supplied by children decrease as well upon the low-skilled emigration supply shock. The estimated effects are lower in magnitude than before but more precisly estimated as they are significant at $1 \%$ level. After controlling for remittances though (Table 8) effects on the probability of market and family business work are still negative but in some cases less precisely estimated, while the coefficients of total and domestic work are robust.

-Table 7-8 about here-

We interpret these results as evidence that emigration may affect child labor through a labor market competition effect. This is so as RSC is a more precise index of the emigration-induced pressure on the local labor market (see Mayda, 2006). Accordingly, when the skill composition of emigrants relative to stayers is lower, the 
labor market competition for unskilled local workers is lower and so their wages will be higher. Thus, our results suggest that children will benefit from this effect by decreasing their likelihood and intensity to work, especially in domestic activities. On the other hand, on average there is no evidence of a dominating substitution effect between child labor and low-skilled adult work.

As a robustness check, we further explore how children of skilled parents respond to emigration in the same skill group. We hence specify the same model as above by using a different RSC', that is the ratio of high-skilled (i.e. college educated) to lowskilled labor in the migrant relative to the stayer populations and by interacting RSC' with an indicator for whether the household head is skilled (i.e. he/she has tertiary education or more). The higher is RSC' the more skilled emigrants are relative to stayers. Results are reported in Table A1 in Appendix and show that within skilled households child labor negatively responds to the labor market competition associated with skilled migration, even though the effects are little precisely estimated (the only barely significant effects are the ones on hours of market and family business work) and the magnitude of the coefficients is much smaller than it is the case among children of low-educated parents. Thus, the labor market shock induced by changes in the supply of college educated workers seem to have little or no effect on labor supply among children of skilled parents. This may reflect the fact that the latter are less likely to be affected by the 'need' of child labor, or alternatively that emigrationinduced income gains are relatively smaller in the skilled labor market than it is the case in the low-skilled unit (i.e. more advantaged people have a relatively lower elasticity of labor supply).

As a falsification test, in two different specifications we explore how children of parents with a given level of skills respond to the emigration shock in a different skill group. Thus, we use the same equation as above but testing (i) whether the correlation between parental low-skill level, measured by primary education, and child labor is affected by the relative high-skilled composition of emigrants measured by the RSC' index; and (ii) whether the correlation between parental high-skill level, measured by tertiary education, and child labor is affected by the relative low-skilled 
composition of emigrants measured by the RSC index. Findings are reported in Table A2 and A3 in Appendix respectively. As expected, results are less significant than above, but where there is an effect, the latter seems to point to a positive direction. In particular, children of low educated parents are little or no affected by RSC', but the correlation between the latter and labor supply (especially chores) among children of low educated parents is positive. On the other hand, RSC' has a negative, albeit non-significant effect, on child schooling, suggesting the little role played by skilled migration in increasing incentives to go to school (Table A2). Similarly, children of highly educated parents are slightly positively affected by the emigration supply shock in the low-skilled market, especially with respect to market labor supply in and out of family businesses (Table A3). This may reflect the fact that the emigrationinduced shortage of skilled labor (unskilled labor) tends to lower relative low-skilled wages (skilled wages), and the latter may push child labor through a negative income effect. Moreover, the prospect of future migration, when it is mainly low-skilled, seem to significantly lower the incentive to invest in child education (see McKenzie and Rapoport, 2011). ${ }^{12}$ The latter evidence altogether can be considered as a symptom that outmigration does affect child labor through a labor market effect.

\section{Heterogenous results}

It is now interesting to consider the same estimation models as above on different sub-samples in order to explore if children's labor supply is differently shaped according to their attributes such as the place where they live (urban vs. rural areas), their age, gender or family wealth status. This is so as labor market returns and conditions may differ across contexts and individual attributes. For instance, older children may be more responsive to incentive to work as substitutes of (low-skilled) adult labor, while younger children may be more (economically and non-economically) dependent

\footnotetext{
${ }^{12}$ Our findings are in part consistent with recent evidence on the labor market effects of emigration in OECD countries provided in Docquier et al. (2011). By simulating the long-run employment and wage effects of emigration, the latter study shows that emigration of mostly college-educated workers has a significant negative impact on the wage of less educated non-migrant workers through the forgone complementarity effects and lost of externalities from the departure of highly educated natives.
} 
on parental conditions. We also consider separately female and male migration rates and female and male labor market units as to explore if children's time allocation differently respond according to gender-specific migration. This is a relatively unexplored and relevant issue since the feminization of migration outflows is an increasing phenomenon (Docquier et al. 2007).

\subsection{Migration effect by individual and household characteristics}

Results in Table 9 show that child labor in both rural and urban areas is responsive to changes in the migration skill composition. Yet, results on market and family business work are more precisely estimated for urban children whilst coefficients of both generic and domestic work are slighty higher in the sub-sample of children living in rural areas. This may reflect the fact that rural labor markets in developing countries are more competitive such that the emigration-induced wage gain is lower than in urban areas. At the same time though, children in rural families may be more sensitive to labor market incentives as their work is typically a buffer for other (land and labor) market imperfections as well as a complementary input to agricultural assets (see Bhalotra and Heady 2003). ${ }^{13}$

-Table 9 about here-

Heterogenous effects may be also expected with respect to child age and gender. Table 10 reports results on children aged 5-9 and 10-15 separately. The interaction effects on the child labor propensity and intensity are higher and more precisely estimated for the sub-sample of youger children, suggesting that the latter are those who benefit more from out-migration via a labor market effect. Indeed, when outmigration is relatively less skilled than the local labor force, younger children of loweducated parents are less likely to be involved in any work activities (especially out of home) and more likely to go to school. In other words, when parents are favored by better labor market conditions, they withdraw their younger children out of the labor

\footnotetext{
${ }^{13}$ It should be noted that the average incidence of child labor in market work activities is 10 p.p. higher in rural than in urban areas- while the incidence of child work in chores is about the same across the two areas.
} 
force. Older children instead are less affected by the parental skill-RSC interaction which is not statistically significant, with the exception of the case of chores. This may be due to the fact that older children are more likely to be sensitive to labour market returns and to substitute unskilled adult work. Under certain assumptions, the estimates for older children can also be considered as a sort of falsification test. Indeed, if older children's labor supply decisions are less affected by their parents' decisions or conditions ('life-course hypothesis', Shavit and Blossfeld 1993), finding an effect of parental skill-outmigration interaction in the age group 10-14 as large as the one in the 5-9 age group would be considered as a symptom that we are catching a spurious correlation.

-Table 10 about here-

Table 11 reports heterogenous migration results by child gender. While the average estimated migration effect is almost the same across males and females, there is a stronger compositional effect on the male sub-sample. Higher relative low-skilled emigration leads to a reduction in boys' labor supply in market, family business and household work, while the impact on female children is almost entirely driven by the reduction of family work. This is also consistent with expectations.

-Table 11 about here-

Finally, in Table 12 we report heterogenous migration effects across poorer and richer households, defined according to their level of wealth being in the bottom two or the top two quantiles of the wealth index distribution respectively. Not surpringly, results point to a stronger emigration effect among children in poorer householdseven though there is some evidence of the labor market effect of emigration on richer children as well (see Bhalotra and Heady 2003).

All of the above heterogenous effect are always robust to the inclusion of remittances (results are not shown and available upon request).

-Table 12 about here- 


\subsection{Emigration, skill and gender}

We now explore heterogenous effects in children's labor supply according to both the gender of emigrants and the gender of the household head. Even though female migration is relatively unexplored in the literature, migration of women raises important concerns with respect to investment in future generations' human capital (Cortes, 2010). This is so because of the growing roles of women as economic agents and their preferences for investing resources in child well-being (Thomas, 1990). While there are differences in children's outcomes according to whether migration is a female or male dominated process, these differences even vary with the gender of the parent /household head, once again because of gender-specific prenferences over children's time use.

Moreover, by considering two key individual (parental) attributes such as gender and skill, we are able to better indentify the labor market units potentially affected by gender-skill specific emigration shocks. If males and females compete on different labor markets, then female (male) out-migration flows may directly affect female (male) conditions and hence we may observe a differential impact on child labor supply by the gender of the parent.

We estimate a child labor equation on different sub-samples, namely the full sample, the sample of children with a female household head, the sample of children with a male household head, by using as a key regressor the gender-specific RSC index. ${ }^{14}$ Results on female and male out-migration shocks are reported in Table 13 and Table 14 respectively.

-Tables 13 and 14 about here-

Results show that on average child labor is slightly more responsive (in terms of magnitude of coefficients) to female than to male out-migration, for both generic and domestic work (reults panel A in Table 13 and 14). This may be due to the fact that women typically face less favourable labour market conditions and therefore

\footnotetext{
${ }^{14}$ The gender-specific RSC index is $\left(\frac{m_{i j}^{\text {low }}}{1-m_{i j}^{\text {low }}} / \frac{l f_{i j}^{\text {low }}}{1-l f_{i j}^{\text {low }}}\right)$, that is the ratio of unskilled to skilled labor in the migrant relative to the stayer populations of gender $i$ in country $j$, where $i$ is equal to either female or male.
} 
they benefit relatively more at the margin, in terms of earnings and well-being, when female outmigration reduces labor supply (i.e. female labor supply is more elastic).

Gender differentails, though, are even more marked when we look at households with either female or male household head separately, and therefore when we match gender-specific emigration shocks with individual/household characteristics.

On average, results are bigger and more significant when we estimate the child labor effect on homogenous labor market units on the basis of both household's skill and gender. Indeed, low-skilled female out-migration has a stronger effect on child labor in low-skilled female headed households rather than in households with a male head (Table 12, panel B and C). The effect of male out-migration instead is not very differently shaped according to household's gender (Table 13, panel B and C). Overall, these results show that adult men and women do not compete in the same labor market and that the labor market impact of emigration in countries of origin is indeed at work in shaping the work supply of children as well. ${ }^{15}$

In particular, after controlling for the presence of the mother in the household, we find that children are significantly less likely to work the higher is the female outmigration shock in the local labor market - especially in female headed households. This is consistent with other evidence showing that more disadvantaged groups (such as women with respect to men, on average, or less educated adult women compared to skilled ones) are especially responsive to new 'market opportunities' made available by the opening of the borders - and that women invest more than men in children's human capital (e.g. Mushi and Rosenzweig, 2006; Luke and Munshi, 2007). All results are robust to the inclusion of remittances (results available upon request).

\section{Robustness checks}

Our empirical analysis above is based on a well-used database of migrant stocks collected in all OECD destination countries in 1990 and 2000, using census data as

\footnotetext{
${ }^{15}$ Still, there is some evidence of complementarities between female and male labor supply, as shown by some significant results in Table 12-Panel C and Table 13-Panel B.
} 
primary data sources, and disaggregated by education level, gender and country of origin (Docquier and Marfuk, 2006, and subsequent revisions). The latter migration dataset has several advantages, as outlined in the Data section above, but at the same time it may be under-reporting low-skilled migration flows since emigration to OECD countries is particularly high-skilled with respect to the non-migrant native population (see also descriptive statistics above). Thus, in order to increase the percentage of south-south migrants we use two different sources of migration data, namely the recently updated version of the Docquier and Marfouk (2006) database by Docquier, et al. (2010) and the World Bank Global Bilateral Migration Database. The former supplement original data by expanding the number of receiving countries used to calculate migration stocks by country of origin, i.e. by adding the censuses of 46 new non-OECD receiving countries for the period 1990 and $2000 .{ }^{16}$ The WB database instead is based on a combination of both censuses and population register records which allows us to construct the stock of emigrants for each of the countries included in our analysis. Thus both these datasets have the advantage that they include at least some non-OECD destination countries, such that they are likely to better capture the 'low-skill intensive' emigration. At the same time, though, both datasets do not provide the breakdown by education level of emigrants such that we are not able to analyse the skill composition and the labor market impact of emigration. ${ }^{17}$ Nevertheless, in Table 15 we report regression estimates while using the (log of the) aggregate rate of emigration with respect to the resident population in 2000 as measured in the recent Docquier et al. (2010) database. Results are similar to those reported in Table 4, even though the effect of emigration on child labor is generally more precisely estimated in all of the different child labor equations (columns 1-8). On the contrary, school attendance equation is estimated with less precision (column 9). Thus, extending the coverage of the Docquier et al. (2008) database to some non-OECD countries leads to the same finding as above, namely

\footnotetext{
${ }^{16}$ The inclusion of 46 non-oecd countries is an improvement with respect to our main dataset but still give a biased measure of out-migration, as it leaves out many important destination countries (such as India, Russia, Serbia, Ukraine, Egypt, Congo, Ghana, etc.)

${ }^{17}$ Actually the Docquier et al. (2010) database disaggregates emigrants by skill, but unfortunately it only accounts for those with at least some post secondary education vs. all the rest.
} 
that the emigration supply shock is negatively associated to child labor within lowskilled households.

-Tables 15 about here-

In Table A4 in the Appendix we report regression estimates while using the (log of the) World Bank aggregate rate of emigration with respect to the total resident population in 2000 as a measure of the country-level migration shock. Results are consistent with what we found above- in particular, the interactive effect is more precisely estimated for chores, while the effect on child school attendance is again positive and significant.

It would be interesting to explore further how the emigration of such 'more comprehensive' pool of workers shifts the relative composition of non-migrant workers of different education level, but as already mentioned data constraints do not allow such an analysis. However, results obtained using different data sources confirm the positive impact of emigration on child labor reduction.

Another concern related to the robustess of our results is that up to now we have assumed that the emigration variable is exogenous. This is so as migration variables are based on data on migration stocks which are likely to reflect the cumulative flow of permanent and temporary workers over past decades as reflected in 2000. The implication is that the most relevant determinants of the migrant stocks reported in the Docquier et al. (2007) database are likely to reflect economic and other conditions prevalent in periods earlier than 2000, which reduces endogeneity concerns of migration with respect to child labor in 2000 .

Nevertheless, in what follows we present some of the same estimated child labor equations as above while replacing our stock-based emigration variables with either (i) country-level emigration flows in the 1990s or (ii) lagged (10 year before) emigration stock variables. The data source for international migration is the same as in the previous section (Docquier, et al. 2007) as it contains skill-disaggregated estimates of emigration stocks and rates in 1990 as well as in 2000 .

Thus, by using the stock of emigrants (and local labor force) for each country in our sample in two different years (1990 and 2000) and taking the difference between 
the two, we get the relevant net emigration flows to be used in our analysis. Focusing on the variations in the flow of emigrants over time allows us to net out returnees from the gross flows of emigrants and possibly to better isolate the specific shortrun effects of emigration (see Docquier et al. 2011). Results are reported in Table 16 and 17, where we use as key (interactive) regressors the net emigration outflow in the period 1990-2000 divided by the initial labor force population, and the net outflow of low-skilled (primary-school educated) emigrants relative to the similarly educated resident population in the 1990, respectively. Interestingly, we find no different results from the ones obtained while using emigration stocks in 2000, both in terms of significance and magnitude. Moreover, we calculated the flow-based RCS index and results reported in Table 18 confirm the negative impact of the lowskilled emigration outflow composition relative to stayer on child labor likelyhood and intensity.

-Table 16-18 about here-

As a futher robustness check, we replace the emigration stock in 2000 with a lagged well-behaved variable, namely the 1990 emigration outflow. The latter captures the 10-years before emigration supply shocks which is unlikely to be related to unobservables that may simultaneously determine both migration and child labor in 2000. In this way we mitigate reverse causation problems as it is not likely that children labor supply in 2000 is a predictor for 1990 migration decisions. In order to have reverse causality in this case we should allow people in 1990 to anticipate the prospect of sending (their future) children to work in 2000 and to modify their migration decision accordingly.

Results are reported in Table 19-21. Overall, findings are consistent with those reported in the previous section and show that the (lagged) low-skilled emigration rate and composition is negatively associated with current child labor in all categories, i.e. market. family business and chores. The magnitude of the effect is smaller as the lag between the labor emigration supply shock and children's time allocation is quite large. Nevertheless, these findings confirm once again that the emigration impact 
on child labor may be at work through a labor market effect, and overall the effect of low-skilled emigration may be positive in terms of child labor reduction among children of parents with low levels of education.

-Table 19-21 about here-

\section{Conclusions}

Child labor is widespread and poverty-related phenomenon that has short- and longterm detrimental implications for individual well-being (Edmonds and Pavcnick, 2005). Globalization in general, and international migration flows in particular, may lead to a greater demand for both adult and child labor. However, the emigration supply shock in the adult labor force can raise family incomes in a way that tends to reduce child labor. Thus, wokers' mobility across national borders may have an ambiguous impact on child labour through chages in the competitive labor market.

We use an original dataset, which combines information on international migration out-flows from a wide range of developing countries with detailed individual- and household-level survey data on child labour in each country, to investigate children's work response to out-migration shocks, accounting for the skill composition of both the migrant and the resident labor force. In this way we aim at assessing the impact of international emigration on child labor through a labor market effect.

By using variation in the emigration supply shocks across labor market units defined on the basis of both geography and skill (i.e. by country and educational level), we estimate a set of child labor equations where the variable of interest is the interactive effect between individual (parental) skill and country-level emigration rates. We measure the latter in different ways as to best capture the emigration-induced local labor market pressure, namely through (i) an aggregate emigration rate in the total population; (ii) the emigration rate by skill in the same skill sub-population; (iii) the relative skill composition of emigrants relative to the resident population whereby the latter is the most direct measure of the labor market competition effect of emigration. 
Overall, our findings show that international out-migration may significantly reduce or offset the potential increase of child labor associated with low parental education, i.e. with poor labor market conditions. Indeed, ceteris paribus, low-skilled households heads are more likely to send their children to work, but this effect is strongly negative and significant the higher is the emigration rate. By decomposing the latter by skill, we show that this results is driven by the share of low-skilled emigrants out of the total resident low-skilled population.

Moreover, we use a direct measure of the emigration-induce labor market effect by using the relative skill composition (RSC) of emigrants with respect to resident workers at origin. We find that the labor market mechanism continue to play a key and robust role in child labor outcomes, after controlling for a large set of individuallevel characteristics, interactive effects of remittances, and country fixed effects. In particular, our estimates show that the cross-country variation in the correlation between parental skill and child labor is related to differences in the skill composition of emigration relative to stayers across countries of origin. Low-skilled household heads are less likely to send their children to work in countries where the relative skill composition of emigrants to residents is lower. This is to say that the labor market impact of emigration may improve children's outcomes as well.

By estimating the same equation across heterogenous sub-samples, we find that children who benefit more by the outmigration shock are younger kids, boys and children living in poorer households. Moreover, by using the labor supply shifts in education-gender groups induced by emigration, we show that on average female outmigration shocks have a higher impact on mitigating child labor, and the effect is stronger in female headed housheolds. All estimated results are robust to the use of alternative indicators of the contemporaneous emigration supply shocks such as the net emigration flows and 10-years lagged emigration stocks.

To conclude, this paper adds up to recent evidence on the labor market impact of emigration on households left behind and on the relationship between globalization, growth, and poverty in developing countries. Overall, our findings point to a significant role of international outmigration in shaping child labor in countries of origin. If 
poverty and child labor reduction are policy goals, improving labor market integration and removing barriers to international migration may deliver some development results.

\section{References}

Altonji J.G., Card D., 1991. "The Effects of Immigration on the Labor Market Outcomes of Less-skilled Natives," NBER Chapters, in: Immigration, Trade and the Labor Market, pages 201-234 National Bureau of Economic Research, Inc.

Aydemir A., Borjas G.J.(2007), Cross-Country Variation in the Impact of International Migration: Canada, Mexico, and the United States, Journal of the European Economic Association, Vol. 5, No. 4: pp. 663-708.

Baland J, Robinson J. Is Child Labor Inefficient?. The Journal of Political Economy August 2000; 108(4), p. 663-679.

Basu K., Van P. The Economics of Child Labor. American Economic Review, June 1998, 88(3), pp. 412-27.

Beine M., Docquier F., Rapoport H. (2007), Measuring international skilled migration: a new database controlling for age of entry, World Bank Economic Review, Vol. 21, pp 249-254.

Bhalotra S. (2003), Is Child Work Necessary?, Bristol Economics Discussion Papers 03/554, Department of Economics, University of Bristol, UK.

Bhalotra S., Heady C. (2003), Child Farm Labor: The Wealth Paradox, World Bank Economic Review, Oxford University Press, vol. 17(2), pages 197-227, December.

Borjas G.J. (1987), Self-Selection and the Earnings of Immigrants, American Economic Review, American Economic Association, vol. 77(4), pages 531-53, September.

Borjas G.J. (2003), The Labor Demand Curve Is Downward Sloping: Reexamining the Impact of Immigration on the Labor Market, Quarterly Journal of Economics, Vol. 118(4), pp. 1335-74.

Borjas G.J. (2008), Labor outflows and inflows in Puerto-Rico, Journal of Human Capital, Vol. 2, No. 1: pp. 32-68 
Bouton L., Paul S., Tiongson E.R. (2011), The impact of emigration on source countries wages: evidence from the Republic of Moldova, Policy Research Working Paper n. 5764, The World Bank

Card D. (2001), Immigrant Inflows, Native Outflows, and the Local Labor Market Impacts of Higher Immigration, Journal of Labor Economics, University of Chicago Press, vol. 19(1), pp 22-64, January.

Card D. (2005), Is the New Immigration Really so Bad?, Economic Journal, Royal Economic Society, vol. 115(507), pp F300-F323, November.

Cigno A., Rosati F.C. (2005), "The Economics of Child Labor", Oxford University Press.

Cigno A., Rosati F.C., Tzannatos Z. (2002), Child labor handbook, Social Protection Discussion Papers 25507, The World Bank.

Cigno A., Rosati F.C., Guarcello L. (2002), Does globalization increase child labor?, World Development 30, pp. 1579-1589.

Cortes P. (2010), The Feminization of International Migration and its effects on the Children Left behind: Evidence from the Philippines, mimeo.

Cox Edwards A., Ureta M. (2003), International Migration, Remittances, and Schooling: evidence from El Salvador, NBER WP n. w9766.

Dinopoulos E., Zhao L. Child Labor and Globalization. Journal of Labor Economics, July 2007; 25(3), pp. 553-580.

Docquier, A. Marfouk (2006) "International Migration, Remittances and Development" in C. Ozden and M. Schiff (eds). Palgrave Macmillan: New York.

Docquier F., Marfouk A., Lowell L. A gendered assessment of the brain drain, mimeo UCL, 2007.

Docquier, F., Ozden, C. and Peri, G. (2011) "The Labor Market Effects of Immigration and Emigration in OECD Countries," IZA Discussion Papers 6258.

Edmonds E., Pavcnik N. International trade and child labor: cross-country evidence. Journal of international economics, 68 (1), January 2006, pp. 115-140

Edmonds E., Pavcnik N. The Effect of Trade Liberalization on Child Labor. Journal of International Economics 65(2), 2005a, 401-419. 
Edmonds E., Pavcnik N. Child Labor in the Global Economy, Journal of Economic Perspectives, 2005b, 18(1), pp. 199-220.

Epstein G., Kahana N. Child Labor and Temporary Emigration, Economics Letters, 99(3), 2008, pp. 545- 548 .

Foster A.D., Rosenzweig M.R. (2004), Technological change and the distribution of schooling: evidence from green-revolution India, Journal of Development Economics, Vol. 72(1), pp87-111.

Grootaert C., Kanbur R. (1995), Child labour: an economic perspective, International Labour Review, Vol. 134(2).

Hanson G. The Economic Consequences of the International Migration of Labor, mimeo UCSD, 2008.

Hanson G. Emigration, Remittances, and Labor Force Participation in Mexico, Integration and Trade Journal, 2007, 27, pp. 73-103.

Hanson G., Woodruff C. (2003), Emigration and educational attainment in Mexico, mimeo, UCSD.

Heston A., Summers R., Aten B. Penn World Table Version 6.2, Center for International Comparisons of Production, Income and Prices at the University of Pennsylvania, September 2006.

Hildebrandt , N. and D. McKenzie. 2005. "The effects of migraion on child health in Mexico." World Band Policy Research Working Paper 3573. Washington DC: World Bank.

Lopez Cordoba E. (2004), Globalization, Migration, and Development: the role of Mexican migrant remittances, Econometric Society 2004 Latin American Meetings 82, Econometric Society.

Lucas, Robert E B, 1987. "Emigration to South Africa's Mines," American Economic Review, American Economic Association, vol. 77(3), pages 313-30, June.

Lucas, Robert E. B. 2005. International Migration and Economic Development: Lessons from Low-Income Countries (Cheltenham, UK and Northampton, MA: Edward Elgar Press).

Luke N., Munshi K. (2007), Social affiliation and the demand for health services: 
Caste and child health in South India, Journal of Development Economics, vol. 83(2), pp 256-279.

Macours, K. and R. Vakis. 2007. "Seasonal migration and early childhood development." World Band Policy Research Working Paper. Washington DC: World Bank.

Manacorda, M. and Rosati, F. (2010). "Local labor Demand and Child Labor" Research in Labor Economics, 31.

Mansuri, G. 2006a. "Migration, school attainment and child labor: Evidence from rural Pakistan." World Bank Policy Research Working Paper 3945. Washington, DC: World Bank.

Mayda A.M. (2006), Who is against immigration? A cross-country investigation of individual attitudes toward immigrants, The Review of Economic and Statistics, Vol. 88(3), pp 510-530.

McKenzie D. and Rapoport, H. (2011). "Can migration reduce educational attainment? Evidence from Mexico," Journal of Population Economics, vol. 24(4), pages 1331-1358.

Mishra, P. (2007), Emigration and wages in source countries: Evidence from Mexico, Journal of Development Economics, Vol. 82, pp 180-199.

Munshi K., Rosenzweig M. (2006), Traditional Institutions Meet the Modern World: Caste, Gender, and Schooling Choice in a Globalizing Economy, American Economic Review, American Economic Association, vol. 96(4), pp 1225-1252, September.

Gianmarco I.P. Ottaviano and Giovanni Peri (2011) "Rethinking the Effects of Immigration on Wages", Journal of the European Economic Association, forthcoming.

Ranjan P. Credit Constraints and the Phenomenon of Child Labor. Journal of Development Economics, March 2001; 64(1), pp .81-102.

Ratha, D.2003, "Workers' Remittances: An Important and Stable Source of External Development Finance", Global Development Finance 2003, World Bank.

Shavit Y. Blossfeld H.P. (1993), Persistent Inequality: Changing Educational 
Attainment in Thirteen Countries. Boulder: Westview Press.

Yang D. (2004), International Migration, Human Capital, and Entrepreneurship: Evidence from Philippine Migrants' Exchange Rate Shocks, Working Papers 531, Research Seminar in International Economics, University of Michigan.

Yang D. (2008), International Migration, Remittances and Household Investment: Evidence from Philippine Migrants' Exchange Rate Shocks, Economic Journal, Royal Economic Society, vol. 118(528), pages 591-630, 04. 


\section{Child Labor Migration rate}

Albania
Angola

Azerbaijan

Bolivia

Bosnia and Herzegovina

Burundi

Cameroon

Central African Republic

Chad

Comoros

Congo, Dem. Rep. of the

Cote d'Ivoire

Dominican Republic

Equatorial Guinea

Gambia, The

Guinea-Bissau

Guyana

Iraq

Kenya

Laos

Lesotho

Madagascar

Moldova

Mongolia

Niger

Philippines

Rwanda

Sao Tome and Principe

Senegal

Sierra Leone

Sudan

Swaziland

Tajikistan

Togo

Trinidad and Tobago

Uzbekistan

Venezuela

Vietnam
(\%)

(\%)

59

78

Skilled

(\%)

19

1

1

86

60

87

88

89

88

70

56

78

67

87

61

87

80

48

78

72

74

26

89

92

91

83

85

82

91

90

59

86

75

90

57

81

66

62

73

15

26
17

4

2

6

20

9

17

7

9

21

15

6

22

21

68

28

89

11

11
39

39
37

4

8

4

$$
7
$$

6

14

32

27

17

49

7

5

1

16

16
79

1

4

27

20

21

0.6

89.2
11

0.1
Low-skilled

RSC Index

(\%)

Remittances

(as \% of GDP)

$\begin{array}{ccc}18 & 0.87 & 16.22 \\ 1 & 0.74 & \\ 0.4 & 0.52 & 1.08 \\ 1 & 0.1 & 1.51 \\ 15 & 0.78 & 0.03 \\ 0.1 & 0.04 & \end{array}$

$0.1 \quad 0.04$

$0.3 \quad 0.07$

0.11

0.07

0.02

0.49

0.12

0.24

0.4

0.09

0.11

0.25

0.29

0.25

0.05

0.37

0.05

0.1

0.69

0.03

0.02

0.23

0.01

0.61

0.21

0.03

0.05

0.15

0.69

0.14

0.29

0.58

0.06

0.13

0.01

2

0.21

3.85

4

0.25

6.99

0.03

0.01

0.001

0.87

33.78

92

47

37

Note : (a) The total migration rates are the stock of emigrants divided by total population in 2000 (including migrants). (b) The skilled (low-skilled) migration rates are the stock of college (primary-school) educated emigrants relative to the similarly educated total population (including migrants). (c) The Relative Skill Composition (RSC) index is the ratio of unskilled to skilled labor in the migrant relative to the resident population. 


\begin{tabular}{|c|c|c|c|c|c|c|c|c|c|c|c|c|}
\hline & \multicolumn{4}{|c|}{ Working children } & \multicolumn{4}{|c|}{ Non-working children } & \multicolumn{4}{|c|}{ All } \\
\hline & mean & sd & $\min$ & $\max$ & mean & sd & $\min$ & $\max$ & mean & sd & $\min$ & $\max$ \\
\hline Age & 10.08 & 2.87 & 5 & 15 & 8 & 2.77 & 5 & 15 & 9.52 & 2.99 & 5 & 15 \\
\hline Male (\%) & 48 & & & & 57 & & & & 50 & & & \\
\hline $\begin{array}{l}\text { Household Head }(\mathrm{HhH}) \text { with } \\
\text { primary education }(\%)\end{array}$ & 30 & & & & 29 & & & & 29 & & & \\
\hline $\begin{array}{l}\text { Children ever been in school } \\
\text { (\%) }\end{array}$ & 72 & & & & 60 & & & & 69 & & & \\
\hline $\begin{array}{l}\text { Children living with the } \\
\text { mother (\%) }\end{array}$ & 88 & & & & 93 & & & & 89 & & & \\
\hline $\begin{array}{l}\text { Children living with the father } \\
\text { (\%) }\end{array}$ & 81 & & & & 86 & & & & 82 & & & \\
\hline Children in $\mathrm{Hh}<5$ y.o. & 2.27 & 2.01 & 1 & 10 & 2.15 & 1.66 & 1 & 10 & 2.24 & 1.92 & 1 & 10 \\
\hline Female adults in $\mathrm{Hh}$ & 2.15 & 1.78 & 1 & 10 & 2 & 1.56 & 1 & 10 & 2.11 & 1.72 & 1 & 10 \\
\hline Hh size & 8.83 & 5.2 & 1 & 30 & 8.33 & 4.53 & 1 & 30 & 8.69 & 5.03 & 1 & 30 \\
\hline $\begin{array}{l}\text { Birth order } \\
\text { Wealth index distribution }^{(a)} \text { : }\end{array}$ & 2.67 & 1.83 & 1 & 10 & 3 & 1.89 & 1 & 10 & 2.77 & 1.85 & 1 & 10 \\
\hline 1st quintile & 0.24 & & & & 0.21 & & & & 0.23 & & & \\
\hline 2nd quintile & 0.21 & & & & 0.2 & & & & 0.21 & & & \\
\hline 3rd quintile & 0.2 & & & & 0.2 & & & & 0.2 & & & \\
\hline 4th quintile & 0.18 & & & & 0.2 & & & & 0.19 & & & \\
\hline $\begin{array}{l}\text { 5th quintile } \\
\text { Children living in urban areas }\end{array}$ & 0.17 & & & & 0.19 & & & & 0.18 & & & \\
\hline$(\%)$ & 34 & & & & 43 & & & & 36 & & & \\
\hline Child labor (last week) (\%) & & & & & & & & & 73 & & & \\
\hline Child labor in market work & & & & & & & & & & & & \\
\hline$(\%)$ & & & & & & & & & 32 & & & \\
\hline Child labor in family business & & & & & & & & & & & & \\
\hline$(\%)$ & & & & & & & & & 26 & & & \\
\hline Child labor in chores (\%) & & & & & & & & & 68 & & & \\
\hline $\begin{array}{l}\text { Children attending school (last } \\
\text { year) }(\%)\end{array}$ & & & & & & & & & 81 & & & \\
\hline Children attending school \& & & & & & & & & & & & & \\
\hline working (generic work) (\%) & & & & & & & & & 63 & & & \\
\hline Total obs. & 285127 & & & & 104821 & & & & 389948 & & & \\
\hline
\end{tabular}

Notes : (a) The wealth index is a measure of household socio-economic status based on the factor analysis 
Figure 1 - Scatter plot of the correlation between country-level incidence of child labor and the RSC index

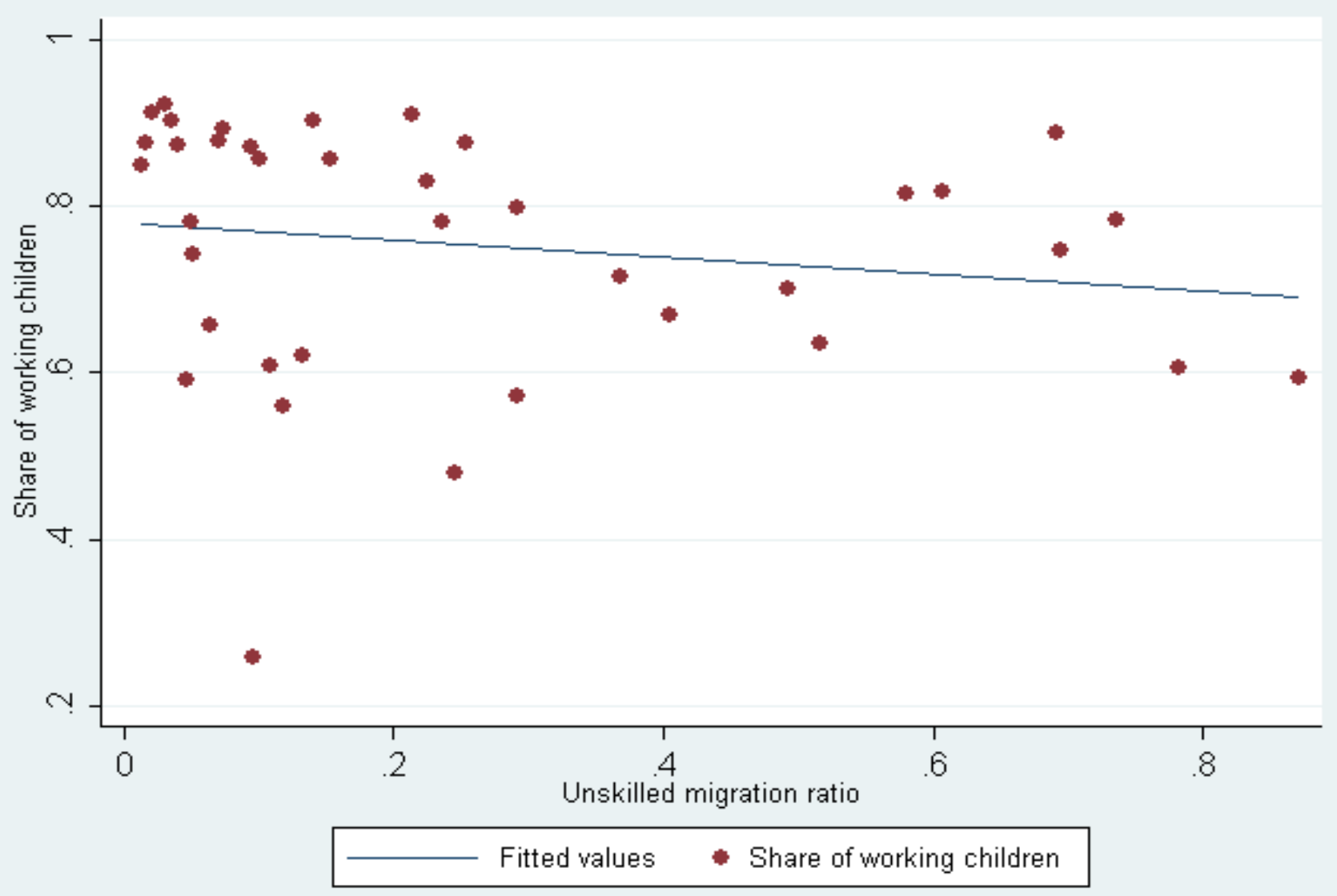


Table 3 - Individual determinants of child labor

\begin{tabular}{|c|c|c|c|c|c|c|c|c|c|}
\hline & Any work & $\begin{array}{c}(2) \\
\text { Total } \\
\text { hours of } \\
\text { work } \\
\end{array}$ & $\begin{array}{c}\text { (3) } \\
\text { Market } \\
\text { work }\end{array}$ & $\begin{array}{c}(4) \\
\text { Hours in } \\
\text { market } \\
\text { work } \\
\end{array}$ & $\begin{array}{c}\text { (5) } \\
\text { Family } \\
\text { business }\end{array}$ & $\begin{array}{c}(6) \\
\text { Hours in } \\
\text { family } \\
\text { business } \\
\end{array}$ & Chores & $\begin{array}{c}\text { (8) } \\
\text { Hours in } \\
\text { chores }\end{array}$ & $\begin{array}{c}\text { (9) } \\
\text { School } \\
\text { attendance }\end{array}$ \\
\hline HhH low-skilled & $\begin{array}{c}0.017^{* * * *} \\
(0.005)\end{array}$ & $\begin{array}{l}0.816^{*} \\
(0.446)\end{array}$ & $\begin{array}{l}0.016 * * \\
(0.007)\end{array}$ & $\begin{array}{c}0.324 \\
(0.301)\end{array}$ & $\begin{array}{l}0.018 * * \\
(0.008)\end{array}$ & $\begin{array}{c}0.120 \\
(0.247)\end{array}$ & $\begin{array}{c}0.018^{* * * *} \\
(0.004)\end{array}$ & $\begin{array}{c}0.398 * * * \\
(0.145)\end{array}$ & $\begin{array}{c}-0.028 * * * \\
(0.006)\end{array}$ \\
\hline Age & $\begin{array}{c}0.045^{* * * *} \\
(0.005)\end{array}$ & $\begin{array}{c}2.434^{* * *} \\
(0.195)\end{array}$ & $\begin{array}{c}0.033^{* * * *} \\
(0.002)\end{array}$ & $\begin{array}{c}1.020^{* * *} \\
(0.104)\end{array}$ & $\begin{array}{c}0.030 * * * \\
(0.002)\end{array}$ & $\begin{array}{c}0.764^{* * *} \\
(0.087)\end{array}$ & $\begin{array}{c}0.040^{* * *} \\
(0.005)\end{array}$ & $\begin{array}{c}1.067 * * * \\
(0.106)\end{array}$ & $\begin{array}{c}0.040^{* * *} \\
(0.003)\end{array}$ \\
\hline Male & $\begin{array}{c}-0.078 * * * \\
(0.017)\end{array}$ & $\begin{array}{l}-0.581 \\
(0.405)\end{array}$ & $\begin{array}{c}0.035^{* * *} \\
(0.010)\end{array}$ & $\begin{array}{c}1.394 * * * \\
(0.347)\end{array}$ & $\begin{array}{c}0.035^{* * *} \\
(0.012)\end{array}$ & $\begin{array}{c}1.072 * * * \\
(0.339)\end{array}$ & $\begin{array}{c}-0.125^{* * *} \\
(0.024)\end{array}$ & $\begin{array}{c}-2.807^{* * *} \\
(0.446)\end{array}$ & $\begin{array}{l}0.016 * * \\
(0.007)\end{array}$ \\
\hline Ever in school & $\begin{array}{c}0.060 * * * \\
(0.010)\end{array}$ & $\begin{array}{c}-2.010^{* *} \\
(0.745)\end{array}$ & $\begin{array}{c}0.003 \\
(0.009)\end{array}$ & $\begin{array}{c}-1.436 * * * \\
(0.384)\end{array}$ & $\begin{array}{c}0.001 \\
(0.008)\end{array}$ & $\begin{array}{c}-1.113^{* * *} \\
(0.365)\end{array}$ & $\begin{array}{c}0.067 * * * \\
(0.010)\end{array}$ & $\begin{array}{l}-0.606 * \\
(0.355)\end{array}$ & $\begin{array}{c}0.614^{* * *} \\
(0.018)\end{array}$ \\
\hline HhH male & $\begin{array}{l}0.010 * \\
(0.005)\end{array}$ & $\begin{array}{c}0.972 * * * \\
(0.246)\end{array}$ & $\begin{array}{l}0.014 * * \\
(0.006)\end{array}$ & $\begin{array}{c}0.431^{* * *} \\
(0.126)\end{array}$ & $\begin{array}{c}0.021^{* * *} \\
(0.007)\end{array}$ & $\begin{array}{c}0.394^{* * *} \\
(0.130)\end{array}$ & $\begin{array}{l}0.012 * \\
(0.006)\end{array}$ & $\begin{array}{l}0.323 * * \\
(0.158)\end{array}$ & $\begin{array}{l}-0.006 \\
(0.004)\end{array}$ \\
\hline $\begin{array}{l}\text { Mother lives at } \\
\text { home }\end{array}$ & $\begin{array}{c}-0.011^{* * *} \\
(0.004)\end{array}$ & $\begin{array}{l}-0.423 \\
(0.263)\end{array}$ & $\begin{array}{l}-0.000 \\
(0.006)\end{array}$ & $\begin{array}{l}-0.119 \\
(0.162)\end{array}$ & $\begin{array}{c}0.007 \\
(0.005)\end{array}$ & $\begin{array}{c}0.084 \\
(0.122)\end{array}$ & $\begin{array}{l}-0.005 \\
(0.004)\end{array}$ & $\begin{array}{c}-0.440 * * \\
(0.179)\end{array}$ & $\begin{array}{c}0.028 * * * \\
(0.006)\end{array}$ \\
\hline Father lives at home & $\begin{array}{l}-0.006 \\
(0.004)\end{array}$ & $\begin{array}{c}0.273 \\
(0.419)\end{array}$ & $\begin{array}{c}0.001 \\
(0.007)\end{array}$ & $\begin{array}{c}0.297 \\
(0.178)\end{array}$ & $\begin{array}{c}0.005 \\
(0.006)\end{array}$ & $\begin{array}{l}0.371 * * \\
(0.156)\end{array}$ & $\begin{array}{c}-0.009 * * \\
(0.004)\end{array}$ & $\begin{array}{l}-0.125 \\
(0.200)\end{array}$ & $\begin{array}{l}0.010 * * \\
(0.005)\end{array}$ \\
\hline $\begin{array}{l}\text { N. of siblings aged } \\
5-15\end{array}$ & $\begin{array}{l}-0.001 \\
(0.001)\end{array}$ & $\begin{array}{c}0.151 \\
(0.096)\end{array}$ & $\begin{array}{l}0.003 * \\
(0.002)\end{array}$ & $\begin{array}{c}0.095 \\
(0.066)\end{array}$ & $\begin{array}{l}0.003 * * \\
(0.002)\end{array}$ & $\begin{array}{c}0.069 \\
(0.056)\end{array}$ & $\begin{array}{l}-0.001 \\
(0.001)\end{array}$ & $\begin{array}{c}0.029 \\
(0.025)\end{array}$ & $\begin{array}{c}0.003 \\
(0.002)\end{array}$ \\
\hline $\begin{array}{l}\text { N. of children }<5 \\
\text { y.o. at home }\end{array}$ & $\begin{array}{l}0.004^{* *} \\
(0.001)\end{array}$ & $\begin{array}{l}0.200 * * \\
(0.094)\end{array}$ & $\begin{array}{l}0.002 * \\
(0.001)\end{array}$ & $\begin{array}{c}0.048 \\
(0.050)\end{array}$ & $\begin{array}{c}0.001 \\
(0.001)\end{array}$ & $\begin{array}{c}0.011 \\
(0.057)\end{array}$ & $\begin{array}{l}0.004^{* *} \\
(0.002)\end{array}$ & $\begin{array}{c}0.155^{* * *} \\
(0.048)\end{array}$ & $\begin{array}{c}-0.008^{* * *} \\
(0.003)\end{array}$ \\
\hline $\begin{array}{l}\text { N. of female adults } \\
\text { at home }\end{array}$ & $\begin{array}{c}-0.010 * * * \\
(0.002)\end{array}$ & $\begin{array}{c}-0.311^{* * *} \\
(0.101)\end{array}$ & $\begin{array}{l}-0.001 \\
(0.003)\end{array}$ & $\begin{array}{l}-0.081 \\
(0.070)\end{array}$ & $\begin{array}{l}-0.001 \\
(0.002)\end{array}$ & $\begin{array}{l}-0.100 * \\
(0.056)\end{array}$ & $\begin{array}{c}-0.008^{* * *} \\
(0.003)\end{array}$ & $\begin{array}{c}-0.246^{* * *} \\
(0.059)\end{array}$ & $\begin{array}{l}-0.000 \\
(0.001)\end{array}$ \\
\hline Household size & $\begin{array}{c}0.002 \\
(0.001)\end{array}$ & $\begin{array}{l}0.174 * \\
(0.091)\end{array}$ & $\begin{array}{c}0.002 \\
(0.002)\end{array}$ & $\begin{array}{c}0.085 \\
(0.056)\end{array}$ & $\begin{array}{c}0.002 \\
(0.002)\end{array}$ & $\begin{array}{l}0.099 * * \\
(0.043)\end{array}$ & $\begin{array}{c}0.000 \\
(0.001)\end{array}$ & $\begin{array}{c}0.043 \\
(0.035)\end{array}$ & $\begin{array}{c}0.000 \\
(0.001)\end{array}$ \\
\hline Birth order & $\begin{array}{l}-0.004 \\
(0.004)\end{array}$ & $\begin{array}{c}-0.681 * * * \\
(0.207)\end{array}$ & $\begin{array}{c}-0.008^{* * *} \\
(0.003)\end{array}$ & $\begin{array}{c}-0.294^{* *} \\
(0.111)\end{array}$ & $\begin{array}{c}-0.006^{* *} \\
(0.003)\end{array}$ & $\begin{array}{c}-0.212^{* *} \\
(0.091)\end{array}$ & $\begin{array}{c}-0.004 \\
(0.003)\end{array}$ & $\begin{array}{c}-0.318^{* * *} \\
(0.081)\end{array}$ & $\begin{array}{c}0.001 \\
(0.004)\end{array}$ \\
\hline Urban area & $\begin{array}{c}-0.052 * * * \\
(0.006)\end{array}$ & $\begin{array}{c}-5.359 * * * \\
(0.666)\end{array}$ & $\begin{array}{c}-0.123^{* * *} \\
(0.015)\end{array}$ & $\begin{array}{c}-2.593 * * * \\
(0.433)\end{array}$ & $\begin{array}{c}-0.132 * * * \\
(0.017)\end{array}$ & $\begin{array}{c}-2.514^{* * *} \\
(0.404)\end{array}$ & $\begin{array}{c}-0.032 * * * \\
(0.005)\end{array}$ & $\begin{array}{c}-1.146^{* * *} \\
(0.137)\end{array}$ & $\begin{array}{c}0.032 * * * \\
(0.007)\end{array}$ \\
\hline \multicolumn{10}{|l|}{ Wealth index: } \\
\hline 1st quantile & $\begin{array}{c}0.074^{* * *} \\
(0.011)\end{array}$ & $\begin{array}{c}5.989 * * * \\
(0.616)\end{array}$ & $\begin{array}{c}0.129 * * * \\
(0.016)\end{array}$ & $\begin{array}{c}3.174^{* * *} \\
(0.464)\end{array}$ & $\begin{array}{c}0.134^{* * *} \\
(0.018)\end{array}$ & $\begin{array}{c}2.621^{* * *} \\
(0.384)\end{array}$ & $\begin{array}{c}0.046^{* * *} \\
(0.010)\end{array}$ & $\begin{array}{c}1.372^{* * *} \\
(0.290)\end{array}$ & $\begin{array}{c}-0.103^{* * *} \\
(0.013)\end{array}$ \\
\hline 2nd quantile & $\begin{array}{c}0.053^{* * *} \\
(0.009)\end{array}$ & $\begin{array}{c}4.597 * * * \\
(0.780)\end{array}$ & $\begin{array}{c}0.099 * * * \\
(0.018)\end{array}$ & $\begin{array}{c}2.434^{* * *} \\
(0.510)\end{array}$ & $\begin{array}{c}0.104^{* * *} \\
(0.019)\end{array}$ & $\begin{array}{c}1.904^{* * *} \\
(0.438)\end{array}$ & $\begin{array}{c}0.038 * * * \\
(0.011)\end{array}$ & $\begin{array}{c}0.944 * * * \\
(0.266)\end{array}$ & $\begin{array}{c}-0.077 * * * \\
(0.014)\end{array}$ \\
\hline 3rd quantile & $\begin{array}{c}0.045^{* * * *} \\
(0.009)\end{array}$ & $\begin{array}{c}3.712 * * * \\
(0.831)\end{array}$ & $\begin{array}{c}0.086 * * * \\
(0.019)\end{array}$ & $\begin{array}{c}1.866 * * * \\
(0.476)\end{array}$ & $\begin{array}{c}0.085 * * * \\
(0.020)\end{array}$ & $\begin{array}{c}1.376^{* * *} \\
(0.414)\end{array}$ & $\begin{array}{c}0.032 * * * \\
(0.009)\end{array}$ & $\begin{array}{c}0.802 * * * \\
(0.242)\end{array}$ & $\begin{array}{c}-0.050 * * * \\
(0.009)\end{array}$ \\
\hline 4th quantile & $\begin{array}{c}0.022^{* * *} \\
(0.008)\end{array}$ & $\begin{array}{c}2.263^{* * *} \\
(0.716)\end{array}$ & $\begin{array}{c}0.047^{* * *} \\
(0.014)\end{array}$ & $\begin{array}{l}1.129 * * \\
(0.417)\end{array}$ & $\begin{array}{c}0.050 * * * \\
(0.015)\end{array}$ & $\begin{array}{c}0.827 * * \\
(0.372)\end{array}$ & $\begin{array}{c}0.018 * * \\
(0.007)\end{array}$ & $\begin{array}{c}0.519 * * \\
(0.250)\end{array}$ & $\begin{array}{c}-0.032 * * * \\
(0.006)\end{array}$ \\
\hline Constant & $\begin{array}{c}0.292 * * * \\
(0.046)\end{array}$ & $\begin{array}{c}-7.700 * * * \\
(1.714)\end{array}$ & $\begin{array}{c}-0.071^{* * *} \\
(0.023)\end{array}$ & $\begin{array}{c}-5.474^{* * *} \\
(1.123)\end{array}$ & $\begin{array}{c}-0.124^{* * *} \\
(0.026)\end{array}$ & $\begin{array}{c}-4.293 * * * \\
(0.879)\end{array}$ & $\begin{array}{c}0.328 * * * \\
(0.046)\end{array}$ & $\begin{array}{c}0.056 \\
(0.838)\end{array}$ & $\begin{array}{c}-0.176^{* * *} \\
(0.031)\end{array}$ \\
\hline Observations & 247,975 & 246,738 & 249,594 & 249,348 & 247,992 & 247,974 & 248,451 & 248,214 & 168,841 \\
\hline R-squared & 0.258 & 0.244 & 0.239 & 0.132 & 0.216 & 0.113 & 0.241 & 0.177 & 0.219 \\
\hline
\end{tabular}

Robust standard errors are reported in parentheses, clustered at the country level. ${ }^{* * *} \mathrm{p}<0.01,{ }^{* *} \mathrm{p}<0.05$, * $\mathrm{p}<0.1$

Notes: Dependent variables are dichotomous indicators as well as continuous variables (i.e. hours) for work supply in the last week. School attendance is a dichotomous variable referred to the last year. The sample includes children aged 5-14 in 38 countries. The table reports linear probability model results. Reference categories for reported dummy variables are 'higher education (i.e. more than primary)', 'female', 'female household's head', 'rural area'. Other controls include dummies for missing information on household head's education, wealth index, rural/urban area and country fixed effects. 
Table 4 - Migration outflows and child labor (largest sample)

\begin{tabular}{|c|c|c|c|c|c|c|c|c|c|}
\hline & Any work & $\begin{array}{c}(2) \\
\text { Total hours } \\
\text { of work }\end{array}$ & $\begin{array}{c}\text { (3) } \\
\text { Market } \\
\text { work }\end{array}$ & $\begin{array}{c}\text { (4) } \\
\text { Hours in } \\
\text { market } \\
\text { work }\end{array}$ & $\begin{array}{c}\text { (5) } \\
\text { Family } \\
\text { business }\end{array}$ & $\begin{array}{c}(6) \\
\text { Hours in } \\
\text { family } \\
\text { business }\end{array}$ & Chores & $\begin{array}{c}\text { (8) } \\
\text { Hours in } \\
\text { chores }\end{array}$ & $\begin{array}{c}\text { (9) } \\
\text { School } \\
\text { attendance }\end{array}$ \\
\hline Mig. I & $-0.120 * *$ & -7.2 & -0.0 & -2.987 & -0 . & -2.179 & -0.11 & -3.0 & 0.0 \\
\hline low-skill & $(0.051)$ & $(3.874)$ & $(0.074)$ & $(2.463)$ & $(0.085)$ & (1.949) & $(0.047)$ & (1.239) & $(0.041)$ \\
\hline HhH low-skilled & $\begin{array}{c}0.021^{* * *} \\
(0.006)\end{array}$ & $\begin{array}{l}1.029 * \\
(0.518)\end{array}$ & $\begin{array}{l}0.018 * * \\
(0.009)\end{array}$ & $\begin{array}{c}0.411 \\
(0.359)\end{array}$ & $\begin{array}{l}0.021 * * \\
(0.010)\end{array}$ & $\begin{array}{c}0.184 \\
(0.290)\end{array}$ & $\begin{array}{c}0.022^{* * *} \\
(0.005)\end{array}$ & $\begin{array}{c}0.487 * * * \\
(0.159)\end{array}$ & $\begin{array}{c}-0.031^{* * *} \\
(0.007)\end{array}$ \\
\hline Age & $\begin{array}{c}0.045^{* * *} \\
(0.005)\end{array}$ & $\begin{array}{c}2.433 * * * \\
(0.195)\end{array}$ & $\begin{array}{c}0.033^{* * * *} \\
(0.002)\end{array}$ & $\begin{array}{c}1.020 * * * \\
(0.104)\end{array}$ & $\begin{array}{c}0.030 * * * \\
(0.002)\end{array}$ & $\begin{array}{c}0.764 * * * \\
(0.087)\end{array}$ & $\begin{array}{c}0.040 * * * \\
(0.005)\end{array}$ & $\begin{array}{c}1.067 * * * \\
(0.106)\end{array}$ & $\begin{array}{c}0.040^{* * *} \\
(0.003)\end{array}$ \\
\hline Male & $\begin{array}{c}-0.078 * * * \\
(0.017)\end{array}$ & $\begin{array}{l}-0.581 \\
(0.405)\end{array}$ & $\begin{array}{c}0.035^{* * *} \\
(0.010)\end{array}$ & $\begin{array}{c}1.394 * * * \\
(0.347)\end{array}$ & $\begin{array}{c}0.035^{* * *} \\
(0.012)\end{array}$ & $\begin{array}{c}1.072 * * * \\
(0.339)\end{array}$ & $\begin{array}{c}-0.125^{* * *} \\
(0.024)\end{array}$ & $\begin{array}{c}-2.807^{* * *} \\
(0.446)\end{array}$ & $\begin{array}{l}0.016 * * \\
(0.007)\end{array}$ \\
\hline Ever in school & $\begin{array}{c}0.060 * * * \\
(0.010)\end{array}$ & $\begin{array}{c}-2.005^{* *} \\
(0.747)\end{array}$ & $\begin{array}{c}0.003 \\
(0.009)\end{array}$ & $\begin{array}{c}-1.434^{* * *} \\
(0.385)\end{array}$ & $\begin{array}{c}0.001 \\
(0.008)\end{array}$ & $\begin{array}{c}-1.112^{* * *} \\
(0.365)\end{array}$ & $\begin{array}{c}0.067 * * * \\
(0.010)\end{array}$ & $\begin{array}{l}-0.605^{*} \\
(0.355)\end{array}$ & $\begin{array}{c}0.614^{* * *} \\
(0.018)\end{array}$ \\
\hline HhH male & $\begin{array}{l}0.010^{*} \\
(0.005)\end{array}$ & $\begin{array}{c}0.981 * * * \\
(0.245)\end{array}$ & $\begin{array}{l}0.014 * * \\
(0.006)\end{array}$ & $\begin{array}{c}0.434 * * * \\
(0.125)\end{array}$ & $\begin{array}{c}0.021^{* * *} \\
(0.007)\end{array}$ & $\begin{array}{c}0.397 * * * \\
(0.129)\end{array}$ & $\begin{array}{l}0.012^{*} \\
(0.006)\end{array}$ & $\begin{array}{l}0.327 * * \\
(0.157)\end{array}$ & $\begin{array}{l}-0.006 \\
(0.004)\end{array}$ \\
\hline $\begin{array}{l}\text { Mother lives at } \\
\text { home }\end{array}$ & $\begin{array}{c}-0.011 * * * \\
(0.004)\end{array}$ & $\begin{array}{l}-0.425 \\
(0.263)\end{array}$ & $\begin{array}{l}-0.000 \\
(0.006)\end{array}$ & $\begin{array}{l}-0.120 \\
(0.162)\end{array}$ & $\begin{array}{c}0.007 \\
(0.005)\end{array}$ & $\begin{array}{c}0.084 \\
(0.122)\end{array}$ & $\begin{array}{l}-0.005 \\
(0.004)\end{array}$ & $\begin{array}{c}-0.441^{* *} \\
(0.179)\end{array}$ & $\begin{array}{c}0.028 * * * \\
(0.006)\end{array}$ \\
\hline $\begin{array}{l}\text { Father lives at } \\
\text { home }\end{array}$ & $\begin{array}{l}-0.006 \\
(0.004)\end{array}$ & $\begin{array}{c}0.271 \\
(0.420)\end{array}$ & $\begin{array}{c}0.001 \\
(0.007)\end{array}$ & $\begin{array}{c}0.296 \\
(0.178)\end{array}$ & $\begin{array}{c}0.005 \\
(0.006)\end{array}$ & $\begin{array}{l}0.371 * * \\
(0.156)\end{array}$ & $\begin{array}{c}-0.009 * * \\
(0.004)\end{array}$ & $\begin{array}{l}-0.126 \\
(0.200)\end{array}$ & $\begin{array}{l}0.010 * * \\
(0.005)\end{array}$ \\
\hline $\begin{array}{l}\text { N. of siblings aged } \\
5-15\end{array}$ & $\begin{array}{l}-0.001 \\
(0.001)\end{array}$ & $\begin{array}{c}0.151 \\
(0.095)\end{array}$ & $\begin{array}{l}0.003 * \\
(0.002)\end{array}$ & $\begin{array}{c}0.096 \\
(0.066)\end{array}$ & $\begin{array}{l}0.003 * * \\
(0.002)\end{array}$ & $\begin{array}{c}0.069 \\
(0.056)\end{array}$ & $\begin{array}{l}-0.001 \\
(0.001)\end{array}$ & $\begin{array}{c}0.029 \\
(0.025)\end{array}$ & $\begin{array}{c}0.003 \\
(0.002)\end{array}$ \\
\hline $\begin{array}{l}\text { N. of children }<5 \\
\text { y.o. at home }\end{array}$ & $\begin{array}{l}0.004^{* *} \\
(0.001)\end{array}$ & $\begin{array}{l}0.199 * * \\
(0.094)\end{array}$ & $\begin{array}{l}0.002 * \\
(0.001)\end{array}$ & $\begin{array}{c}0.047 \\
(0.050)\end{array}$ & $\begin{array}{c}0.001 \\
(0.001)\end{array}$ & $\begin{array}{c}0.010 \\
(0.057)\end{array}$ & $\begin{array}{l}0.004^{* *} \\
(0.002)\end{array}$ & $\begin{array}{c}0.154^{* * *} \\
(0.048)\end{array}$ & $\begin{array}{c}-0.008 * * * \\
(0.003)\end{array}$ \\
\hline $\begin{array}{l}\text { N. of female } \\
\text { adults at home }\end{array}$ & $\begin{array}{c}-0.010^{* * *} \\
(0.002)\end{array}$ & $\begin{array}{c}-0.311^{* * *} \\
(0.100)\end{array}$ & $\begin{array}{l}-0.001 \\
(0.003)\end{array}$ & $\begin{array}{l}-0.081 \\
(0.070)\end{array}$ & $\begin{array}{l}-0.001 \\
(0.002)\end{array}$ & $\begin{array}{l}-0.100 * \\
(0.056)\end{array}$ & $\begin{array}{c}-0.008 * * * \\
(0.003)\end{array}$ & $\begin{array}{c}-0.246^{* * *} \\
(0.059)\end{array}$ & $\begin{array}{l}-0.000 \\
(0.001)\end{array}$ \\
\hline Household size & $\begin{array}{c}0.002 \\
(0.001)\end{array}$ & $\begin{array}{l}0.175^{*} \\
(0.091)\end{array}$ & $\begin{array}{c}0.002 \\
(0.002)\end{array}$ & $\begin{array}{c}0.085 \\
(0.056)\end{array}$ & $\begin{array}{c}0.002 \\
(0.002)\end{array}$ & $\begin{array}{l}0.099 * * \\
(0.043)\end{array}$ & $\begin{array}{c}0.000 \\
(0.001)\end{array}$ & $\begin{array}{c}0.043 \\
(0.035)\end{array}$ & $\begin{array}{c}0.000 \\
(0.001)\end{array}$ \\
\hline Birth order & $\begin{array}{l}-0.004 \\
(0.004)\end{array}$ & $\begin{array}{c}-0.681^{* * *} \\
(0.207)\end{array}$ & $\begin{array}{c}-0.008 * * * \\
(0.003)\end{array}$ & $\begin{array}{l}-0.294 * * \\
(0.111)\end{array}$ & $\begin{array}{c}-0.006^{* *} \\
(0.003)\end{array}$ & $\begin{array}{c}-0.212^{* *} \\
(0.091)\end{array}$ & $\begin{array}{c}-0.004 \\
(0.003)\end{array}$ & $\begin{array}{c}-0.319 * * * \\
(0.081)\end{array}$ & $\begin{array}{c}0.001 \\
(0.004)\end{array}$ \\
\hline Urban area & $\begin{array}{c}-0.052^{* * *} \\
(0.006)\end{array}$ & $\begin{array}{c}-5.357 * * * \\
(0.665)\end{array}$ & $\begin{array}{c}-0.123^{* * *} \\
(0.015)\end{array}$ & $\begin{array}{c}-2.592^{* * *} \\
(0.433)\end{array}$ & $\begin{array}{c}-0.132^{* * *} \\
(0.017)\end{array}$ & $\begin{array}{c}-2.513^{* * *} \\
(0.404)\end{array}$ & $\begin{array}{c}-0.032 * * * \\
(0.005)\end{array}$ & $\begin{array}{c}-1.145^{* * *} \\
(0.137)\end{array}$ & $\begin{array}{c}0.032 * * * \\
(0.007)\end{array}$ \\
\hline \multicolumn{10}{|l|}{ Wealth index } \\
\hline 1st quantile & $\begin{array}{c}0.074 * * * \\
(0.011)\end{array}$ & $\begin{array}{c}5.987 * * * \\
(0.617)\end{array}$ & $\begin{array}{c}0.129 * * * \\
(0.016)\end{array}$ & $\begin{array}{c}3.173^{* * *} \\
(0.464)\end{array}$ & $\begin{array}{c}0.134^{* * *} \\
(0.018)\end{array}$ & $\begin{array}{c}2.621 * * * \\
(0.384)\end{array}$ & $\begin{array}{c}0.046 * * * \\
(0.010)\end{array}$ & $\begin{array}{c}1.371^{* * * *} \\
(0.290)\end{array}$ & $\begin{array}{c}-0.103^{* * * *} \\
(0.013)\end{array}$ \\
\hline 2nd quantile & $\begin{array}{c}0.053^{* * *} \\
(0.009)\end{array}$ & $\begin{array}{c}4.589 * * * \\
(0.780)\end{array}$ & $\begin{array}{c}0.099 * * * \\
(0.018)\end{array}$ & $\begin{array}{c}2.431^{* * *} \\
(0.509)\end{array}$ & $\begin{array}{c}0.104^{* * *} \\
(0.019)\end{array}$ & $\begin{array}{c}1.902 * * * \\
(0.437)\end{array}$ & $\begin{array}{c}0.038 * * * \\
(0.011)\end{array}$ & $\begin{array}{c}0.941^{* * *} \\
(0.266)\end{array}$ & $\begin{array}{c}-0.077^{* * * *} \\
(0.014)\end{array}$ \\
\hline 3rd quantile & $\begin{array}{c}0.045^{* * *} \\
(0.009)\end{array}$ & $\begin{array}{c}3.702 * * * \\
(0.830)\end{array}$ & $\begin{array}{c}0.086 * * * \\
(0.019)\end{array}$ & $\begin{array}{c}1.862 * * * \\
(0.474)\end{array}$ & $\begin{array}{c}0.085^{* * * *} \\
(0.020)\end{array}$ & $\begin{array}{c}1.373 * * * \\
(0.412)\end{array}$ & $\begin{array}{c}0.032 * * * \\
(0.009)\end{array}$ & $\begin{array}{c}0.798 * * * \\
(0.242)\end{array}$ & $\begin{array}{c}-0.050 * * * \\
(0.009)\end{array}$ \\
\hline 4th quantile & $\begin{array}{c}0.022 * * * \\
(0.008)\end{array}$ & $\begin{array}{c}2.252^{* * *} \\
(0.716)\end{array}$ & $\begin{array}{c}0.047 * * * \\
(0.014)\end{array}$ & $\begin{array}{l}1.125 * * \\
(0.416)\end{array}$ & $\begin{array}{c}0.050 * * * \\
(0.015)\end{array}$ & $\begin{array}{c}0.824 * * \\
(0.371)\end{array}$ & $\begin{array}{c}0.017 * * \\
(0.007)\end{array}$ & $\begin{array}{c}0.515 * * \\
(0.250)\end{array}$ & $\begin{array}{c}-0.032 * * * \\
(0.006)\end{array}$ \\
\hline Constant & $\begin{array}{c}0.292 * * * \\
(0.046)\end{array}$ & $\begin{array}{c}-7.724^{* * *} \\
(1.717)\end{array}$ & $\begin{array}{c}-0.071^{* * *} \\
(0.023)\end{array}$ & $\begin{array}{c}-5.484^{* * *} \\
(1.125)\end{array}$ & $\begin{array}{c}-0.125^{* * *} \\
(0.027)\end{array}$ & $\begin{array}{c}-4.300 * * * \\
(0.881)\end{array}$ & $\begin{array}{c}0.327 * * * \\
(0.046)\end{array}$ & $\begin{array}{c}0.045 \\
(0.839)\end{array}$ & $\begin{array}{c}-0.176^{* * *} \\
(0.031)\end{array}$ \\
\hline Observations & 247,975 & 246,738 & 249,594 & 249,348 & 247,992 & 247,974 & 248,451 & 248,214 & 168,841 \\
\hline R-squared & 0.258 & 0.244 & 0.239 & 0.132 & 0.216 & 0.113 & 0.241 & 0.177 & 0.219 \\
\hline
\end{tabular}

Robust standard errors are reported in parentheses, clustered at the country level. ${ }^{* * *} \mathrm{p}<0.01,{ }^{* *} \mathrm{p}<0.05$, * $\mathrm{p}<0.1$

Notes: Dependent variables are dichotomous indicators as well as continuous variables (i.e. hours) for work supply in the last week. School attendance is a dichotomous variable referred to the last year. The sample includes children aged 5-14 in 38 countries. The table reports linear probability model results. Reference categories for reported dummy variables are 'higher education (i.e. more than primary)', 'female', 'female household's head', 'rural area'. Other controls include dummies for missing information on household head's education, wealth index, rural/urban area and country fixed effects. 
Table 5 - Migration outflows and child labor (smallest sample)

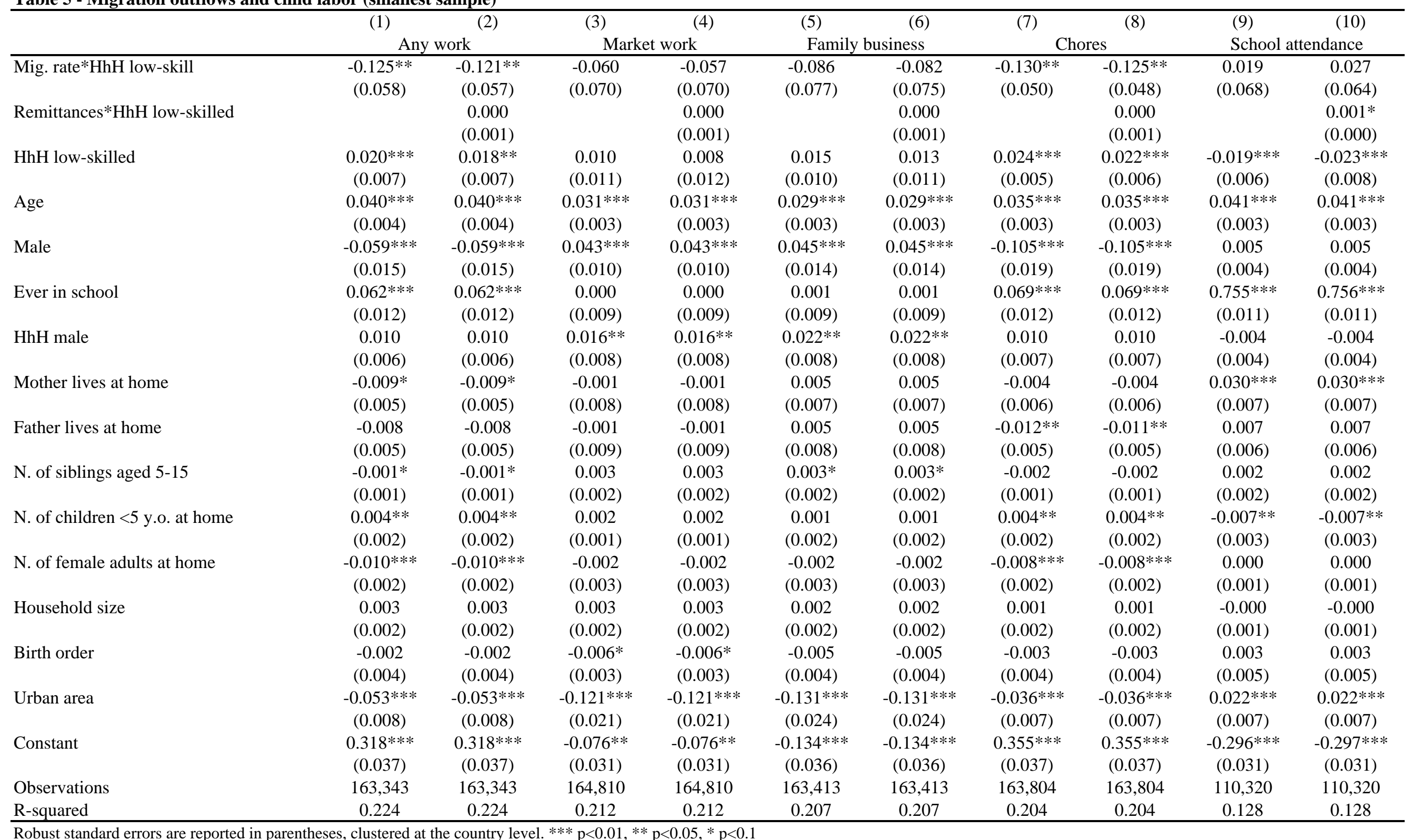

Robust standard errors are reported in parentheses, clustered at the country level. ${ }^{* *} \mathrm{p}<0.01,{ }^{* *} \mathrm{p}<0.05,{ }^{*} \mathrm{p}<0.1$

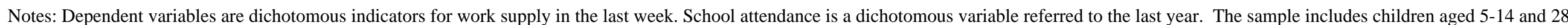

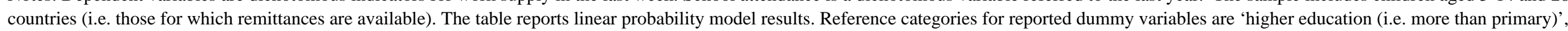
'female', 'female household's head', 'rural area'. Other controls include dummies for missing information on household head's education, wealth index, rural/urban area and country fixed effects. 
Table 6 - Skill composition of migration outflows and child labor (largest sample)

$$
\text { (1) }
$$

(2)

Any work

(2)
Total hours Market of work work
(4)

Hours in

market work
(6)

Hours in
(5)

Family
business family business business

\begin{abstract}
(7)
\end{abstract}
(8)

(9)
Chores Hours in School chores attendance

\begin{tabular}{|c|c|c|c|c|c|c|c|c|c|}
\hline $\begin{array}{l}\text { Mig. low- } \\
\text { skill*HhH low- }\end{array}$ & $\begin{array}{c}-0.166 * * \\
(0.064)\end{array}$ & $\begin{array}{c}-10.092 * \\
(5.051)\end{array}$ & $\begin{array}{l}-0.128 \\
(0.098)\end{array}$ & $\begin{array}{l}-3.793 \\
(3.229)\end{array}$ & $\begin{array}{l}-0.149 \\
(0.112)\end{array}$ & $\begin{array}{l}-2.899 \\
(2.592)\end{array}$ & $\begin{array}{c}-0.159 * * \\
(0.061)\end{array}$ & $\begin{array}{c}-4.303^{* *} \\
(1.714)\end{array}$ & $\begin{array}{c}0.091 \\
(0.059)\end{array}$ \\
\hline HhH low-skilled & $\begin{array}{c}0.020 * * * \\
(0.006)\end{array}$ & $\begin{array}{l}1.013^{*} \\
(0.507)\end{array}$ & $\begin{array}{l}0.018 * * \\
(0.009)\end{array}$ & $\begin{array}{c}0.398 \\
(0.353)\end{array}$ & $\begin{array}{l}0.020 * * \\
(0.009)\end{array}$ & $\begin{array}{c}0.177 \\
(0.286)\end{array}$ & $\begin{array}{c}0.021 * * * \\
(0.004)\end{array}$ & $\begin{array}{c}0.482^{* * *} \\
(0.156)\end{array}$ & $\begin{array}{c}-0.031^{* * *} \\
(0.007)\end{array}$ \\
\hline Age & $\begin{array}{c}0.045 * * * \\
(0.005)\end{array}$ & $\begin{array}{c}2.433^{* * *} \\
(0.195)\end{array}$ & $\begin{array}{c}0.033^{* * *} \\
(0.002)\end{array}$ & $\begin{array}{c}1.020 * * * \\
(0.104)\end{array}$ & $\begin{array}{c}0.030 * * * \\
(0.002)\end{array}$ & $\begin{array}{c}0.764 * * * \\
(0.087)\end{array}$ & $\begin{array}{c}0.040 * * * \\
(0.005)\end{array}$ & $\begin{array}{c}1.067^{* * *} \\
(0.106)\end{array}$ & $\begin{array}{c}0.040 * * * \\
(0.003)\end{array}$ \\
\hline Male & $\begin{array}{c}-0.078 * * * \\
(0.017)\end{array}$ & $\begin{array}{l}-0.581 \\
(0.405)\end{array}$ & $\begin{array}{c}0.035 * * * \\
(0.010)\end{array}$ & $\begin{array}{c}1.394 * * * \\
(0.347)\end{array}$ & $\begin{array}{c}0.035^{* * *} \\
(0.012)\end{array}$ & $\begin{array}{c}1.072 * * * \\
(0.339)\end{array}$ & $\begin{array}{c}-0.125^{* * *} \\
(0.024)\end{array}$ & $\begin{array}{c}-2.806 * * * \\
(0.446)\end{array}$ & $\begin{array}{l}0.016 * * \\
(0.007)\end{array}$ \\
\hline Ever in school & $\begin{array}{c}0.060 * * * \\
(0.010)\end{array}$ & $\begin{array}{c}-2.005 * * \\
(0.747)\end{array}$ & $\begin{array}{c}0.003 \\
(0.009)\end{array}$ & $\begin{array}{c}-1.434 * * * \\
(0.385)\end{array}$ & $\begin{array}{c}0.001 \\
(0.008)\end{array}$ & $\begin{array}{c}-1.112 * * * \\
(0.365)\end{array}$ & $\begin{array}{c}0.067 * * * \\
(0.010)\end{array}$ & $\begin{array}{l}-0.605^{*} \\
(0.355)\end{array}$ & $\begin{array}{c}0.614^{* * *} \\
(0.018)\end{array}$ \\
\hline HhH male & $\begin{array}{l}0.010^{*} \\
(0.005)\end{array}$ & $\begin{array}{c}0.982 * * * \\
(0.245)\end{array}$ & $\begin{array}{l}0.014 * * \\
(0.006)\end{array}$ & $\begin{array}{c}0.434^{* * *} \\
(0.125)\end{array}$ & $\begin{array}{c}0.021^{* * *} \\
(0.007)\end{array}$ & $\begin{array}{c}0.397 * * * \\
(0.129)\end{array}$ & $\begin{array}{l}0.012 * \\
(0.006)\end{array}$ & $\begin{array}{l}0.327 * * \\
(0.158)\end{array}$ & $\begin{array}{l}-0.006 \\
(0.004)\end{array}$ \\
\hline $\begin{array}{l}\text { Mother lives at } \\
\text { home }\end{array}$ & $\begin{array}{c}-0.011 * * * \\
(0.004)\end{array}$ & $\begin{array}{l}-0.425 \\
(0.263)\end{array}$ & $\begin{array}{l}-0.000 \\
(0.006)\end{array}$ & $\begin{array}{l}-0.120 \\
(0.162)\end{array}$ & $\begin{array}{c}0.007 \\
(0.005)\end{array}$ & $\begin{array}{c}0.084 \\
(0.122)\end{array}$ & $\begin{array}{l}-0 . \\
(0 .\end{array}$ & $\begin{array}{c}-0.441^{* *} \\
(0.179)\end{array}$ & $\begin{array}{c}0.028 * * * \\
(0.006)\end{array}$ \\
\hline $\begin{array}{l}\text { Father lives at } \\
\text { home }\end{array}$ & $\begin{array}{l}-0.006 \\
(0.004)\end{array}$ & $\begin{array}{c}0.271 \\
(0.420)\end{array}$ & $\begin{array}{c}0.001 \\
(0.007)\end{array}$ & $\begin{array}{c}0.296 \\
(0.178)\end{array}$ & $\begin{array}{c}0.005 \\
(0.006)\end{array}$ & $\begin{array}{c}0.371^{* *} \\
(0.156)\end{array}$ & $\begin{array}{c}-0.009 * * \\
(0.004)\end{array}$ & $\begin{array}{l}-0.126 \\
(0.200)\end{array}$ & $\begin{array}{c}0.010 * * \\
(0.005)\end{array}$ \\
\hline $\begin{array}{l}\text { N. of siblings } \\
\text { aged 5-15 }\end{array}$ & $\begin{array}{l}-0.001 \\
(0.001)\end{array}$ & $\begin{array}{c}0.151 \\
(0.095)\end{array}$ & $\begin{array}{l}0.003^{*} \\
(0.002)\end{array}$ & $\begin{array}{c}0.096 \\
(0.066)\end{array}$ & $\begin{array}{l}0.003 * * \\
(0.002)\end{array}$ & $\begin{array}{c}0.069 \\
(0.056)\end{array}$ & $\begin{array}{l}-0 . \\
(0.0\end{array}$ & $\begin{array}{c}0.029 \\
(0.025)\end{array}$ & $\begin{array}{c}0.003 \\
(0.002)\end{array}$ \\
\hline $\begin{array}{l}\text { N. of children }<5 \\
\text { y.o. at home }\end{array}$ & $\begin{array}{l}0.004 * * \\
(0.001)\end{array}$ & $\begin{array}{l}0.199 * * \\
(0.094)\end{array}$ & $\begin{array}{l}0.002 * \\
(0.001)\end{array}$ & $\begin{array}{c}0.047 \\
(0.050)\end{array}$ & $\begin{array}{c}0.001 \\
(0.001)\end{array}$ & $\begin{array}{c}0.010 \\
(0.057)\end{array}$ & $\begin{array}{l}0.0 \\
(0 .\end{array}$ & $\begin{array}{c}0.154^{* * *} \\
(0.048)\end{array}$ & $\begin{array}{c}-0.008 * * * \\
(0.003)\end{array}$ \\
\hline $\begin{array}{l}\text { N. of female } \\
\text { adults at home }\end{array}$ & $\begin{array}{c}-0.010 * * * \\
(0.002)\end{array}$ & $\begin{array}{c}-0.311^{* * * *} \\
(0.100)\end{array}$ & $\begin{array}{l}-0.001 \\
(0.003)\end{array}$ & $\begin{array}{l}-0.081 \\
(0.070)\end{array}$ & $\begin{array}{l}-0.001 \\
(0.002)\end{array}$ & $\begin{array}{l}-0.100 * \\
(0.055)\end{array}$ & $\begin{array}{c}-0.008 * * * \\
(0.003)\end{array}$ & $\begin{array}{c}-0.246 * * * \\
(0.059)\end{array}$ & $\begin{array}{l}-0.000 \\
(0.001)\end{array}$ \\
\hline Household size & $\begin{array}{c}0.002 \\
(0.001)\end{array}$ & $\begin{array}{l}0.175^{*} \\
(0.091)\end{array}$ & $\begin{array}{c}0.002 \\
(0.002)\end{array}$ & $\begin{array}{c}0.085 \\
(0.056)\end{array}$ & $\begin{array}{c}0.002 \\
(0.002)\end{array}$ & $\begin{array}{l}0.099 * * \\
(0.043)\end{array}$ & $\begin{array}{c}0.000 \\
(0.001)\end{array}$ & $\begin{array}{c}0.043 \\
(0.035)\end{array}$ & $\begin{array}{c}0.000 \\
(0.001)\end{array}$ \\
\hline Birth order & $\begin{array}{l}-0.004 \\
(0.004)\end{array}$ & $\begin{array}{c}-0.681 * * * \\
(0.207)\end{array}$ & $\begin{array}{c}-0.008 * * * \\
(0.003)\end{array}$ & $\begin{array}{c}-0.294 * * \\
(0.111)\end{array}$ & $\begin{array}{c}-0.006^{* *} \\
(0.003)\end{array}$ & $\begin{array}{c}-0.212^{* *} \\
(0.091)\end{array}$ & $\begin{array}{l}-0.004 \\
(0.003)\end{array}$ & $\begin{array}{c}-0.319 * * * \\
(0.081)\end{array}$ & $\begin{array}{c}0.001 \\
(0.004)\end{array}$ \\
\hline Urban area & $\begin{array}{c}-0.052^{* * *} \\
(0.006)\end{array}$ & $\begin{array}{c}-5.357 * * * \\
(0.665)\end{array}$ & $\begin{array}{c}-0.123^{* * *} \\
(0.015)\end{array}$ & $\begin{array}{c}-2.592^{* * *} \\
(0.433)\end{array}$ & $\begin{array}{c}-0.132 * * * \\
(0.017)\end{array}$ & $\begin{array}{c}-2.513^{* * *} \\
(0.404)\end{array}$ & $\begin{array}{c}-0.032^{* * *} \\
(0.005)\end{array}$ & $\begin{array}{c}-1.145^{* * *} \\
(0.137)\end{array}$ & $\begin{array}{c}0.032 * * * \\
(0.007)\end{array}$ \\
\hline \multicolumn{10}{|l|}{ Wealth index } \\
\hline 1st quantile & $\begin{array}{c}0.074^{* * *} \\
(0.011)\end{array}$ & $\begin{array}{c}5.986 * * * \\
(0.617)\end{array}$ & $\begin{array}{c}0.129 * * * \\
(0.016)\end{array}$ & $\begin{array}{c}3.173 * * * \\
(0.464)\end{array}$ & $\begin{array}{c}0.134^{* * *} \\
(0.018)\end{array}$ & $\begin{array}{c}2.620 * * * \\
(0.384)\end{array}$ & $\begin{array}{c}0.046^{* * *} \\
(0.010)\end{array}$ & $\begin{array}{c}1.371^{* * *} \\
(0.290)\end{array}$ & $\begin{array}{c}-0.103^{* * * *} \\
(0.013)\end{array}$ \\
\hline 2nd quantile & $\begin{array}{c}0.053^{* * *} \\
(0.009)\end{array}$ & $\begin{array}{c}4.588 * * * \\
(0.780)\end{array}$ & $\begin{array}{c}0.099 * * * \\
(0.018)\end{array}$ & $\begin{array}{c}2.430 * * * \\
(0.509)\end{array}$ & $\begin{array}{c}0.104^{* * *} \\
(0.019)\end{array}$ & $\begin{array}{c}1.902 * * * \\
(0.437)\end{array}$ & $\begin{array}{c}0.038 * * * \\
(0.011)\end{array}$ & $\begin{array}{c}0.941^{* * *} \\
(0.266)\end{array}$ & $\begin{array}{c}-0.077^{* * *} \\
(0.014)\end{array}$ \\
\hline 3rd quantile & $\begin{array}{c}0.045^{* * *} \\
(0.009)\end{array}$ & $\begin{array}{c}3.702 * * * \\
(0.830)\end{array}$ & $\begin{array}{c}0.086 * * * \\
(0.019)\end{array}$ & $\begin{array}{c}1.862^{* * *} \\
(0.475)\end{array}$ & $\begin{array}{c}0.085^{* * * *} \\
(0.020)\end{array}$ & $\begin{array}{c}1.373^{* * *} \\
(0.412)\end{array}$ & $\begin{array}{c}0.032 * * * \\
(0.009)\end{array}$ & $\begin{array}{c}0.797 * * * \\
(0.242)\end{array}$ & $\begin{array}{c}-0.050 * * * \\
(0.009)\end{array}$ \\
\hline 4th quantile & $\begin{array}{c}0.022^{* * *} \\
(0.008)\end{array}$ & $\begin{array}{c}2.252 * * * \\
(0.716)\end{array}$ & $\begin{array}{c}0.047 * * * \\
(0.014)\end{array}$ & $\begin{array}{l}1.125 * * \\
(0.416)\end{array}$ & $\begin{array}{c}0.050 * * * \\
(0.015)\end{array}$ & $\begin{array}{l}0.824^{* *} \\
(0.371)\end{array}$ & $\begin{array}{l}0.017 * * \\
(0.007)\end{array}$ & $\begin{array}{l}0.515^{* *} \\
(0.250)\end{array}$ & $\begin{array}{c}-0.032^{* * *} \\
(0.006)\end{array}$ \\
\hline Constant & $\begin{array}{c}0.292 * * * \\
(0.046)\end{array}$ & $\begin{array}{c}-7.722^{* * *} \\
(1.717)\end{array}$ & $\begin{array}{c}-0.071 * * * \\
(0.023)\end{array}$ & $\begin{array}{c}-5.483^{* * *} \\
(1.125)\end{array}$ & $\begin{array}{c}-0.125^{* * *} \\
(0.027)\end{array}$ & $\begin{array}{c}-4.300^{* * *} \\
(0.881)\end{array}$ & $\begin{array}{c}0.327 * * * \\
(0.046)\end{array}$ & $\begin{array}{c}0.046 \\
(0.840)\end{array}$ & $\begin{array}{c}-0.176^{* * *} \\
(0.031)\end{array}$ \\
\hline Observations & 247,975 & 246,738 & 249,594 & 249,348 & 247,992 & 247,974 & 248,451 & 248,214 & 168,841 \\
\hline R-squared & 0.258 & 0.244 & 0.239 & 0.132 & 0.216 & 0.113 & 0.241 & 0.177 & 0.219 \\
\hline
\end{tabular}

Robust standard errors are reported in parentheses, clustered at the country level. ${ }^{* * *} \mathrm{p}<0.01,{ }^{* *} \mathrm{p}<0.05,{ }^{*} \mathrm{p}<0.1$

Notes: Dependent variables are dichotomous indicators as well as continuous variables (i.e. hours) for work supply in the last week.School attendance is a dichotomous variable referred to the last year. The sample includes children aged 5-14 in 38 countries. The table reports linear probability model results. Reference categories for reported dummy variables are 'higher education (i.e. more than primary)', 'female', 'female household's head', 'rural area'. Other controls include dummies for missing information on household head's education, wealth index, rural/urban area and country fixed effects. 
Table 7 - Migration relative skill composition (RSC) and child labor (largest sample)

$\begin{array}{lllll}(1) & \text { (2) (3) (4) (6) }\end{array}$

\begin{tabular}{|c|c|c|c|c|c|c|c|c|}
\hline Any work & $\begin{array}{l}\text { Total hours } \\
\text { of work }\end{array}$ & $\begin{array}{c}\text { Market } \\
\text { work }\end{array}$ & $\begin{array}{l}\text { Hours in } \\
\text { market } \\
\text { work }\end{array}$ & $\begin{array}{l}\text { (5) } \\
\text { Family } \\
\text { business }\end{array}$ & $\begin{array}{l}\text { Hours in } \\
\text { family } \\
\text { business }\end{array}$ & Chores & $\begin{array}{l}\text { Hours in } \\
\text { chores }\end{array}$ & $\begin{array}{c}\text { (y) } \\
\text { School } \\
\text { attendance }\end{array}$ \\
\hline
\end{tabular}

\begin{tabular}{|c|c|c|c|c|c|c|c|c|c|}
\hline $\begin{array}{l}\text { RSC*HhH low- } \\
\text { skill }\end{array}$ & $\begin{array}{c}-0.072 * * * \\
(0.020)\end{array}$ & $\begin{array}{c}-5.798 * * \\
(2.384)\end{array}$ & $\begin{array}{l}-0.068 * \\
(0.036)\end{array}$ & $\begin{array}{l}-2.387 \\
(1.560)\end{array}$ & $\begin{array}{l}-0.079 * \\
(0.041)\end{array}$ & $\begin{array}{l}-2.017 \\
(1.240)\end{array}$ & $\begin{array}{c}-0.068^{* * *} \\
(0.019)\end{array}$ & $\begin{array}{c}-2.095^{* * *} \\
(0.677)\end{array}$ & $\begin{array}{l}-0.005 \\
(0.026)\end{array}$ \\
\hline HhH low-skilled & $\begin{array}{c}0.029 * * * \\
(0.007)\end{array}$ & $\begin{array}{c}1.739 * * * \\
(0.617)\end{array}$ & $\begin{array}{l}0.027 * * \\
(0.010)\end{array}$ & $\begin{array}{c}0.704 \\
(0.432)\end{array}$ & $\begin{array}{c}0.030 * * \\
(0.012)\end{array}$ & $\begin{array}{c}0.442 \\
(0.316)\end{array}$ & $\begin{array}{l}0.029 * * * \\
(0.005)\end{array}$ & $\begin{array}{c}0.733^{* * *} \\
(0.191)\end{array}$ & $\begin{array}{c}-0.028 * * * \\
(0.008)\end{array}$ \\
\hline Age & $\begin{array}{c}0.045^{* * *} \\
(0.005)\end{array}$ & $\begin{array}{c}2.432 * * * \\
(0.195)\end{array}$ & $\begin{array}{c}0.033^{* * *} \\
(0.002)\end{array}$ & $\begin{array}{c}1.019 * * * \\
(0.104)\end{array}$ & $\begin{array}{c}0.030 * * * \\
(0.002)\end{array}$ & $\begin{array}{c}0.763 * * * \\
(0.087)\end{array}$ & $\begin{array}{c}0.040 * * * \\
(0.005)\end{array}$ & $\begin{array}{c}1.067 * * * \\
(0.106)\end{array}$ & $\begin{array}{c}0.040 * * * \\
(0.003)\end{array}$ \\
\hline Male & $\begin{array}{c}-0.078 * * * \\
(0.017)\end{array}$ & $\begin{array}{l}-0.579 \\
(0.405)\end{array}$ & $\begin{array}{c}0.035 * * * \\
(0.010)\end{array}$ & $\begin{array}{c}1.395^{* * *} \\
(0.347)\end{array}$ & $\begin{array}{c}0.035^{* * *} \\
(0.012)\end{array}$ & $\begin{array}{c}1.072 * * * \\
(0.339)\end{array}$ & $\begin{array}{c}-0.125^{* * * *} \\
(0.024)\end{array}$ & $\begin{array}{c}-2.806^{* * * *} \\
(0.446)\end{array}$ & $\begin{array}{l}0.016 * * \\
(0.007)\end{array}$ \\
\hline Ever in school & $\begin{array}{c}0.060 * * * \\
(0.010)\end{array}$ & $\begin{array}{l}-2.005^{* *} \\
(0.747)\end{array}$ & $\begin{array}{c}0.003 \\
(0.009)\end{array}$ & $\begin{array}{c}-1.434^{* * *} \\
(0.384)\end{array}$ & $\begin{array}{c}0.001 \\
(0.008)\end{array}$ & $\begin{array}{c}-1.111^{* * *} \\
(0.365)\end{array}$ & $\begin{array}{c}0.067 * * * \\
(0.010)\end{array}$ & $\begin{array}{l}-0.605^{*} \\
(0.355)\end{array}$ & $\begin{array}{c}0.614^{* * *} \\
(0.018)\end{array}$ \\
\hline HhH male & $\begin{array}{l}0.010 * \\
(0.005)\end{array}$ & $\begin{array}{c}0.962 * * * \\
(0.244)\end{array}$ & $\begin{array}{l}0.014^{* *} \\
(0.006)\end{array}$ & $\begin{array}{c}0.426^{* * *} \\
(0.125)\end{array}$ & $\begin{array}{c}0.020 * * * \\
(0.007)\end{array}$ & $\begin{array}{c}0.390 * * * \\
(0.129)\end{array}$ & $\begin{array}{l}0.012 * \\
(0.006)\end{array}$ & $\begin{array}{l}0.320^{*} \\
(0.158)\end{array}$ & $\begin{array}{l}-0.006 \\
(0.004)\end{array}$ \\
\hline $\begin{array}{l}\text { Mother lives at } \\
\text { home }\end{array}$ & $\begin{array}{c}-0.011^{* * *} \\
(0.004)\end{array}$ & $\begin{array}{l}-0.426 \\
(0.261)\end{array}$ & $\begin{array}{l}-0.000 \\
(0.006)\end{array}$ & $\begin{array}{l}-0.120 \\
(0.161)\end{array}$ & $\begin{array}{c}0.007 \\
(0.005)\end{array}$ & $\begin{array}{c}0.083 \\
(0.121)\end{array}$ & $\begin{array}{l}-0.005 \\
(0.004)\end{array}$ & $\begin{array}{c}-0.441^{* *} \\
(0.178)\end{array}$ & $\begin{array}{c}0.028 * * * \\
(0.006)\end{array}$ \\
\hline $\begin{array}{l}\text { Father lives at } \\
\text { home }\end{array}$ & $\begin{array}{l}-0.006 \\
(0.004)\end{array}$ & $\begin{array}{c}0.275 \\
(0.419)\end{array}$ & $\begin{array}{c}0.001 \\
(0.007)\end{array}$ & $\begin{array}{c}0.298 \\
(0.177)\end{array}$ & $\begin{array}{c}0.005 \\
(0.006)\end{array}$ & $\begin{array}{c}0.372 * * \\
(0.156)\end{array}$ & $\begin{array}{c}-0.009 * * \\
(0.004)\end{array}$ & $\begin{array}{l}-0.124 \\
(0.200)\end{array}$ & $\begin{array}{c}0.010 * * \\
(0.005)\end{array}$ \\
\hline $\begin{array}{l}\text { N. of siblings } \\
\text { aged 5-15 }\end{array}$ & $\begin{array}{l}-0.001 \\
(0.001)\end{array}$ & $\begin{array}{c}0.152 \\
(0.095)\end{array}$ & $\begin{array}{l}0.003 * \\
(0.002)\end{array}$ & $\begin{array}{c}0.096 \\
(0.066)\end{array}$ & $\begin{array}{c}0.003 * * \\
(0.002)\end{array}$ & $\begin{array}{c}0.070 \\
(0.056)\end{array}$ & $\begin{array}{c}-0.001 \\
(0.001)\end{array}$ & $\begin{array}{c}0.029 \\
(0.025)\end{array}$ & $\begin{array}{c}0.003 \\
(0.002)\end{array}$ \\
\hline $\begin{array}{l}\text { N. of children }<5 \\
\text { y.o. at home }\end{array}$ & $\begin{array}{l}0.004 * * \\
(0.001)\end{array}$ & $\begin{array}{l}0.196^{* *} \\
(0.094)\end{array}$ & $\begin{array}{l}0.002 * \\
(0.001)\end{array}$ & $\begin{array}{c}0.046 \\
(0.050)\end{array}$ & $\begin{array}{c}0.001 \\
(0.001)\end{array}$ & $\begin{array}{c}0.010 \\
(0.056)\end{array}$ & $\begin{array}{l}0.004^{* *} \\
(0.002)\end{array}$ & $\begin{array}{c}0.154^{* * *} \\
(0.048)\end{array}$ & $\begin{array}{c}-0.008^{* * *} \\
(0.003)\end{array}$ \\
\hline $\begin{array}{l}\text { N. of female } \\
\text { adults at home }\end{array}$ & $\begin{array}{c}-0.010 * * * \\
(0.002)\end{array}$ & $\begin{array}{c}-0.311^{* * *} \\
(0.100)\end{array}$ & $\begin{array}{l}-0.001 \\
(0.003)\end{array}$ & $\begin{array}{l}-0.081 \\
(0.070)\end{array}$ & $\begin{array}{l}-0.001 \\
(0.002)\end{array}$ & $\begin{array}{l}-0.100 * \\
(0.055)\end{array}$ & $\begin{array}{c}-0.008 * * * \\
(0.003)\end{array}$ & $\begin{array}{c}-0.246 * * * \\
(0.059)\end{array}$ & $\begin{array}{l}-0.000 \\
(0.001)\end{array}$ \\
\hline Household size & $\begin{array}{c}0.002 \\
(0.001)\end{array}$ & $\begin{array}{l}0.176^{*} \\
(0.090)\end{array}$ & $\begin{array}{c}0.002 \\
(0.002)\end{array}$ & $\begin{array}{c}0.086 \\
(0.056)\end{array}$ & $\begin{array}{c}0.002 \\
(0.002)\end{array}$ & $\begin{array}{l}0.100 * * \\
(0.043)\end{array}$ & $\begin{array}{c}0.000 \\
(0.001)\end{array}$ & $\begin{array}{c}0.044 \\
(0.035)\end{array}$ & $\begin{array}{c}0.000 \\
(0.001)\end{array}$ \\
\hline Birth order & $\begin{array}{l}-0.004 \\
(0.004)\end{array}$ & $\begin{array}{c}-0.685 * * * \\
(0.207)\end{array}$ & $\begin{array}{c}-0.008 * * * \\
(0.003)\end{array}$ & $\begin{array}{c}-0.296^{* *} \\
(0.111)\end{array}$ & $\begin{array}{c}-0.006^{* *} \\
(0.003)\end{array}$ & $\begin{array}{c}-0.214^{* *} \\
(0.091)\end{array}$ & $\begin{array}{c}-0.004 \\
(0.003)\end{array}$ & $\begin{array}{c}-0.320 * * * \\
(0.081)\end{array}$ & $\begin{array}{c}0.001 \\
(0.004)\end{array}$ \\
\hline Urban area & $\begin{array}{c}-0.052 * * * \\
(0.006)\end{array}$ & $\begin{array}{c}-5.355^{* * *} \\
(0.663)\end{array}$ & $\begin{array}{c}-0.123^{* * *} \\
(0.015)\end{array}$ & $\begin{array}{c}-2.591 * * * \\
(0.431)\end{array}$ & $\begin{array}{c}-0.132 * * * \\
(0.017)\end{array}$ & $\begin{array}{c}-2.512^{* * *} \\
(0.403)\end{array}$ & $\begin{array}{c}-0.032 * * * \\
(0.005)\end{array}$ & $\begin{array}{c}-1.144^{* * *} \\
(0.137)\end{array}$ & $\begin{array}{c}0.032 * * * \\
(0.007)\end{array}$ \\
\hline \multicolumn{10}{|l|}{ Wealth index } \\
\hline 1st quantile & $\begin{array}{c}0.074 * * * \\
(0.011)\end{array}$ & $\begin{array}{c}5.983^{* * *} \\
(0.616)\end{array}$ & $\begin{array}{c}0.129 * * * \\
(0.016)\end{array}$ & $\begin{array}{c}3.172 * * * \\
(0.463)\end{array}$ & $\begin{array}{c}0.134^{* * * *} \\
(0.018)\end{array}$ & $\begin{array}{c}2.619 * * * \\
(0.384)\end{array}$ & $\begin{array}{c}0.046^{* * *} \\
(0.010)\end{array}$ & $\begin{array}{c}1.370 * * * \\
(0.290)\end{array}$ & $\begin{array}{c}-0.103^{* * *} \\
(0.013)\end{array}$ \\
\hline 2nd quantile & $\begin{array}{c}0.053^{* * *} \\
(0.009)\end{array}$ & $\begin{array}{c}4.583^{* * *} \\
(0.777)\end{array}$ & $\begin{array}{c}0.099 * * * \\
(0.018)\end{array}$ & $\begin{array}{c}2.428 * * * \\
(0.507)\end{array}$ & $\begin{array}{c}0.104^{* * *} \\
(0.019)\end{array}$ & $\begin{array}{c}1.900 * * * \\
(0.436)\end{array}$ & $\begin{array}{c}0.038 * * * \\
(0.011)\end{array}$ & $\begin{array}{c}0.940 * * * \\
(0.266)\end{array}$ & $\begin{array}{c}-0.077 * * * \\
(0.014)\end{array}$ \\
\hline 3rd quantile & $\begin{array}{c}0.045^{* * *} \\
(0.009)\end{array}$ & $\begin{array}{c}3.696 * * * \\
(0.832)\end{array}$ & $\begin{array}{c}0.086^{* * *} \\
(0.019)\end{array}$ & $\begin{array}{c}1.859 * * * \\
(0.475)\end{array}$ & $\begin{array}{c}0.085^{* * *} \\
(0.020)\end{array}$ & $\begin{array}{c}1.370 * * * \\
(0.413)\end{array}$ & $\begin{array}{c}0.032^{* * *} \\
(0.009)\end{array}$ & $\begin{array}{c}0.796 * * * \\
(0.243)\end{array}$ & $\begin{array}{c}-0.050 * * * \\
(0.009)\end{array}$ \\
\hline 4th quantile & $\begin{array}{c}0.022^{* * *} \\
(0.008)\end{array}$ & $\begin{array}{c}2.247 * * * \\
(0.717)\end{array}$ & $\begin{array}{c}0.046^{* * *} \\
(0.014)\end{array}$ & $\begin{array}{c}1.123 * * \\
(0.417)\end{array}$ & $\begin{array}{c}0.050^{* * *} \\
(0.015)\end{array}$ & $\begin{array}{c}0.822 * * \\
(0.373)\end{array}$ & $\begin{array}{c}0.017 * * \\
(0.007)\end{array}$ & $\begin{array}{c}0.514^{* *} \\
(0.250)\end{array}$ & $\begin{array}{c}-0.032 * * * \\
(0.006)\end{array}$ \\
\hline Constant & $\begin{array}{c}0.292 * * * \\
(0.046)\end{array}$ & $\begin{array}{c}-7.696^{* * *} \\
(1.713)\end{array}$ & $\begin{array}{c}-0.071^{* * *} \\
(0.023)\end{array}$ & $\begin{array}{c}-5.473^{* * *} \\
(1.120)\end{array}$ & $\begin{array}{c}-0.124 * * * \\
(0.026)\end{array}$ & $\begin{array}{c}-4.292^{* * *} \\
(0.877)\end{array}$ & $\begin{array}{c}0.328 * * * \\
(0.046)\end{array}$ & $\begin{array}{c}0.057 \\
(0.840)\end{array}$ & $\begin{array}{c}-0.176^{* * *} \\
(0.031)\end{array}$ \\
\hline Observations & 247,975 & 246,738 & 249,594 & 249,348 & 247,992 & 247,974 & 248,451 & 248,214 & 168,841 \\
\hline R-squared & 0.258 & 0.245 & 0.239 & 0.132 & 0.216 & 0.113 & 0.241 & 0.177 & 0.219 \\
\hline
\end{tabular}

Robust standard errors are reported in parentheses, clustered at the country level. ${ }^{* * *} \mathrm{p}<0.01,{ }^{* *} \mathrm{p}<0.05,{ }^{*} \mathrm{p}<0.1$

Notes: Dependent variables are dichotomous indicators as well as continuous variables (i.e. hours) for work supply in the last week. School attendance is a dichotomous variable referred to the last year. The sample includes children aged 5-14 in 38 countries. The table reports linear probability model results. The Relative Skill Composition (RSC) index is the ratio of low-skilled to skilled labor in the migrant relative to the resident population. Reference categories for reported dummy variables are 'higher education', 'female', 'female household's head', 'rural area'. Other controls include dummies for missing information on household head's education, wealth index, rural/urban area and country fixed effects. 
Table 8 - Migration relative skill composition (RSC) and child labor (smallest sample)

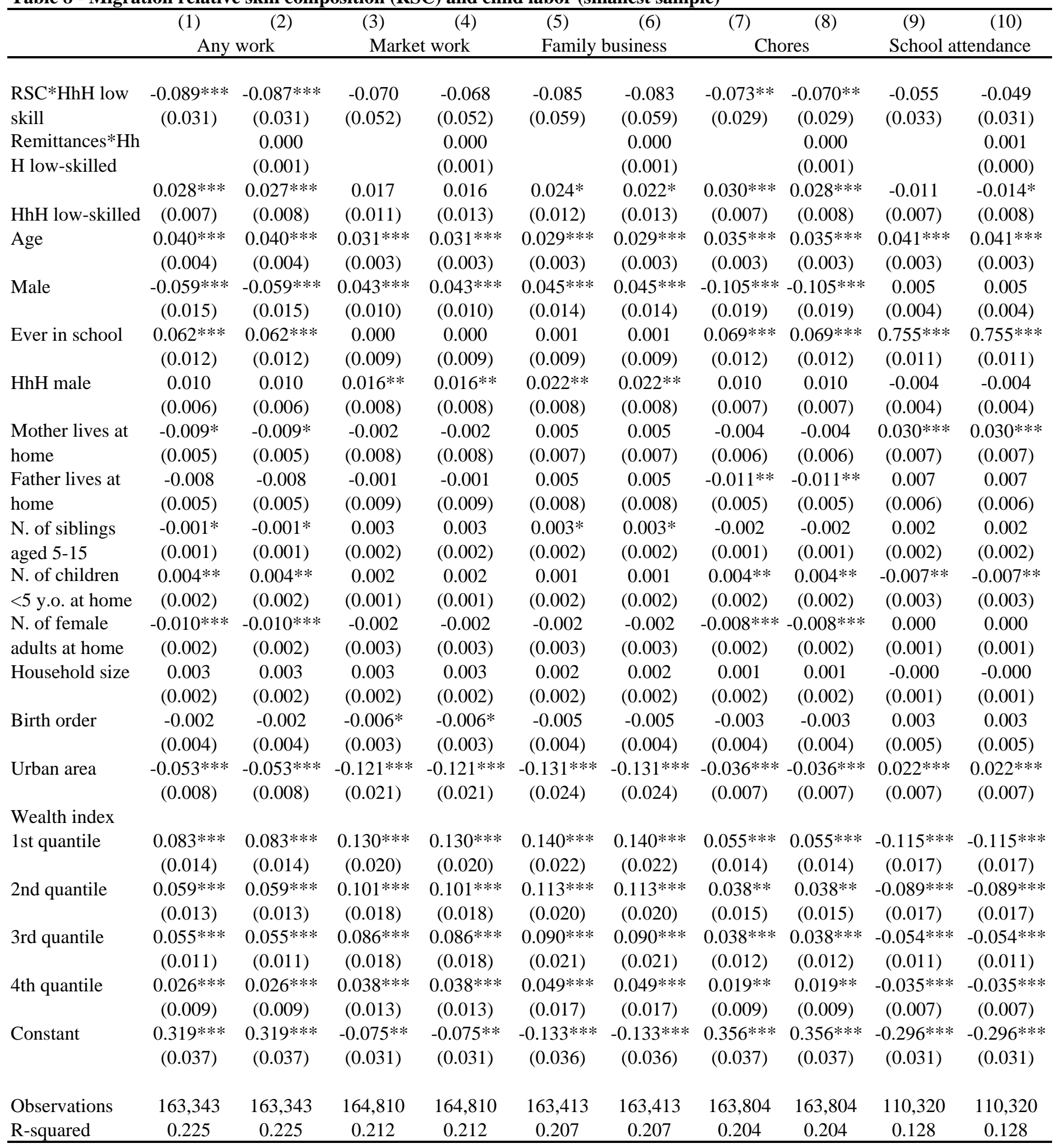

Robust standard errors are reported in parentheses, clustered at the country level. ${ }^{* * *} \mathrm{p}<0.01,{ }^{* *} \mathrm{p}<0.05,{ }^{*} \mathrm{p}<0.1$

Notes: Dependent variables are dichotomous indicators for work supply in the last week. School attendance is a dichotomous variable referred to the last year. The sample includes children aged 5-14 in 28 countries (i.e. those for which remittances are available). The table reports linear probability model results. The Relative Skill Composition (RSC) index is the ratio of low-skilled to skilled labor in the migrant relative to the resident population. Reference categories for reported dummy variables are 'higher education', 'female', 'female household's head', 'rural area'. Other controls include dummies for missing information on household head's education, wealth index, rural/urban area and country fixed effects. 
Table 9 - Child labor response to migration across urban-rural areas (largest sample)

\begin{tabular}{|c|c|c|c|c|c|c|c|c|c|}
\hline & Any work & $\begin{array}{c}\text { (2) } \\
\text { Total hours } \\
\text { of work }\end{array}$ & $\begin{array}{c}\text { (3) } \\
\text { Market } \\
\text { work }\end{array}$ & $\begin{array}{c}\text { (4) } \\
\text { Hours in } \\
\text { market } \\
\text { work } \\
\end{array}$ & $\begin{array}{c}\text { (5) } \\
\text { Family } \\
\text { business }\end{array}$ & $\begin{array}{c}\text { (6) } \\
\text { Hours in } \\
\text { family } \\
\text { business }\end{array}$ & Chores & $\begin{array}{c}\text { (8) } \\
\text { Hours in } \\
\text { chores }\end{array}$ & $\begin{array}{c}\text { (9) } \\
\text { School } \\
\text { attendance }\end{array}$ \\
\hline \multicolumn{10}{|c|}{ Panel A: Urban area } \\
\hline $\begin{array}{l}\text { RSC*HhH low- } \\
\text { skill }\end{array}$ & $\begin{array}{l}-0.063 * \\
(0.033)\end{array}$ & $\begin{array}{c}-4.210 * * \\
(1.589)\end{array}$ & $\begin{array}{l}-0.049 * \\
(0.027)\end{array}$ & $\begin{array}{l}-1.966^{*} \\
(0.980)\end{array}$ & $\begin{array}{c}-0.061^{* *} \\
(0.029)\end{array}$ & $\begin{array}{c}-1.518 * * \\
(0.662)\end{array}$ & $\begin{array}{c}-0.067 * * \\
(0.028)\end{array}$ & $\begin{array}{c}-1.315^{* *} \\
(0.594)\end{array}$ & $\begin{array}{l}-0.003 \\
(0.033)\end{array}$ \\
\hline HhH low-skilled & $\begin{array}{c}0.035 * * * \\
(0.010)\end{array}$ & $\begin{array}{c}1.777 * * * \\
(0.407)\end{array}$ & $\begin{array}{c}0.029 * * * \\
(0.009)\end{array}$ & $\begin{array}{l}0.836 * * \\
(0.311)\end{array}$ & $\begin{array}{c}0.032^{* * *} \\
(0.010)\end{array}$ & $\begin{array}{l}0.570 * * \\
(0.209)\end{array}$ & $\begin{array}{c}0.035^{* * *} \\
(0.008)\end{array}$ & $\begin{array}{c}0.639 * * * \\
(0.193)\end{array}$ & $\begin{array}{c}-0.028^{* *} \\
(0.011)\end{array}$ \\
\hline Constant & $\begin{array}{c}0.265^{* * *} \\
(0.044)\end{array}$ & $\begin{array}{c}-5.209 * * * \\
(1.748)\end{array}$ & $\begin{array}{l}-0.061 * \\
(0.031)\end{array}$ & $\begin{array}{c}-3.219 * * * \\
(0.921)\end{array}$ & $\begin{array}{c}-0.116^{* * *} \\
(0.040)\end{array}$ & $\begin{array}{c}-2.380 * * * \\
(0.706)\end{array}$ & $\begin{array}{c}0.287 * * * \\
(0.046)\end{array}$ & $\begin{array}{l}-0.149 \\
(0.772)\end{array}$ & $\begin{array}{c}-0.257 * * * \\
(0.031)\end{array}$ \\
\hline Observations & 88,334 & 87,870 & 88,874 & 88,706 & 88,333 & 88,333 & 88,529 & 88,462 & 70,214 \\
\hline R-squared & 0.266 & 0.204 & 0.204 & 0.089 & 0.153 & 0.071 & 0.252 & 0.175 & 0.182 \\
\hline \multicolumn{10}{|c|}{ Panel B: Rural area } \\
\hline $\begin{array}{l}\text { RSC*HhH low- } \\
\text { skill }\end{array}$ & $\begin{array}{c}-0.092 * * * \\
(0.024)\end{array}$ & $\begin{array}{l}-5.358^{*} \\
(2.809)\end{array}$ & $\begin{array}{l}-0.052 \\
(0.037)\end{array}$ & $\begin{array}{l}-1.504 \\
(1.766)\end{array}$ & $\begin{array}{l}-0.061 \\
(0.040)\end{array}$ & $\begin{array}{l}-1.307 \\
(1.460)\end{array}$ & $\begin{array}{c}-0.086^{* * *} \\
(0.024)\end{array}$ & $\begin{array}{l}-2.683^{* *} \\
(1.020)\end{array}$ & $\begin{array}{l}-0.021 \\
(0.028)\end{array}$ \\
\hline HhH low-skilled & $\begin{array}{c}0.030^{* * *} \\
(0.007)\end{array}$ & $\begin{array}{l}1.739 * * \\
(0.708)\end{array}$ & $\begin{array}{l}0.022 * \\
(0.011)\end{array}$ & $\begin{array}{c}0.569 \\
(0.433)\end{array}$ & $\begin{array}{l}0.025 * * \\
(0.011)\end{array}$ & $\begin{array}{c}0.339 \\
(0.323)\end{array}$ & $\begin{array}{c}0.028 * * * \\
(0.006)\end{array}$ & $\begin{array}{c}0.845^{* * *} \\
(0.252)\end{array}$ & $\begin{array}{l}-0.024^{* *} \\
(0.010)\end{array}$ \\
\hline Constant & $\begin{array}{c}0.282 * * * \\
(0.054)\end{array}$ & $\begin{array}{c}-11.459 * * * \\
(2.418)\end{array}$ & $\begin{array}{c}-0.131 * * * \\
(0.044)\end{array}$ & $\begin{array}{c}-8.073 * * * \\
(1.660)\end{array}$ & $\begin{array}{c}-0.190 * * * \\
(0.040)\end{array}$ & $\begin{array}{c}-6.803^{* * *} \\
(1.445)\end{array}$ & $\begin{array}{c}0.335^{* * *} \\
(0.048)\end{array}$ & $\begin{array}{l}-0.158 \\
(0.957)\end{array}$ & $\begin{array}{c}-0.110 * * * \\
(0.039)\end{array}$ \\
\hline Observations & 159,641 & 158,868 & 160,720 & 160,642 & 159,659 & 159,641 & 159,922 & 159,752 & 98,627 \\
\hline R-squared & 0.251 & 0.249 & 0.241 & 0.141 & 0.220 & 0.120 & 0.235 & 0.175 & 0.236 \\
\hline
\end{tabular}

Robust standard errors are reported in parentheses, clustered at the country level. ${ }^{* * *} \mathrm{p}<0.01,{ }^{* *} \mathrm{p}<0.05$, $^{*} \mathrm{p}<0.1$

Notes: Dependent variables are dichotomous indicators as well as continuous variables (i.e. hours) for work supply in the last week. School attendance is a dichotomous variable referred to the last year. The sample includes children aged 5-14 in 38 countries. The table reports linear probability model results. The Relative Skill Composition (RSC) index is the log of the ratio of low-skilled to skilled labor in the migrant relative to the resident population. Other controls are as in Table 4. 
Table 10 - Child labor response to migration by child age (largest sample)

\begin{tabular}{|c|c|c|c|c|c|c|c|c|c|}
\hline & $\begin{array}{c}\text { (1) } \\
\text { Any work }\end{array}$ & $\begin{array}{c}\text { (2) } \\
\text { Total hours } \\
\text { of work }\end{array}$ & $\begin{array}{c}\text { (3) } \\
\text { Market } \\
\text { work }\end{array}$ & $\begin{array}{c}(4) \\
\text { Hours in } \\
\text { market } \\
\text { work }\end{array}$ & $\begin{array}{c}\text { (5) } \\
\text { Family } \\
\text { business }\end{array}$ & $\begin{array}{c}(6) \\
\text { Hours in } \\
\text { family } \\
\text { business }\end{array}$ & Chores & $\begin{array}{c}(8) \\
\text { Hours in } \\
\text { chores }\end{array}$ & $\begin{array}{c}\text { (9) } \\
\text { School } \\
\text { attendance }\end{array}$ \\
\hline RSC*HhH low-skill & $\begin{array}{c}-0.106 * * * \\
(0.026)\end{array}$ & $\begin{array}{c}-5.772 * * * \\
(1.958)\end{array}$ & $\begin{array}{c}-0.102 * * \\
(0.043)\end{array}$ & $\begin{array}{c}-2.354^{*} \\
(1.196)\end{array}$ & $\begin{array}{c}-0.105 * * \\
(0.044)\end{array}$ & $\begin{array}{l}-1.939 * \\
(1.026)\end{array}$ & $\begin{array}{c}-0.091 * * * \\
(0.022)\end{array}$ & $\begin{array}{c}-1.948^{* * *} \\
(0.514)\end{array}$ & $\begin{array}{c}0.022 \\
(0.025)\end{array}$ \\
\hline HhH low-skilled & $\begin{array}{c}0.036^{* * *} \\
(0.007)\end{array}$ & $\begin{array}{c}1.442^{* * * *} \\
(0.507)\end{array}$ & $\begin{array}{c}0.030 * * * \\
(0.010)\end{array}$ & $\begin{array}{c}0.532 \\
(0.318)\end{array}$ & $\begin{array}{c}0.034^{* * *} \\
(0.011)\end{array}$ & $\begin{array}{c}0.339 \\
(0.250)\end{array}$ & $\begin{array}{c}0.035^{* * *} \\
(0.007)\end{array}$ & $\begin{array}{c}0.568 * * * \\
(0.143)\end{array}$ & $\begin{array}{c}-0.036^{* * *} \\
(0.006)\end{array}$ \\
\hline Constant & $\begin{array}{c}0.107^{* * *} \\
(0.033)\end{array}$ & $\begin{array}{c}-9.106^{* * *} \\
(2.055)\end{array}$ & $\begin{array}{c}-0.086 * * * \\
(0.031)\end{array}$ & $\begin{array}{c}-4.608 * * * \\
(1.255)\end{array}$ & $\begin{array}{c}-0.146 * * * \\
(0.037)\end{array}$ & $\begin{array}{c}-4.118 * * * \\
(0.992)\end{array}$ & $\begin{array}{c}0.128 * * * \\
(0.036)\end{array}$ & $\begin{array}{c}-2.120 * * * \\
(0.730)\end{array}$ & $\begin{array}{c}-0.558 * * * \\
(0.096)\end{array}$ \\
\hline Observations & 142,677 & 142,136 & 143,793 & 143,665 & 142,780 & 142,777 & 143,098 & 143,004 & 80,239 \\
\hline R-squared & 0.269 & 0.186 & 0.232 & 0.098 & 0.196 & 0.081 & 0.251 & 0.142 & 0.284 \\
\hline \multicolumn{10}{|c|}{ Panel B: Children aged 10-14 } \\
\hline Constant & $\begin{array}{c}0.701^{* * *} \\
(0.037)\end{array}$ & $\begin{array}{c}0.226 \\
(2.706)\end{array}$ & $\begin{array}{c}0.052 \\
(0.043)\end{array}$ & $\begin{array}{c}-4.690 * * \\
(1.890)\end{array}$ & $\begin{array}{c}0.003 \\
(0.039)\end{array}$ & $\begin{array}{c}-2.828 * * \\
(1.355)\end{array}$ & $\begin{array}{c}0.746 * * * \\
(0.027)\end{array}$ & $\begin{array}{c}6.021^{* * *} \\
(0.828)\end{array}$ & $\begin{array}{c}0.292^{* * *} \\
(0.073)\end{array}$ \\
\hline Observations & 105,298 & 104,602 & 105,801 & 105,683 & 105,212 & 105,197 & 105,353 & 105,210 & 88,602 \\
\hline R-squared & 0.163 & 0.231 & 0.219 & 0.141 & 0.211 & 0.127 & 0.185 & 0.154 & 0.134 \\
\hline
\end{tabular}

Robust standard errors are reported in parentheses, clustered at the country level. ${ }^{* * *} \mathrm{p}<0.01,{ }^{* *} \mathrm{p}<0.05,{ }^{*} \mathrm{p}<0.1$

Notes: Dependent variables are dichotomous indicators as well as continuous variables (i.e. hours) for work supply in the last week. School attendance is a dichotomous variable referred to the last year. The sample includes children aged 5-14 in 38 countries. The table reports linear probability model results. The Relative Skill Composition (RSC) index is the log of the ratio of low-skilled to skilled labor in the migrant relative to the resident population. Other controls are as in Table 4 with the exception of col.(9)-Panel A where we dropped the 'ever in school' control. 
Table 11 - Child labor response to migration by child gender (largest sample)

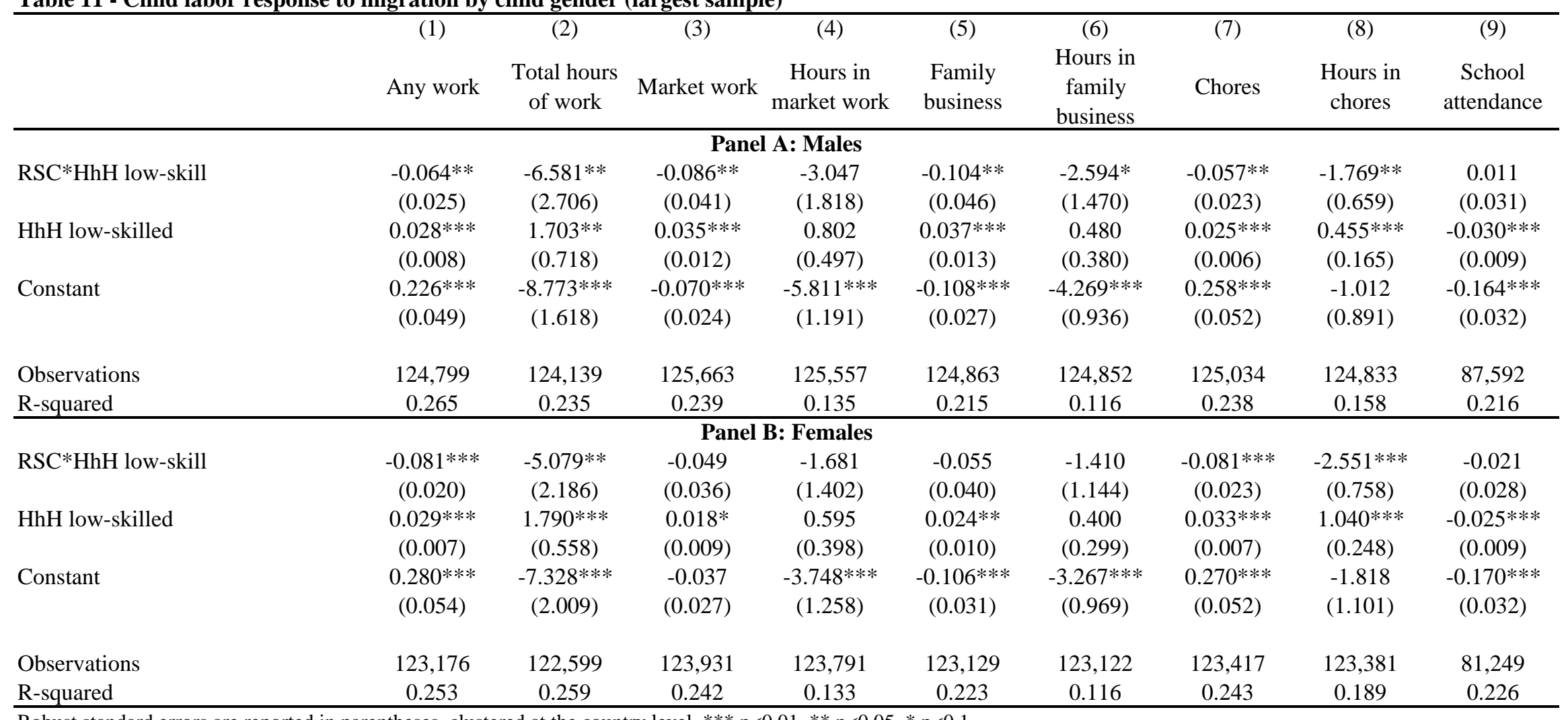

Robust standard errors are reported in parentheses, clustered at the country level. ${ }^{* * *} \mathrm{p}<0.01,{ }^{* *} \mathrm{p}<0.05,{ }^{*} \mathrm{p}<0.1$

Notes: Dependent variables are dichotomous indicators as well as continuous variables (i.e. hours) for work supply in the last week. School attendance is a dichotomous variable referred to the last year. The sample includes children aged 5-14 in 38 countries. The table reports linear probability model results. The Relative Skill Composition (RSC) index is the log of the ratio of low-skilled to skilled labor in the migrant relative to the resident population. Other controls are as in Table 4. 
Table 12 - Child labor response to migration by household wealth (largest sample)

\begin{tabular}{|c|c|c|c|c|c|c|c|c|c|}
\hline & $\begin{array}{c}\text { (1) } \\
\text { Any work }\end{array}$ & $\begin{array}{c}(2) \\
\text { Total hours } \\
\text { of work }\end{array}$ & Market work & $\begin{array}{c}\text { (4) } \\
\text { Hours in } \\
\text { market work }\end{array}$ & $\begin{array}{c}\text { (5) } \\
\text { Family } \\
\text { business }\end{array}$ & $\begin{array}{c}(6) \\
\text { Hours in } \\
\text { family } \\
\text { business }\end{array}$ & Chores & $\begin{array}{c}\text { (8) } \\
\text { Hours in } \\
\text { chores }\end{array}$ & $\begin{array}{c}\text { (9) } \\
\text { School } \\
\text { attendance }\end{array}$ \\
\hline \multicolumn{10}{|c|}{ Panel A: Poorest wealth quintiles } \\
\hline RSC*HhH low-skill & $\begin{array}{c}-0.115^{* * *} \\
(0.027)\end{array}$ & $\begin{array}{c}-5.162 \\
(3.383)\end{array}$ & $\begin{array}{c}-0.112^{* *} \\
(0.054)\end{array}$ & $\begin{array}{c}-1.711 \\
(2.314)\end{array}$ & $\begin{array}{c}-0.123^{* *} \\
(0.056)\end{array}$ & $\begin{array}{c}-1.620 \\
(1.909)\end{array}$ & $\begin{array}{c}-0.093 * * * \\
(0.028)\end{array}$ & $\begin{array}{c}-2.151^{*} \\
(1.063)\end{array}$ & $\begin{array}{l}-0.011 \\
(0.038)\end{array}$ \\
\hline HhH low-skilled & $\begin{array}{c}0.035 * * * \\
(0.007)\end{array}$ & $\begin{array}{l}1.672 * \\
(0.880)\end{array}$ & $\begin{array}{c}0.029 * * \\
(0.014)\end{array}$ & $\begin{array}{c}0.591 \\
(0.533)\end{array}$ & $\begin{array}{c}0.036 * * \\
(0.014)\end{array}$ & $\begin{array}{c}0.437 \\
(0.427)\end{array}$ & $\begin{array}{c}0.032 * * * \\
(0.007)\end{array}$ & $\begin{array}{c}0.771 * * * \\
(0.281)\end{array}$ & $\begin{array}{c}-0.025^{* *} \\
(0.012)\end{array}$ \\
\hline Constant & $\begin{array}{c}0.346 * * * \\
(0.053)\end{array}$ & $\begin{array}{c}-8.599 * * * \\
(2.060)\end{array}$ & $\begin{array}{c}-0.057 \\
(0.042)\end{array}$ & $\begin{array}{c}-6.944 * * * \\
(1.374)\end{array}$ & $\begin{array}{c}-0.071^{* *} \\
(0.033)\end{array}$ & $\begin{array}{c}-5.736 * * * \\
(1.254)\end{array}$ & $\begin{array}{c}0.394 * * * \\
(0.047)\end{array}$ & $\begin{array}{c}0.410 \\
(0.992)\end{array}$ & $\begin{array}{c}-0.174 * * * \\
(0.041)\end{array}$ \\
\hline Observations & 107,933 & 107,355 & 108,598 & 108,525 & 107,925 & 107,918 & 108,097 & 107,963 & 61,630 \\
\hline R-squared & 0.249 & 0.245 & 0.237 & 0.139 & 0.215 & 0.119 & 0.238 & 0.171 & 0.221 \\
\hline \multicolumn{10}{|c|}{ Panel B: Richest wealth quintiles } \\
\hline RSC*HhH low-skill & $\begin{array}{l}-0.037 \\
(0.023)\end{array}$ & $\begin{array}{c}-5.901^{* *} \\
(2.541)\end{array}$ & $\begin{array}{l}-0.069 \\
(0.044)\end{array}$ & $\begin{array}{l}-2.701^{*} \\
(1.410)\end{array}$ & $\begin{array}{l}-0.059 \\
(0.053)\end{array}$ & $\begin{array}{c}-1.734 \\
(1.037)\end{array}$ & $\begin{array}{l}-0.037 \\
(0.024)\end{array}$ & $\begin{array}{c}-2.051^{* * *} \\
(0.688)\end{array}$ & $\begin{array}{l}-0.013 \\
(0.028)\end{array}$ \\
\hline HhH low-skilled & $\begin{array}{c}0.022^{* * *} \\
(0.006)\end{array}$ & $\begin{array}{c}1.585 * * \\
(0.615)\end{array}$ & $\begin{array}{l}0.026^{*} \\
(0.014)\end{array}$ & $\begin{array}{l}0.822 * \\
(0.414)\end{array}$ & $\begin{array}{c}0.026 \\
(0.017)\end{array}$ & $\begin{array}{c}0.427 \\
(0.319)\end{array}$ & $\begin{array}{c}0.024^{* * *} \\
(0.005)\end{array}$ & $\begin{array}{c}0.537 * * \\
(0.215)\end{array}$ & $\begin{array}{c}-0.030 * * * \\
(0.007)\end{array}$ \\
\hline Constant & $\begin{array}{c}0.322 * * * \\
(0.056)\end{array}$ & $\begin{array}{c}-0.187 \\
(1.616)\end{array}$ & $\begin{array}{c}0.045 \\
(0.032)\end{array}$ & $\begin{array}{l}-0.422 \\
(0.795)\end{array}$ & $\begin{array}{c}-0.023 \\
(0.034)\end{array}$ & $\begin{array}{l}-0.339 \\
(0.663)\end{array}$ & $\begin{array}{c}0.322 * * * \\
(0.054)\end{array}$ & $\begin{array}{c}1.079 \\
(0.864)\end{array}$ & $\begin{array}{c}-0.239 * * * \\
(0.026)\end{array}$ \\
\hline Observations & 83,872 & 83,519 & 84,464 & 84,357 & 83,914 & 83,906 & 84,098 & 84,048 & 65,513 \\
\hline R-squared & 0.276 & 0.229 & 0.225 & 0.107 & 0.180 & 0.089 & 0.255 & 0.181 & 0.204 \\
\hline
\end{tabular}

Robust standard errors are reported in parentheses, clustered at the country level. ${ }^{* * *} \mathrm{p}<0.01,{ }^{* *} \mathrm{p}<0.05,{ }^{*} \mathrm{p}<0.1$

Notes: Dependent variables are dichotomous indicators as well as continuous variables (i.e. hours) for work supply in the last week. School attendance is a dichotomous variable referred to the last year. The sample includes children aged 5-14 in 38 countries. The table reports linear probability model results. The Relative Skill Composition (RSC) index is the log of the ratio of low-skilled to skilled labor in the migrant relative to the resident population. Other controls are as in Table 4. 
Table 13 - Child labor response to female emigration shock (largest sample)

\begin{tabular}{|c|c|c|c|c|c|c|c|c|c|}
\hline & $\begin{array}{c}\text { (1) } \\
\text { Any work }\end{array}$ & $\begin{array}{c}\text { (2) } \\
\text { Total hours } \\
\text { of work }\end{array}$ & Market work & $\begin{array}{c}\text { (4) } \\
\text { Hours in } \\
\text { market work }\end{array}$ & $\begin{array}{c}\text { (5) } \\
\text { Family } \\
\text { business }\end{array}$ & $\begin{array}{c}(6) \\
\text { Hours in } \\
\text { family } \\
\text { business } \\
\end{array}$ & Chores & $\begin{array}{c}(8) \\
\text { Hours in } \\
\text { chores }\end{array}$ & $\begin{array}{c}\text { (9) } \\
\text { School } \\
\text { attendance }\end{array}$ \\
\hline \multicolumn{10}{|c|}{ Panel A: Full sample } \\
\hline RSC_female*HhH low-skill & $\begin{array}{c}-0.087^{* * *} \\
(0.026)\end{array}$ & $\begin{array}{c}-6.810^{* *} \\
(3.180)\end{array}$ & $\begin{array}{c}-0.075 \\
(0.050)\end{array}$ & $\begin{array}{l}-3.119 \\
(2.183)\end{array}$ & $\begin{array}{c}-0.084 \\
(0.055)\end{array}$ & $\begin{array}{c}-2.661 \\
(1.830)\end{array}$ & $\begin{array}{c}-0.078^{* * *} \\
(0.021)\end{array}$ & $\begin{array}{c}-2.233^{* * *} \\
(0.777)\end{array}$ & $\begin{array}{c}0.005 \\
(0.029)\end{array}$ \\
\hline HhH low-skilled & $\begin{array}{c}0.029 * * * \\
(0.007)\end{array}$ & $\begin{array}{c}1.732 * * * \\
(0.622)\end{array}$ & $\begin{array}{l}0.026 * * \\
(0.011)\end{array}$ & $\begin{array}{l}0.743^{*} \\
(0.426)\end{array}$ & $\begin{array}{l}0.029 * * \\
(0.012)\end{array}$ & $\begin{array}{c}0.480 \\
(0.320)\end{array}$ & $\begin{array}{c}0.029 * * * \\
(0.006)\end{array}$ & $\begin{array}{c}0.700^{* * *} \\
(0.193)\end{array}$ & $\begin{array}{c}-0.029 * * * \\
(0.008)\end{array}$ \\
\hline Constant & $\begin{array}{c}0.292 * * * \\
(0.046)\end{array}$ & $\begin{array}{c}-7.682 * * * \\
(1.711)\end{array}$ & $\begin{array}{c}-0.071^{* * *} \\
(0.023)\end{array}$ & $\begin{array}{c}-5.466^{* * *} \\
(1.118)\end{array}$ & $\begin{array}{c}-0.124^{* * *} \\
(0.026)\end{array}$ & $\begin{array}{c}-4.286 * * * \\
(0.876)\end{array}$ & $\begin{array}{c}0.328 * * * \\
(0.046)\end{array}$ & $\begin{array}{c}0.061 \\
(0.838)\end{array}$ & $\begin{array}{c}-0.176^{* * *} \\
(0.031)\end{array}$ \\
\hline $\begin{array}{l}\text { Observations } \\
\text { R-squared }\end{array}$ & $\begin{array}{c}247,975 \\
0.258 \\
\end{array}$ & $\begin{array}{c}246,738 \\
0.245 \\
\end{array}$ & $\begin{array}{c}249,594 \\
0.239 \\
\end{array}$ & $\begin{array}{c}249,348 \\
0.132 \\
\end{array}$ & $\begin{array}{c}247,992 \\
0.216\end{array}$ & $\begin{array}{c}247,974 \\
0.113\end{array}$ & $\begin{array}{c}248,451 \\
0.241\end{array}$ & $\begin{array}{c}248,214 \\
0.177\end{array}$ & $\begin{array}{c}168,841 \\
0.219\end{array}$ \\
\hline \multicolumn{10}{|c|}{ Panel B: Female headed households } \\
\hline RSC_female*HhH low-skill & $\begin{array}{c}-0.165^{* * *} \\
(0.040)\end{array}$ & $\begin{array}{c}-0.272 \\
(2.387)\end{array}$ & $\begin{array}{c}-0.110^{*} \\
(0.062)\end{array}$ & $\begin{array}{c}2.541 \\
(1.577)\end{array}$ & $\begin{array}{c}-0.037 \\
(0.046)\end{array}$ & $\begin{array}{l}1.848^{*} \\
(1.043)\end{array}$ & $\begin{array}{c}-0.162 * * * \\
(0.038)\end{array}$ & $\begin{array}{l}-2.675 \\
(1.852)\end{array}$ & $\begin{array}{l}-0.004 \\
(0.034)\end{array}$ \\
\hline HhH low-skilled & $\begin{array}{c}0.044 * * * \\
(0.011)\end{array}$ & $\begin{array}{c}0.271 \\
(0.550)\end{array}$ & $\begin{array}{c}0.006 \\
(0.017)\end{array}$ & $\begin{array}{c}-0.327 \\
(0.337)\end{array}$ & $\begin{array}{l}-0.007 \\
(0.012)\end{array}$ & $\begin{array}{l}-0.338 \\
(0.207)\end{array}$ & $\begin{array}{c}0.051^{* * *} \\
(0.012)\end{array}$ & $\begin{array}{c}0.609 \\
(0.490)\end{array}$ & $\begin{array}{c}-0.007 \\
(0.010)\end{array}$ \\
\hline Constant & $\begin{array}{c}0.345^{* * *} \\
(0.047)\end{array}$ & $\begin{array}{c}-5.042 * * \\
(2.246)\end{array}$ & $\begin{array}{l}-0.053 \\
(0.032)\end{array}$ & $\begin{array}{c}-3.864^{* * *} \\
(1.374)\end{array}$ & $\begin{array}{c}-0.082^{* *} \\
(0.034)\end{array}$ & $\begin{array}{c}-2.163^{* *} \\
(0.843)\end{array}$ & $\begin{array}{c}0.368 * * * \\
(0.048)\end{array}$ & $\begin{array}{l}-0.118 \\
(1.057)\end{array}$ & $\begin{array}{l}-0.082 * \\
(0.041)\end{array}$ \\
\hline Observations & 25,941 & 25,814 & 26,209 & 26,159 & 25,995 & 25,993 & 26,042 & 26,033 & 19,377 \\
\hline R-squared & 0.246 & 0.220 & 0.212 & 0.113 & 0.188 & 0.098 & 0.224 & 0.167 & 0.200 \\
\hline \multicolumn{10}{|c|}{ Panel C: Male headed households } \\
\hline RSC_female*HhH low-skill & $\begin{array}{c}-0.077 * * * \\
(0.028)\end{array}$ & $\begin{array}{c}-7.861^{* *} \\
(3.549)\end{array}$ & $\begin{array}{l}-0.068 \\
(0.055)\end{array}$ & $\begin{array}{l}-4.044 \\
(2.486)\end{array}$ & $\begin{array}{l}-0.088 \\
(0.060)\end{array}$ & $\begin{array}{l}-3.449 \\
(2.134)\end{array}$ & $\begin{array}{c}-0.069 * * * \\
(0.024)\end{array}$ & $\begin{array}{c}-2.135 * * * \\
(0.765)\end{array}$ & $\begin{array}{c}0.001 \\
(0.032)\end{array}$ \\
\hline HhH low-skilled & $\begin{array}{c}0.027^{* * *} \\
(0.007)\end{array}$ & $\begin{array}{c}1.886 * * * \\
(0.659)\end{array}$ & $\begin{array}{l}0.027 * * \\
(0.011)\end{array}$ & $\begin{array}{l}0.864^{*} \\
(0.442)\end{array}$ & $\begin{array}{l}0.032 * * \\
(0.013)\end{array}$ & $\begin{array}{l}0.573 * \\
(0.338)\end{array}$ & $\begin{array}{c}0.026^{* * *} \\
(0.006)\end{array}$ & $\begin{array}{c}0.700^{* * *} \\
(0.203)\end{array}$ & $\begin{array}{c}-0.031^{* * *} \\
(0.009)\end{array}$ \\
\hline Constant & $\begin{array}{c}0.297 * * * \\
(0.046)\end{array}$ & $\begin{array}{c}-7.019 * * * \\
(1.571)\end{array}$ & $\begin{array}{c}-0.061^{* *} \\
(0.024)\end{array}$ & $\begin{array}{c}-5.222 * * * \\
(1.047)\end{array}$ & $\begin{array}{c}-0.110^{* * *} \\
(0.026)\end{array}$ & $\begin{array}{c}-4.146^{* * * *} \\
(0.822)\end{array}$ & $\begin{array}{c}0.335 * * * \\
(0.046)\end{array}$ & $\begin{array}{c}0.401 \\
(0.827)\end{array}$ & $\begin{array}{c}-0.197 * * * \\
(0.032)\end{array}$ \\
\hline Observations & 222,013 & 220,903 & 223,364 & 223,168 & 221,976 & 221,960 & 222,388 & 222,160 & 149,448 \\
\hline R-squared & 0.260 & 0.247 & 0.243 & 0.133 & 0.219 & 0.114 & 0.244 & 0.178 & 0.221 \\
\hline
\end{tabular}

Robust standard errors are reported in parentheses, clustered at the country level. *** $\mathrm{p}<0.01, * * \mathrm{p}<0.05, * \mathrm{p}<0.1$

Notes: Dependent variables are dichotomous indicators as well as continuous variables (i.e. hours) for work supply in the last week. School attendance is a dichotomous variable referred to the last year. The sample includes children aged 5-14 in 38 countries. The table reports linear probability model results. The Relative Skill Composition (RSC) index is the log of the ratio of low-skilled to skilled labor in the migrant relative to the resident population. Other controls are as in Table 4. 
Table 14 - Child labor response to male emigration shock (largest sample)

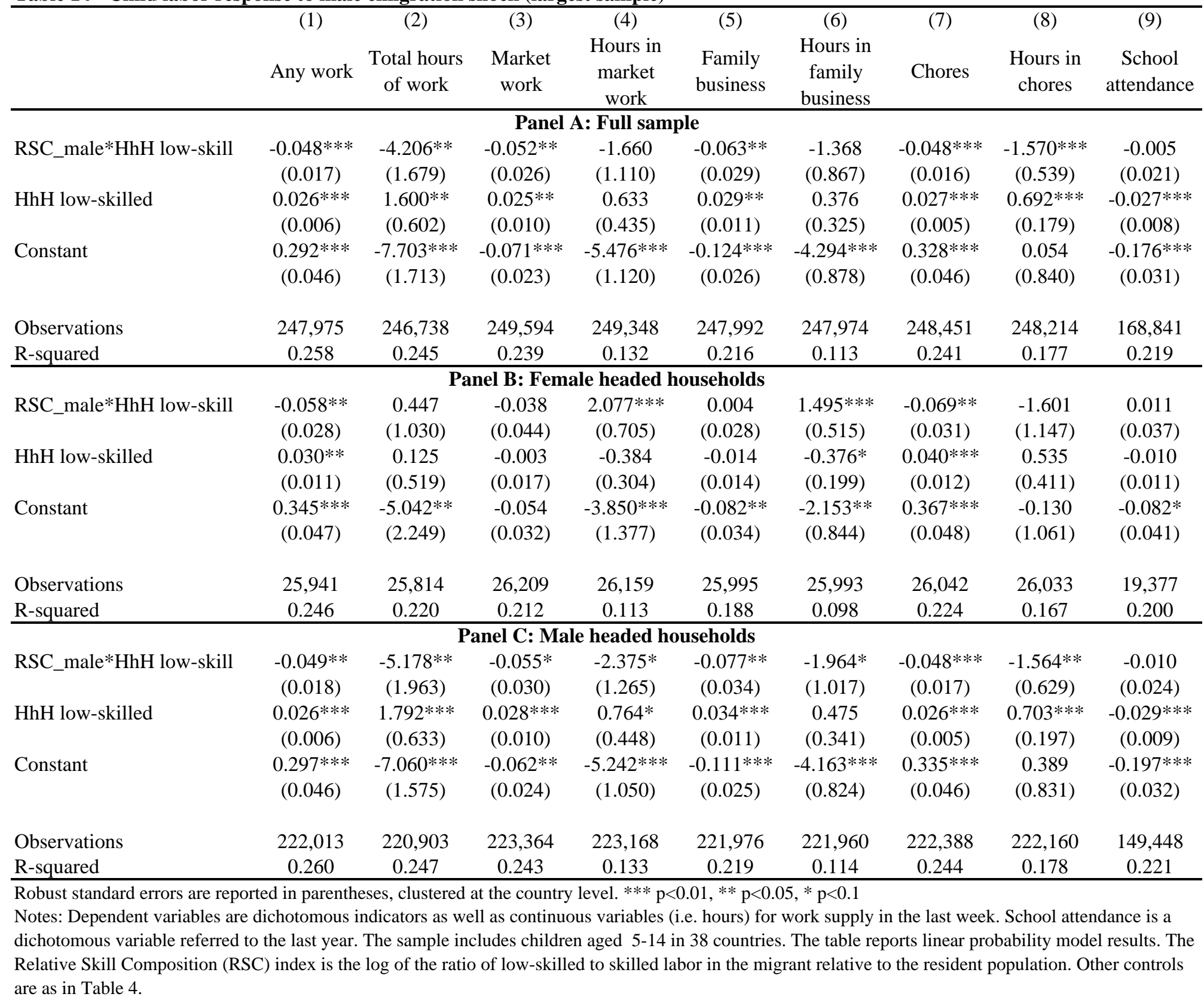


Table 15 - Migration outflows and child labor (Migration data from Docquier et al. 2010)

\begin{tabular}{|c|c|c|c|c|c|c|c|c|c|}
\hline & Any work & $\begin{array}{c}(2) \\
\text { Total hours } \\
\text { of work }\end{array}$ & $\begin{array}{c}\text { (3) } \\
\text { Market } \\
\text { work }\end{array}$ & $\begin{array}{c}(4) \\
\text { Hours in } \\
\text { market } \\
\text { work }\end{array}$ & $\begin{array}{c}\text { (5) } \\
\text { Family } \\
\text { business }\end{array}$ & $\begin{array}{c}\text { (6) } \\
\text { Hours in } \\
\text { family } \\
\text { business }\end{array}$ & Chores & $\begin{array}{c}\text { (8) } \\
\text { Hours in } \\
\text { chores }\end{array}$ & $\begin{array}{c}\text { (9) } \\
\text { School } \\
\text { attendance }\end{array}$ \\
\hline $\begin{array}{l}\text { Mig. rate*HhH } \\
\text { low-skill }\end{array}$ & $\begin{array}{c}-0.086^{* * *} \\
(0.025)\end{array}$ & $\begin{array}{c}-8.603 * * \\
(3.458)\end{array}$ & $\begin{array}{l}-0.053 \\
(0.050)\end{array}$ & $\begin{array}{l}-3.496 * \\
(1.728)\end{array}$ & $\begin{array}{l}-0.081 \\
(0.056)\end{array}$ & $\begin{array}{l}-3.214^{*} \\
(1.587)\end{array}$ & $\begin{array}{c}-0.086^{* * *} \\
(0.026)\end{array}$ & $\begin{array}{c}-3.262^{* * *} \\
(1.108)\end{array}$ & $\begin{array}{c}0.041 \\
(0.026)\end{array}$ \\
\hline HhH low-skilled & $\begin{array}{c}0.023^{* * *} \\
(0.006)\end{array}$ & $\begin{array}{c}0.689 \\
(0.596)\end{array}$ & $\begin{array}{c}0.012 \\
(0.009)\end{array}$ & $\begin{array}{c}0.188 \\
(0.407)\end{array}$ & $\begin{array}{c}0.013 \\
(0.011)\end{array}$ & $\begin{array}{c}0.038 \\
(0.335)\end{array}$ & $\begin{array}{c}0.028 * * * \\
(0.005)\end{array}$ & $\begin{array}{c}0.454^{* *} \\
(0.177)\end{array}$ & $\begin{array}{c}-0.018^{* *} \\
(0.008)\end{array}$ \\
\hline Age & $\begin{array}{c}0.045^{* * *} \\
(0.005)\end{array}$ & $\begin{array}{c}2.458 * * * \\
(0.196)\end{array}$ & $\begin{array}{c}0.034^{* * *} \\
(0.002)\end{array}$ & $\begin{array}{c}1.032^{* * *} \\
(0.104)\end{array}$ & $\begin{array}{c}0.031^{* * *} \\
(0.002)\end{array}$ & $\begin{array}{c}0.774^{* * *} \\
(0.087)\end{array}$ & $\begin{array}{c}0.040^{* * *} \\
(0.005)\end{array}$ & $\begin{array}{c}1.074 * * * \\
(0.107)\end{array}$ & $\begin{array}{c}0.040^{* * *} \\
(0.003)\end{array}$ \\
\hline Male & $\begin{array}{c}-0.078 * * * \\
(0.017)\end{array}$ & $\begin{array}{l}-0.565 \\
(0.402)\end{array}$ & $\begin{array}{c}0.036 * * * \\
(0.010)\end{array}$ & $\begin{array}{c}1.402 * * * \\
(0.347)\end{array}$ & $\begin{array}{c}0.035^{* * *} \\
(0.012)\end{array}$ & $\begin{array}{c}1.078 * * * \\
(0.339)\end{array}$ & $\begin{array}{c}-0.125^{* * *} \\
(0.024)\end{array}$ & $\begin{array}{c}-2.802 * * * \\
(0.445)\end{array}$ & $\begin{array}{l}0.015^{* *} \\
(0.007)\end{array}$ \\
\hline Ever in school & $\begin{array}{c}0.059 * * * \\
(0.011)\end{array}$ & $\begin{array}{c}-2.339 * * * \\
(0.784)\end{array}$ & $\begin{array}{c}0.000 \\
(0.010)\end{array}$ & $\begin{array}{c}-1.602 * * * \\
(0.397)\end{array}$ & $\begin{array}{l}-0.003 \\
(0.009)\end{array}$ & $\begin{array}{c}-1.249 * * * \\
(0.383)\end{array}$ & $\begin{array}{c}0.068 * * * \\
(0.010)\end{array}$ & $\begin{array}{l}-0.691 * \\
(0.370)\end{array}$ & $\begin{array}{c}0.618^{* * *} \\
(0.017)\end{array}$ \\
\hline HhH male & $\begin{array}{l}0.010 * \\
(0.005)\end{array}$ & $\begin{array}{c}0.735^{* * * *} \\
(0.222)\end{array}$ & $\begin{array}{l}0.011^{*} \\
(0.006)\end{array}$ & $\begin{array}{l}0.312 * * \\
(0.117)\end{array}$ & $\begin{array}{c}0.017 * * * \\
(0.006)\end{array}$ & $\begin{array}{l}0.295 * * \\
(0.120)\end{array}$ & $\begin{array}{l}0.013 * * \\
(0.006)\end{array}$ & $\begin{array}{l}0.262 * \\
(0.155)\end{array}$ & $\begin{array}{l}-0.000 \\
(0.004)\end{array}$ \\
\hline $\begin{array}{l}\text { Mother lives at } \\
\text { home }\end{array}$ & $\begin{array}{c}-0.011 * * * \\
(0.004)\end{array}$ & $\begin{array}{l}-0.459 * \\
(0.260)\end{array}$ & $\begin{array}{l}-0.001 \\
(0.006)\end{array}$ & $\begin{array}{l}-0.137 \\
(0.162)\end{array}$ & $\begin{array}{c}0.006 \\
(0.005)\end{array}$ & $\begin{array}{c}0.069 \\
(0.121)\end{array}$ & $\begin{array}{l}-0.005 \\
(0.004)\end{array}$ & $\begin{array}{c}-0.451^{* *} \\
(0.178)\end{array}$ & $\begin{array}{c}0.029 * * * \\
(0.006)\end{array}$ \\
\hline $\begin{array}{l}\text { Father lives at } \\
\text { home }\end{array}$ & $\begin{array}{l}-0.006 \\
(0.004)\end{array}$ & $\begin{array}{c}0.314 \\
(0.423)\end{array}$ & $\begin{array}{c}0.001 \\
(0.007)\end{array}$ & $\begin{array}{l}0.318^{*} \\
(0.181)\end{array}$ & $\begin{array}{c}0.006 \\
(0.006)\end{array}$ & $\begin{array}{l}0.389 * * \\
(0.159)\end{array}$ & $\begin{array}{c}-0.009 * * \\
(0.004)\end{array}$ & $\begin{array}{l}-0.115 \\
(0.200)\end{array}$ & $\begin{array}{l}0.010 * \\
(0.005)\end{array}$ \\
\hline $\begin{array}{l}\text { N. of siblings aged } \\
5-15\end{array}$ & $\begin{array}{l}-0.001 \\
(0.001)\end{array}$ & $\begin{array}{c}0.122 \\
(0.102)\end{array}$ & $\begin{array}{l}0.003 * \\
(0.002)\end{array}$ & $\begin{array}{c}0.081 \\
(0.070)\end{array}$ & $\begin{array}{l}0.003^{*} \\
(0.002)\end{array}$ & $\begin{array}{c}0.057 \\
(0.059)\end{array}$ & $\begin{array}{l}-0.001 \\
(0.001)\end{array}$ & $\begin{array}{c}0.021 \\
(0.023)\end{array}$ & $\begin{array}{c}0.003 \\
(0.002)\end{array}$ \\
\hline $\begin{array}{l}\text { N. of children }<5 \\
\text { y.o. at home }\end{array}$ & $\begin{array}{l}0.004^{* *} \\
(0.001)\end{array}$ & $\begin{array}{l}0.163^{*} \\
(0.094)\end{array}$ & $\begin{array}{l}0.002 * \\
(0.001)\end{array}$ & $\begin{array}{c}0.030 \\
(0.051)\end{array}$ & $\begin{array}{c}0.000 \\
(0.001)\end{array}$ & $\begin{array}{l}-0.004 \\
(0.057)\end{array}$ & $\begin{array}{l}0.004 * * \\
(0.002)\end{array}$ & $\begin{array}{c}0.145^{* * *} \\
(0.049)\end{array}$ & $\begin{array}{c}-0.007 * * * \\
(0.003)\end{array}$ \\
\hline $\begin{array}{l}\text { N. of female } \\
\text { adults at home }\end{array}$ & $\begin{array}{c}-0.010 * * * \\
(0.003)\end{array}$ & $\begin{array}{c}-0.346^{* * *} \\
(0.104)\end{array}$ & $\begin{array}{l}-0.001 \\
(0.003)\end{array}$ & $\begin{array}{l}-0.098 \\
(0.074)\end{array}$ & $\begin{array}{l}-0.002 \\
(0.002)\end{array}$ & $\begin{array}{l}-0.114^{*} \\
(0.058)\end{array}$ & $\begin{array}{c}-0.008 * * * \\
(0.003)\end{array}$ & $\begin{array}{c}-0.255^{* * *} \\
(0.059)\end{array}$ & $\begin{array}{c}0.000 \\
(0.001)\end{array}$ \\
\hline Household size & $\begin{array}{c}0.002 \\
(0.001)\end{array}$ & $\begin{array}{l}0.203 * * \\
(0.093)\end{array}$ & $\begin{array}{c}0.002 \\
(0.002)\end{array}$ & $\begin{array}{l}0.099 * \\
(0.058)\end{array}$ & $\begin{array}{c}0.002 \\
(0.002)\end{array}$ & $\begin{array}{l}0.111 * * \\
(0.044)\end{array}$ & $\begin{array}{c}0.000 \\
(0.001)\end{array}$ & $\begin{array}{c}0.050 \\
(0.035)\end{array}$ & $\begin{array}{l}-0.001 \\
(0.001)\end{array}$ \\
\hline Birth & $\begin{array}{l}-0.004 \\
(0.004)\end{array}$ & $\begin{array}{c}-0.676^{* * *} \\
(0.210)\end{array}$ & $\begin{array}{c}-0.008^{* * *} \\
(0.003)\end{array}$ & $\begin{array}{c}-0.291^{* *} \\
(0.113)\end{array}$ & $\begin{array}{c}-0.006^{* *} \\
(0.003)\end{array}$ & $\begin{array}{c}-0.210^{* *} \\
(0.092)\end{array}$ & $\begin{array}{l}-0.004 \\
(0.003)\end{array}$ & $\begin{array}{c}-0.317^{* * *} \\
(0.081)\end{array}$ & $\begin{array}{c}0.001 \\
(0.004)\end{array}$ \\
\hline Urban area & $\begin{array}{c}-0.052^{* * *} \\
(0.007)\end{array}$ & $\begin{array}{c}-5.476 * * * \\
(0.675)\end{array}$ & $\begin{array}{c}-0.124^{* * *} \\
(0.015)\end{array}$ & $\begin{array}{c}-2.651^{* * *} \\
(0.434)\end{array}$ & $\begin{array}{c}-0.134^{* * *} \\
(0.017)\end{array}$ & $\begin{array}{c}-2.562 * * * \\
(0.407)\end{array}$ & $\begin{array}{c}-0.032 * * * \\
(0.005)\end{array}$ & $\begin{array}{c}-1.175^{* * *} \\
(0.136)\end{array}$ & $\begin{array}{c}0.035^{* * *} \\
(0.007)\end{array}$ \\
\hline 1st quantile & $\begin{array}{c}0.075^{* * *} \\
(0.011)\end{array}$ & $\begin{array}{c}6.431^{* * *} \\
(0.659)\end{array}$ & $\begin{array}{c}0.133^{* * *} \\
(0.017)\end{array}$ & $\begin{array}{c}3.397 * * * \\
(0.483)\end{array}$ & $\begin{array}{c}0.140 * * * \\
(0.019)\end{array}$ & $\begin{array}{c}2.804^{* * *} \\
(0.395)\end{array}$ & $\begin{array}{c}0.045^{* * *} \\
(0.010)\end{array}$ & $\begin{array}{c}1.487 * * * \\
(0.285)\end{array}$ & $\begin{array}{c}-0.113 * * * \\
(0.014)\end{array}$ \\
\hline 2nd quantile & $\begin{array}{c}0.053 * * * \\
(0.009)\end{array}$ & $\begin{array}{c}4.943^{* * *} \\
(0.787)\end{array}$ & $\begin{array}{c}0.102^{* * *} \\
(0.018)\end{array}$ & $\begin{array}{c}2.610 * * * \\
(0.508)\end{array}$ & $\begin{array}{c}0.109 * * * \\
(0.020)\end{array}$ & $\begin{array}{c}2.048 * * * \\
(0.432)\end{array}$ & $\begin{array}{c}0.037 * * * \\
(0.011)\end{array}$ & $\begin{array}{c}1.033 * * * \\
(0.263)\end{array}$ & $\begin{array}{c}-0.085 * * * \\
(0.015)\end{array}$ \\
\hline 3rd quantile & $\begin{array}{c}0.045^{* * *} \\
(0.009)\end{array}$ & $\begin{array}{c}3.977^{* * * *} \\
(0.836)\end{array}$ & $\begin{array}{c}0.089 * * * \\
(0.019)\end{array}$ & $\begin{array}{c}2.002 * * * \\
(0.475)\end{array}$ & $\begin{array}{c}0.089 * * * \\
(0.020)\end{array}$ & $\begin{array}{c}1.486 * * * \\
(0.411)\end{array}$ & $\begin{array}{c}0.031^{* * *} \\
(0.009)\end{array}$ & $\begin{array}{c}0.868 * * * \\
(0.243)\end{array}$ & $\begin{array}{c}-0.056 * * * \\
(0.010)\end{array}$ \\
\hline 4th quantile & $\begin{array}{c}0.022 * * * \\
(0.008)\end{array}$ & $\begin{array}{c}2.432 * * * \\
(0.720)\end{array}$ & $\begin{array}{c}0.048 * * * \\
(0.014)\end{array}$ & $\begin{array}{c}1.216^{* * *} \\
(0.415)\end{array}$ & $\begin{array}{c}0.053^{* * *} \\
(0.015)\end{array}$ & $\begin{array}{l}0.897 * * \\
(0.369)\end{array}$ & $\begin{array}{l}0.017 * * \\
(0.007)\end{array}$ & $\begin{array}{l}0.562 * * \\
(0.250)\end{array}$ & $\begin{array}{c}-0.036 * * * \\
(0.006)\end{array}$ \\
\hline Constant & $\begin{array}{c}0.294 * * * \\
(0.045)\end{array}$ & $\begin{array}{c}-6.775^{* * *} \\
(1.641)\end{array}$ & $\begin{array}{c}-0.062 * * * \\
(0.022)\end{array}$ & $\begin{array}{c}-5.012 * * * \\
(1.097)\end{array}$ & $\begin{array}{c}-0.112^{* * *} \\
(0.026)\end{array}$ & $\begin{array}{c}-3.911^{* * *} \\
(0.868)\end{array}$ & $\begin{array}{c}0.325^{* * *} \\
(0.045)\end{array}$ & $\begin{array}{c}0.297 \\
(0.806)\end{array}$ & $\begin{array}{c}-0.193 * * * \\
(0.031)\end{array}$ \\
\hline Observations & 247,975 & 246,738 & 249,594 & 249,348 & 247,992 & 247,974 & 248,451 & 248,214 & 168,841 \\
\hline R-squared & 0.258 & 0.244 & 0.239 & 0.131 & 0.215 & 0.113 & 0.241 & 0.177 & 0.218 \\
\hline
\end{tabular}

Robust standard errors are reported in parentheses, clustered at the country level. ${ }^{* * *} \mathrm{p}<0.01,{ }^{* *} \mathrm{p}<0.05, * \mathrm{p}<0.1$

Notes: Dependent variables are dichotomous indicators as well as continuous variables (i.e. hours) for work supply in the last week. School attendance is a dichotomous variable referred to the last year. The sample includes children aged 5-14 in 38 countries. The table reports linear probability model results. Reference categories for reported dummy variables are 'higher education (i.e. more than primary)', 'female', 'female household's head', 'rural area'. Other controls include dummies for missing information on household head's education, wealth index, rural/urban area and country fixed effects. 
Table 16 - Net migration flows and child labor (largest sample)

(1) (2) (3) (4)

Any work Total hours Market Hours in of work work market
(5)

Family

business
(6)

Hours in

family business
(7)

Chores
(8)

Hours in School chores attendance

\begin{tabular}{|c|c|c|c|c|c|c|c|c|c|}
\hline $\begin{array}{l}\text { Net Mig } \\
\text { flow*HhH low }\end{array}$ & $\begin{array}{c}-0.115^{* *} \\
(0.053)\end{array}$ & $\begin{array}{l}-8.008 \\
(4.826)\end{array}$ & $\begin{array}{l}-0.101 \\
(0.088)\end{array}$ & $\begin{array}{l}-2.857 \\
(2.844)\end{array}$ & $\begin{array}{l}-0.111 \\
(0.103)\end{array}$ & $\begin{array}{l}-1.939 \\
(2.301)\end{array}$ & $\begin{array}{c}-0.127^{* *} \\
(0.052)\end{array}$ & $\begin{array}{c}-3.755^{* *} \\
(1.805)\end{array}$ & $\begin{array}{l}0.106 * * \\
(0.048)\end{array}$ \\
\hline HhH low-skilled & $\begin{array}{c}0.020 * * * \\
(0.006)\end{array}$ & $\begin{array}{l}0.986^{*} \\
(0.507)\end{array}$ & $\begin{array}{c}0.018^{* *} \\
(0.009)\end{array}$ & $\begin{array}{c}0.384 \\
(0.351)\end{array}$ & $\begin{array}{c}0.020^{* *} \\
(0.009)\end{array}$ & $\begin{array}{c}0.161 \\
(0.284)\end{array}$ & $\begin{array}{c}0.021^{* * *} \\
(0.004)\end{array}$ & $\begin{array}{c}0.478 * * * \\
(0.156)\end{array}$ & $\begin{array}{c}-0.031^{* * *} \\
(0.007)\end{array}$ \\
\hline Age & $\begin{array}{c}0.045^{* * *} \\
(0.005)\end{array}$ & $\begin{array}{c}2.434^{* * * *} \\
(0.195)\end{array}$ & $\begin{array}{c}0.033^{* * *} \\
(0.002)\end{array}$ & $\begin{array}{c}1.020^{* * *} \\
(0.104)\end{array}$ & $\begin{array}{c}0.030 * * * \\
(0.002)\end{array}$ & $\begin{array}{c}0.764^{* * *} \\
(0.087)\end{array}$ & $\begin{array}{c}0.040 * * * \\
(0.005)\end{array}$ & $\begin{array}{c}1.067^{* * * *} \\
(0.106)\end{array}$ & $\begin{array}{c}0.040^{* * *} \\
(0.003)\end{array}$ \\
\hline Male & $\begin{array}{c}-0.078 * * * \\
(0.017)\end{array}$ & $\begin{array}{l}-0.581 \\
(0.405)\end{array}$ & $\begin{array}{c}0.035 * * * \\
(0.010)\end{array}$ & $\begin{array}{c}1.394 * * * \\
(0.348)\end{array}$ & $\begin{array}{c}0.035 * * * \\
(0.012)\end{array}$ & $\begin{array}{c}1.072 * * * \\
(0.339)\end{array}$ & $\begin{array}{c}-0.125^{* * *} \\
(0.024)\end{array}$ & $\begin{array}{c}-2.807 * * * \\
(0.446)\end{array}$ & $\begin{array}{l}0.016 * * \\
(0.007)\end{array}$ \\
\hline Ever in school & $\begin{array}{c}0.060 * * * \\
(0.010)\end{array}$ & $\begin{array}{c}-2.007^{* *} \\
(0.747)\end{array}$ & $\begin{array}{c}0.003 \\
(0.009)\end{array}$ & $\begin{array}{c}-1.435^{* * *} \\
(0.385)\end{array}$ & $\begin{array}{c}0.001 \\
(0.008)\end{array}$ & $\begin{array}{c}-1.112^{* * *} \\
(0.365)\end{array}$ & *** & $\begin{array}{l}-0.605^{*} \\
(0.355)\end{array}$ & $\begin{array}{c}0.614 * * * \\
(0.018)\end{array}$ \\
\hline HhH male & $\begin{array}{l}0.010^{*} \\
(0.005)\end{array}$ & $\begin{array}{c}0.981^{* * *} \\
(0.245)\end{array}$ & $\begin{array}{l}0.014 * * \\
(0.006)\end{array}$ & $\begin{array}{c}0.434^{* * *} \\
(0.125)\end{array}$ & $\begin{array}{c}0.021 * * * \\
(0.007)\end{array}$ & $\begin{array}{c}0.396 * * * \\
(0.129)\end{array}$ & $\begin{array}{l}0.0 \\
(0.0\end{array}$ & $\begin{array}{l}0.327^{* *} \\
(0.158)\end{array}$ & $\begin{array}{l}-0.006 \\
(0.004)\end{array}$ \\
\hline Mother lives at $\mathrm{h}$ & $\begin{array}{c}-0.011^{* * *} \\
(0.004)\end{array}$ & $\begin{array}{l}-0.425 \\
(0.263)\end{array}$ & $\begin{array}{l}-0.000 \\
(0.006)\end{array}$ & $\begin{array}{l}-0.119 \\
(0.162)\end{array}$ & $\begin{array}{r}0.0 \\
(0.0\end{array}$ & $\begin{array}{c}0.084 \\
(0.122)\end{array}$ & $\begin{array}{l}-0.005 \\
(0.004)\end{array}$ & $\begin{array}{c}-0.441^{* *} \\
(0.179)\end{array}$ & $\begin{array}{c}0.028 * * * \\
(0.006)\end{array}$ \\
\hline Father lives at ho & $\begin{array}{l}-0.006 \\
(0.004)\end{array}$ & $\begin{array}{c}0.271 \\
(0.420)\end{array}$ & $\begin{array}{c}0.001 \\
(0.007)\end{array}$ & $\begin{array}{c}0.296 \\
(0.178)\end{array}$ & & $\begin{array}{l}0.371 * * \\
(0.156)\end{array}$ & $\begin{array}{l}-0.0 \\
(0 .\end{array}$ & $\begin{array}{l}-0.126 \\
(0.200)\end{array}$ & $\begin{array}{l}0.010 * * \\
(0.005)\end{array}$ \\
\hline $\begin{array}{l}\text { N. of siblings } \\
\text { aged 5-15 }\end{array}$ & $\begin{array}{l}-0.001 \\
(0.001)\end{array}$ & $\begin{array}{c}0.151 \\
(0.095)\end{array}$ & $\begin{array}{l}0.003^{*} \\
(0.002)\end{array}$ & $\begin{array}{c}0.096 \\
(0.066)\end{array}$ & $\begin{array}{l}0.00 \\
(0.0\end{array}$ & $\begin{array}{c}0.069 \\
(0.056)\end{array}$ & & $\begin{array}{c}0.029 \\
(0.025)\end{array}$ & $\begin{array}{c}0.003 \\
(0.002)\end{array}$ \\
\hline $\begin{array}{l}\text { N. of children } \\
<5 \text { y.o. at home }\end{array}$ & $\begin{array}{l}0.004^{* *} \\
(0.001)\end{array}$ & $\begin{array}{l}0.199 * * \\
(0.094)\end{array}$ & $\begin{array}{l}0.002^{*} \\
(0.001)\end{array}$ & $\begin{array}{c}0.047 \\
(0.050)\end{array}$ & $\begin{array}{l}0.0 \\
(0 . C\end{array}$ & $\begin{array}{c}0.011 \\
(0.057)\end{array}$ & $\begin{array}{l}0.0 \\
(0\end{array}$ & $\begin{array}{c}0.154^{* * *} \\
(0.048)\end{array}$ & $\begin{array}{c}-0.008^{* * *} \\
(0.003)\end{array}$ \\
\hline $\begin{array}{l}\text { N. of female } \\
\text { adults at home }\end{array}$ & $\begin{array}{c}-0.010 * * * \\
(0.002)\end{array}$ & $\begin{array}{c}-0.311^{* * *} \\
(0.100)\end{array}$ & $\begin{array}{l}-0.001 \\
(0.003)\end{array}$ & $\begin{array}{l}-0.081 \\
(0.070)\end{array}$ & $\begin{array}{l}-0 . \\
(0 .\end{array}$ & $\begin{array}{l}-0.100 * \\
(0.056)\end{array}$ & $\begin{array}{c}-0.008 * * * \\
(0.003)\end{array}$ & $\begin{array}{c}-0.246 * * * \\
(0.059)\end{array}$ & $\begin{array}{l}-0.000 \\
(0.001)\end{array}$ \\
\hline Hous & $\begin{array}{c}0.002 \\
(0.001)\end{array}$ & $\begin{array}{l}0.175 * \\
(0.091)\end{array}$ & $\begin{array}{c}0.002 \\
(0.002)\end{array}$ & $\begin{array}{c}0.085 \\
(0.056)\end{array}$ & $\begin{array}{r}0 . \\
(0 .\end{array}$ & $\begin{array}{l}0.099 * * \\
(0.043)\end{array}$ & 0 & $\begin{array}{c}0.043 \\
(0.035)\end{array}$ & $\begin{array}{c}0.000 \\
(0.001)\end{array}$ \\
\hline Birth & $\begin{array}{l}-0.004 \\
(0.004)\end{array}$ & $\begin{array}{c}-0.681^{* * *} \\
(0.207)\end{array}$ & $\begin{array}{c}-0.008 * * * \\
(0.003)\end{array}$ & $\begin{array}{c}-0.294^{* *} \\
(0.111)\end{array}$ & $\begin{array}{c}-0.006 * * \\
(0.003)\end{array}$ & $\begin{array}{c}-0.212^{* *} \\
(0.091)\end{array}$ & $\begin{array}{l}-0.004 \\
(0.003)\end{array}$ & $\begin{array}{c}-0.319 * * * \\
(0.081)\end{array}$ & $\begin{array}{c}0.001 \\
(0.004)\end{array}$ \\
\hline Urbai & $\begin{array}{c}-0.051^{* * *} \\
(0.006)\end{array}$ & $\begin{array}{c}-5.355^{* * *} \\
(0.665)\end{array}$ & $\begin{array}{c}-0.123^{* * *} \\
(0.015)\end{array}$ & $\begin{array}{c}-2.591^{* * *} \\
(0.432)\end{array}$ & $\begin{array}{c}-0.132^{* * *} \\
(0.017)\end{array}$ & $\begin{array}{c}-2.513^{* * *} \\
(0.404)\end{array}$ & $\begin{array}{c}-0.032 * * * \\
(0.005)\end{array}$ & $\begin{array}{c}-1.144^{* * *} \\
(0.137)\end{array}$ & $\begin{array}{c}0.032 * * * \\
(0.007)\end{array}$ \\
\hline \multicolumn{10}{|l|}{ Wealth index } \\
\hline 1st c & $\begin{array}{c}0.074^{* * *} \\
(0.011)\end{array}$ & $\begin{array}{c}5.990 * * * \\
(0.617)\end{array}$ & $\begin{array}{c}0.129 * * * \\
(0.016)\end{array}$ & $\begin{array}{c}3.174 * * * \\
(0.465)\end{array}$ & $\begin{array}{c}0.134^{* * *} \\
(0.018)\end{array}$ & $\begin{array}{c}2.621^{* * *} \\
(0.385)\end{array}$ & $\begin{array}{c}0.046^{* * *} \\
(0.010)\end{array}$ & $\begin{array}{c}1.373^{* * *} \\
(0.290)\end{array}$ & $\begin{array}{c}-0.103 * * * \\
(0.013)\end{array}$ \\
\hline 2nd quantile & $\begin{array}{c}0.053^{* * *} \\
(0.009)\end{array}$ & $\begin{array}{c}4.592^{* * * *} \\
(0.780)\end{array}$ & $\begin{array}{c}0.099 * * * \\
(0.018)\end{array}$ & $\begin{array}{c}2.432 * * * \\
(0.509)\end{array}$ & $\begin{array}{c}0.104^{* * *} \\
(0.019)\end{array}$ & $\begin{array}{c}1.903^{* * *} \\
(0.437)\end{array}$ & $\begin{array}{c}0.038 * * * \\
(0.011)\end{array}$ & $\begin{array}{c}0.942^{* * *} \\
(0.266)\end{array}$ & $\begin{array}{c}-0.077 * * * \\
(0.014)\end{array}$ \\
\hline 3rd quantile & $\begin{array}{c}0.045^{* * *} \\
(0.009)\end{array}$ & $\begin{array}{c}3.705^{* * *} \\
(0.830)\end{array}$ & $\begin{array}{c}0.086^{* * *} \\
(0.019)\end{array}$ & $\begin{array}{c}1.863 * * * \\
(0.475)\end{array}$ & $\begin{array}{c}0.085 * * * \\
(0.020)\end{array}$ & $\begin{array}{c}1.374^{* * *} \\
(0.413)\end{array}$ & $\begin{array}{c}0.032 * * * \\
(0.009)\end{array}$ & $\begin{array}{c}0.799 * * * \\
(0.242)\end{array}$ & $\begin{array}{c}-0.050 * * * \\
(0.009)\end{array}$ \\
\hline 4th quantile & $\begin{array}{c}0.022^{* * *} \\
(0.008)\end{array}$ & $\begin{array}{c}2.256^{* * *} \\
(0.716)\end{array}$ & $\begin{array}{c}0.047 * * * \\
(0.014)\end{array}$ & $\begin{array}{l}1.127 * * \\
(0.416)\end{array}$ & $\begin{array}{c}0.050 * * * \\
(0.015)\end{array}$ & $\begin{array}{l}0.825 * * \\
(0.372)\end{array}$ & $\begin{array}{c}0.017 * * \\
(0.007)\end{array}$ & $\begin{array}{c}0.516 * * \\
(0.250)\end{array}$ & $\begin{array}{c}-0.032^{* * *} \\
(0.006)\end{array}$ \\
\hline Constant & $\begin{array}{c}0.292^{* * *} \\
(0.046)\end{array}$ & $\begin{array}{c}-7.723^{* * *} \\
(1.717)\end{array}$ & $\begin{array}{c}-0.071^{* * *} \\
(0.023)\end{array}$ & $\begin{array}{c}-5.483^{* * *} \\
(1.126)\end{array}$ & $\begin{array}{c}-0.125^{* * *} \\
(0.027)\end{array}$ & $\begin{array}{c}-4.299 * * * \\
(0.881)\end{array}$ & $\begin{array}{c}0.327^{* * *} \\
(0.046)\end{array}$ & $\begin{array}{c}0.045 \\
(0.839)\end{array}$ & $\begin{array}{c}-0.176 * * * \\
(0.031)\end{array}$ \\
\hline UDe & 247,975 & 246,738 & 249,594 & 249,348 & 247,992 & 247,974 & 248,451 & 248,214 & 168,841 \\
\hline R-squared & 0.258 & 0.244 & 0.239 & 0.132 & 0.216 & 0.113 & 0.241 & 0.177 & 0.219 \\
\hline
\end{tabular}

Robust standard errors are reported in parentheses, clustered at the country level. ${ }^{* * *} \mathrm{p}<0.01,{ }^{* *} \mathrm{p}<0.05,{ }^{*} \mathrm{p}<0.1$

Notes: Dependent variables are dichotomous indicators as well as continuous variables (i.e. hours) for work supply in the last week. School attendance is a dichotomous variable referred to the last year. The sample includes children aged 5-14 in 38 countries. The table reports linear probability model results. Reference categories for reported dummy variables are 'higher education (i.e. more than primary)', 'female', 'female household's head', 'rural area'. Other controls include dummies for missing information on household head's education, wealth index, rural/urban area and country fixed effects. 
Table 17 - Skill composition of net migration flows and child labor (largest sample)

\begin{tabular}{|c|c|c|c|c|c|c|c|c|c|}
\hline Any work & $\begin{array}{c}\text { (2) } \\
\text { Total hours } \\
\text { of work }\end{array}$ & $\begin{array}{c}\text { (3) } \\
\text { Market } \\
\text { work }\end{array}$ & $\begin{array}{c}\text { (4) } \\
\text { Hours in } \\
\text { market } \\
\text { work } \\
\end{array}$ & $\begin{array}{c}\text { (5) } \\
\text { Family } \\
\text { business }\end{array}$ & $\begin{array}{c}\text { (6) } \\
\text { Hours in } \\
\text { family } \\
\text { business } \\
\end{array}$ & Chores & $\begin{array}{c}\text { (8) } \\
\text { Hours in } \\
\text { chores }\end{array}$ & $\begin{array}{c}\text { (9) } \\
\text { School } \\
\text { attendance }\end{array}$ & SCHlastY \\
\hline $\begin{array}{l}\text { Net mig flow low } \\
\text { skilled*HhH low sk }\end{array}$ & $\begin{array}{c}-0.192 * * \\
(0.082)\end{array}$ & $\begin{array}{c}-14.043^{*} \\
(8.233)\end{array}$ & $\begin{array}{l}-0.168 \\
(0.142)\end{array}$ & $\begin{array}{l}-4.129 \\
(4.799)\end{array}$ & $\begin{array}{l}-0.188 \\
(0.170)\end{array}$ & $\begin{array}{l}-2.994 \\
(4.083)\end{array}$ & $\begin{array}{c}-0.208^{* *} \\
(0.081)\end{array}$ & $\begin{array}{c}-6.861^{* *} \\
(3.267)\end{array}$ & $\begin{array}{c}0.136 \\
(0.108)\end{array}$ \\
\hline HhH low-skilled & $\begin{array}{c}0.019 * * * \\
(0.006)\end{array}$ & $\begin{array}{l}0.980 * \\
(0.501)\end{array}$ & $\begin{array}{l}0.018 * * \\
(0.008)\end{array}$ & $\begin{array}{c}0.372 \\
(0.348)\end{array}$ & $\begin{array}{l}0.020 * * \\
(0.009)\end{array}$ & $\begin{array}{c}0.155 \\
(0.281)\end{array}$ & $\begin{array}{c}0.021^{* * *} \\
(0.004)\end{array}$ & $\begin{array}{c}0.478^{* * *} \\
(0.154)\end{array}$ & $\begin{array}{c}-0.030 * * * \\
(0.007)\end{array}$ \\
\hline Age & $\begin{array}{c}0.045^{* * *} \\
(0.005)\end{array}$ & $\begin{array}{c}2.433^{* * *} \\
(0.195)\end{array}$ & $\begin{array}{c}0.033^{* * *} \\
(0.002)\end{array}$ & $\begin{array}{c}1.020 * * * \\
(0.104)\end{array}$ & $\begin{array}{c}0.030 * * * \\
(0.002)\end{array}$ & $\begin{array}{c}0.764^{* * *} \\
(0.087)\end{array}$ & $\begin{array}{c}0.040 * * * \\
(0.005)\end{array}$ & $\begin{array}{c}1.067^{* * *} \\
(0.106)\end{array}$ & $\begin{array}{c}0.040 * * * \\
(0.003)\end{array}$ \\
\hline Male & $\begin{array}{c}-0.078 * * * \\
(0.017)\end{array}$ & $\begin{array}{l}-0.581 \\
(0.405)\end{array}$ & $\begin{array}{c}0.035^{* * *} \\
(0.010)\end{array}$ & $\begin{array}{c}1.394 * * * \\
(0.348)\end{array}$ & $\begin{array}{c}0.035^{* * *} \\
(0.012)\end{array}$ & $\begin{array}{c}1.072 * * * \\
(0.339)\end{array}$ & $\begin{array}{c}-0.125 * * * \\
(0.024)\end{array}$ & $\begin{array}{c}-2.807 * * * \\
(0.446)\end{array}$ & $\begin{array}{l}0.016 * * \\
(0.007)\end{array}$ \\
\hline Ever in school & $\begin{array}{c}0.060 * * * \\
(0.010)\end{array}$ & $\begin{array}{c}-2.007 * * \\
(0.747)\end{array}$ & $\begin{array}{c}0.003 \\
(0.009)\end{array}$ & $\begin{array}{c}-1.435 * * * \\
(0.385)\end{array}$ & $\begin{array}{c}0.001 \\
(0.008)\end{array}$ & $\begin{array}{c}-1.112 * * * \\
(0.365)\end{array}$ & $\begin{array}{c}0.067 * * * \\
(0.010)\end{array}$ & $\begin{array}{l}-0.605 * \\
(0.355)\end{array}$ & $\begin{array}{c}0.614 * * * \\
(0.018)\end{array}$ \\
\hline HhH male & $\begin{array}{l}0.010^{*} \\
(0.005)\end{array}$ & $\begin{array}{c}0.982 * * * \\
(0.245)\end{array}$ & $\begin{array}{l}0.014^{* *} \\
(0.006)\end{array}$ & $\begin{array}{c}0.434^{* * *} \\
(0.125)\end{array}$ & $\begin{array}{c}0.021^{* * *} \\
(0.007)\end{array}$ & $\begin{array}{c}0.396 * * * \\
(0.129)\end{array}$ & $\begin{array}{l}0.012 * \\
(0.006)\end{array}$ & $\begin{array}{l}0.328 * * \\
(0.158)\end{array}$ & $\begin{array}{l}-0.006 \\
(0.004)\end{array}$ \\
\hline $\begin{array}{l}\text { Mother lives at } \\
\text { home }\end{array}$ & $\begin{array}{c}-0.011^{* * *} \\
(0.004)\end{array}$ & $\begin{array}{l}-0.425 \\
(0.263)\end{array}$ & $\begin{array}{l}-0.000 \\
(0.006)\end{array}$ & $\begin{array}{l}-0.119 \\
(0.162)\end{array}$ & $\begin{array}{c}0.007 \\
(0.005)\end{array}$ & $\begin{array}{c}0.084 \\
(0.122)\end{array}$ & $\begin{array}{l}-0.005 \\
(0.004)\end{array}$ & $\begin{array}{c}-0.441^{* *} \\
(0.179)\end{array}$ & $\begin{array}{c}0.028 * * * \\
(0.006)\end{array}$ \\
\hline Father lives at home & $\begin{array}{c}-0.006 \\
(0.004)\end{array}$ & $\begin{array}{c}0.271 \\
(0.420)\end{array}$ & $\begin{array}{c}0.001 \\
(0.007)\end{array}$ & $\begin{array}{c}0.296 \\
(0.178)\end{array}$ & $\begin{array}{c}0.005 \\
(0.006)\end{array}$ & $\begin{array}{c}0.371^{* *} \\
(0.156)\end{array}$ & $\begin{array}{c}-0.009 * * \\
(0.004)\end{array}$ & $\begin{array}{c}-0.126 \\
(0.200)\end{array}$ & $\begin{array}{c}0.010^{* *} \\
(0.005)\end{array}$ \\
\hline $\begin{array}{l}\text { N. of siblings aged 5- } \\
15\end{array}$ & $\begin{array}{l}-0.001 \\
(0.001)\end{array}$ & $\begin{array}{c}0.151 \\
(0.095)\end{array}$ & $\begin{array}{l}0.003 * \\
(0.002)\end{array}$ & $\begin{array}{c}0.096 \\
(0.066)\end{array}$ & $\begin{array}{l}0.003^{* *} \\
(0.002)\end{array}$ & $\begin{array}{c}0.069 \\
(0.056)\end{array}$ & $\begin{array}{l}-0.001 \\
(0.001)\end{array}$ & $\begin{array}{c}0.029 \\
(0.025)\end{array}$ & $\begin{array}{c}0.003 \\
(0.002)\end{array}$ \\
\hline $\begin{array}{l}\text { N. of children }<5 \\
\text { y.o. at home }\end{array}$ & $\begin{array}{l}0.004^{* *} \\
(0.001)\end{array}$ & $\begin{array}{l}0.199 * * \\
(0.094)\end{array}$ & $\begin{array}{l}0.002 * \\
(0.001)\end{array}$ & $\begin{array}{c}0.048 \\
(0.050)\end{array}$ & $\begin{array}{c}0.001 \\
(0.001)\end{array}$ & $\begin{array}{c}0.011 \\
(0.057)\end{array}$ & $\begin{array}{l}0.004^{* *} \\
(0.002)\end{array}$ & $\begin{array}{c}0.154^{* * *} \\
(0.048)\end{array}$ & $\begin{array}{c}-0.008^{* * *} \\
(0.003)\end{array}$ \\
\hline $\begin{array}{l}\text { N. of female adults } \\
\text { at home }\end{array}$ & $\begin{array}{c}-0.010 * * * \\
(0.002)\end{array}$ & $\begin{array}{c}-0.311^{* * *} \\
(0.100)\end{array}$ & $\begin{array}{c}-0.001 \\
(0.003)\end{array}$ & $\begin{array}{c}-0.081 \\
(0.070)\end{array}$ & $\begin{array}{c}-0.001 \\
(0.002)\end{array}$ & $\begin{array}{l}-0.100 * \\
(0.055)\end{array}$ & $\begin{array}{c}-0.008^{* * *} \\
(0.003)\end{array}$ & $\begin{array}{c}-0.246^{* * *} \\
(0.059)\end{array}$ & $\begin{array}{c}-0.000 \\
(0.001)\end{array}$ \\
\hline Household size & $\begin{array}{c}0.002 \\
(0.001)\end{array}$ & $\begin{array}{l}0.175^{*} \\
(0.091)\end{array}$ & $\begin{array}{c}0.002 \\
(0.002)\end{array}$ & $\begin{array}{c}0.085 \\
(0.056)\end{array}$ & $\begin{array}{c}0.002 \\
(0.002)\end{array}$ & $\begin{array}{c}0.099 * * \\
(0.043)\end{array}$ & $\begin{array}{c}0.000 \\
(0.001)\end{array}$ & $\begin{array}{c}0.043 \\
(0.035)\end{array}$ & $\begin{array}{c}0.000 \\
(0.001)\end{array}$ \\
\hline Birth order & $\begin{array}{c}-0.004 \\
(0.004)\end{array}$ & $\begin{array}{c}-0.681^{* * *} \\
(0.207)\end{array}$ & $\begin{array}{c}-0.008^{* * *} \\
(0.003)\end{array}$ & $\begin{array}{c}-0.294 * * \\
(0.111)\end{array}$ & $\begin{array}{c}-0.006 * * \\
(0.003)\end{array}$ & $\begin{array}{c}-0.212^{* *} \\
(0.091)\end{array}$ & $\begin{array}{c}-0.004 \\
(0.003)\end{array}$ & $\begin{array}{c}-0.319 * * * \\
(0.081)\end{array}$ & $\begin{array}{c}0.001 \\
(0.004)\end{array}$ \\
\hline Urban area & $\begin{array}{c}-0.051^{* * *} \\
(0.006)\end{array}$ & $\begin{array}{c}-5.354^{* * *} \\
(0.665)\end{array}$ & $\begin{array}{c}-0.122^{* * *} \\
(0.015)\end{array}$ & $\begin{array}{c}-2.591 * * * \\
(0.432)\end{array}$ & $\begin{array}{c}-0.132^{* * *} \\
(0.017)\end{array}$ & $\begin{array}{c}-2.513^{* * *} \\
(0.404)\end{array}$ & $\begin{array}{c}-0.032 * * * \\
(0.005)\end{array}$ & $\begin{array}{c}-1.143^{* * *} \\
(0.137)\end{array}$ & $\begin{array}{c}0.032 * * * \\
(0.007)\end{array}$ \\
\hline \multicolumn{10}{|l|}{ Wealth index } \\
\hline 1st quantile & $\begin{array}{c}0.074^{* * *} \\
(0.011)\end{array}$ & $\begin{array}{c}5.990 * * * \\
(0.616)\end{array}$ & $\begin{array}{c}0.129 * * * \\
(0.016)\end{array}$ & $\begin{array}{c}3.174 * * * \\
(0.465)\end{array}$ & $\begin{array}{c}0.134^{* * *} \\
(0.018)\end{array}$ & $\begin{array}{c}2.621^{* * * *} \\
(0.385)\end{array}$ & $\begin{array}{c}0.046^{* * *} \\
(0.010)\end{array}$ & $\begin{array}{c}1.373^{* * *} \\
(0.290)\end{array}$ & $\begin{array}{c}-0.103^{* * *} \\
(0.013)\end{array}$ \\
\hline 2nd quantile & $\begin{array}{c}0.053 * * * \\
(0.009)\end{array}$ & $\begin{array}{c}4.592^{* * *} \\
(0.780)\end{array}$ & $\begin{array}{c}0.099 * * * \\
(0.018)\end{array}$ & $\begin{array}{c}2.432 * * * \\
(0.509)\end{array}$ & $\begin{array}{c}0.104^{* * *} \\
(0.019)\end{array}$ & $\begin{array}{c}1.904^{* * *} \\
(0.437)\end{array}$ & $\begin{array}{c}0.038^{* * *} \\
(0.011)\end{array}$ & $\begin{array}{c}0.942 * * * \\
(0.266)\end{array}$ & $\begin{array}{c}-0.077 * * * \\
(0.014)\end{array}$ \\
\hline 3rd quantile & $\begin{array}{c}0.045^{* * *} \\
(0.009)\end{array}$ & $\begin{array}{c}3.706^{* * *} \\
(0.830)\end{array}$ & $\begin{array}{c}0.086 * * * \\
(0.019)\end{array}$ & $\begin{array}{c}1.864^{* * *} \\
(0.475)\end{array}$ & $\begin{array}{c}0.085^{* * *} \\
(0.020)\end{array}$ & $\begin{array}{c}1.375^{* * *} \\
(0.413)\end{array}$ & $\begin{array}{c}0.032^{* * *} \\
(0.009)\end{array}$ & $\begin{array}{c}0.799 * * * \\
(0.242)\end{array}$ & $\begin{array}{c}-0.050 * * * \\
(0.009)\end{array}$ \\
\hline 4th quantile & $\begin{array}{c}0.022 * * * \\
(0.008)\end{array}$ & $\begin{array}{c}2.257 * * * \\
(0.716)\end{array}$ & $\begin{array}{c}0.047 * * * \\
(0.014)\end{array}$ & $\begin{array}{l}1.127^{* *} \\
(0.417)\end{array}$ & $\begin{array}{c}0.050^{* * *} \\
(0.015)\end{array}$ & $\begin{array}{c}0.826 * * \\
(0.372)\end{array}$ & $\begin{array}{c}0.017 * * \\
(0.007)\end{array}$ & $\begin{array}{c}0.516^{* *} \\
(0.250)\end{array}$ & $\begin{array}{c}-0.032 * * * \\
(0.006)\end{array}$ \\
\hline Constant & $\begin{array}{c}0.292^{* * *} \\
(0.046)\end{array}$ & $\begin{array}{c}-7.723^{* * *} \\
(1.718)\end{array}$ & $\begin{array}{c}-0.071 * * * \\
(0.023)\end{array}$ & $\begin{array}{c}-5.481 * * * \\
(1.126)\end{array}$ & $\begin{array}{c}-0.125^{* * *} \\
(0.027)\end{array}$ & $\begin{array}{c}-4.298 * * * \\
(0.881)\end{array}$ & $\begin{array}{c}0.327 * * * \\
(0.046)\end{array}$ & $\begin{array}{c}0.044 \\
(0.839)\end{array}$ & $\begin{array}{c}-0.176^{* * *} \\
(0.031)\end{array}$ \\
\hline Observations & 247,975 & 246,738 & 249,594 & 249,348 & 247,992 & 247,974 & 248,451 & 248,214 & 168,841 \\
\hline R-squared & 0.258 & 0.244 & 0.239 & 0.132 & 0.216 & 0.113 & 0.241 & 0.177 & 0.219 \\
\hline
\end{tabular}

Robust standard errors are reported in parentheses, clustered at the country level. ${ }^{* * *} \mathrm{p}<0.01,{ }^{* *} \mathrm{p}<0.05, * \mathrm{p}<0.1$

Notes: Dependent variables are dichotomous indicators as well as continuous variables (i.e. hours) for work supply in the last week. School attendance is a dichotomous variable referred to the last year. The sample includes children aged 5-14 in 38 countries. The table reports linear probability model results. Reference categories for reported dummy variables are 'higher education (i.e. more than primary)', 'female', 'female household's head', 'rural area'. Other controls include dummies for missing information on household head's education, wealth index, rural/urban area and country fixed effects. 
Table 18 - Migration-flow relative skill composition (RSC) and child labor (largest sample)

\begin{tabular}{|c|c|c|c|c|c|c|c|c|c|}
\hline & Any work & $\begin{array}{c}(2) \\
\text { Total hours } \\
\text { of work }\end{array}$ & $\begin{array}{c}\text { (3) } \\
\text { Market } \\
\text { work }\end{array}$ & $\begin{array}{c}\text { (4) } \\
\text { Hours in } \\
\text { market } \\
\text { work } \\
\end{array}$ & $\begin{array}{c}\text { (5) } \\
\text { Family } \\
\text { business }\end{array}$ & $\begin{array}{c}\text { (6) } \\
\text { Hours in } \\
\text { family } \\
\text { business }\end{array}$ & Chores & $\begin{array}{c}\text { (8) } \\
\text { Hours in } \\
\text { chores }\end{array}$ & $\begin{array}{c}(9) \\
\text { School } \\
\text { attendance }\end{array}$ \\
\hline$* \mathrm{HhH}$ & -0.0 & -3 & -0 . & -1.404 & -0. & -1.097 & $*$ & -1.5 & -0 \\
\hline low skill & $(0.022)$ & $(2.330)$ & $(0.033)$ & (1.519) & $(0.037)$ & $(1.237)$ & $(0.019)$ & $(0.717)$ & $(0.022)$ \\
\hline HhH low-skilled & $\begin{array}{c}0.024 * * * \\
(0.006)\end{array}$ & $\begin{array}{l}1.346^{* *} \\
(0.578)\end{array}$ & $\begin{array}{c}0.021^{* *} \\
(0.010)\end{array}$ & $\begin{array}{c}0.511 \\
(0.404)\end{array}$ & $\begin{array}{c}0.024^{* *} \\
(0.011)\end{array}$ & $\begin{array}{c}0.267 \\
(0.304)\end{array}$ & $\begin{array}{c}0.025^{* * *} \\
(0.005)\end{array}$ & $\begin{array}{c}0.608 * * * \\
(0.178)\end{array}$ & $\begin{array}{c}-0.027 * * * \\
(0.007)\end{array}$ \\
\hline Age & $\begin{array}{c}0.045^{* * *} \\
(0.005)\end{array}$ & $\begin{array}{c}2.434^{* * *} \\
(0.195)\end{array}$ & $\begin{array}{c}0.033^{* * *} \\
(0.002)\end{array}$ & $\begin{array}{c}1.020 * * * \\
(0.104)\end{array}$ & $\begin{array}{c}0.030 * * * \\
(0.002)\end{array}$ & $\begin{array}{c}0.764^{* * * *} \\
(0.087)\end{array}$ & $\begin{array}{c}0.040^{* * *} \\
(0.005)\end{array}$ & $\begin{array}{c}1.068^{* * *} \\
(0.106)\end{array}$ & $\begin{array}{c}0.040^{* * *} \\
(0.003)\end{array}$ \\
\hline Male & $\begin{array}{c}-0.078 * * * \\
(0.017)\end{array}$ & $\begin{array}{c}-0.581 \\
(0.405)\end{array}$ & $\begin{array}{c}0.035^{* * *} \\
(0.010)\end{array}$ & $\begin{array}{c}1.394^{* * *} \\
(0.347)\end{array}$ & $\begin{array}{c}0.035^{* * *} \\
(0.012)\end{array}$ & $\begin{array}{c}1.072^{* * *} \\
(0.339)\end{array}$ & $\begin{array}{c}-0.125^{* * *} \\
(0.024)\end{array}$ & $\begin{array}{c}-2.807 * * * \\
(0.446)\end{array}$ & $\begin{array}{c}0.016 * * \\
(0.007)\end{array}$ \\
\hline Ever in school & $\begin{array}{c}0.060 * * * \\
(0.010)\end{array}$ & $\begin{array}{c}-2.007 * * \\
(0.747)\end{array}$ & $\begin{array}{c}0.003 \\
(0.009)\end{array}$ & $\begin{array}{c}-1.435^{* * *} \\
(0.384)\end{array}$ & $\begin{array}{c}0.001 \\
(0.008)\end{array}$ & $\begin{array}{c}-1.112^{* * *} \\
(0.365)\end{array}$ & $\begin{array}{c}0.067 * * * \\
(0.010)\end{array}$ & $\begin{array}{c}-0.605^{*} \\
(0.355)\end{array}$ & $\begin{array}{c}0.614^{* * *} \\
(0.018)\end{array}$ \\
\hline HhH male & $\begin{array}{c}0.011^{* *} \\
(0.005)\end{array}$ & $\begin{array}{c}1.001^{* * *} \\
(0.253)\end{array}$ & $\begin{array}{c}0.014^{* *} \\
(0.006)\end{array}$ & $\begin{array}{c}0.441^{* * *} \\
(0.128)\end{array}$ & $\begin{array}{c}0.021^{* * *} \\
(0.007)\end{array}$ & $\begin{array}{c}0.402 * * * \\
(0.134)\end{array}$ & $\begin{array}{c}0.012 * \\
(0.006)\end{array}$ & $\begin{array}{c}0.335^{* *} \\
(0.159)\end{array}$ & $\begin{array}{c}-0.006 \\
(0.004)\end{array}$ \\
\hline Mother lives at home & $\begin{array}{c}-0.011 * * * \\
(0.004) \\
-0.006\end{array}$ & $\begin{array}{c}-0.419 \\
(0.262) \\
0.262\end{array}$ & $\begin{array}{c}-0.000 \\
(0.006) \\
0.001\end{array}$ & $\begin{array}{c}-0.117 \\
(0.162) \\
0.293\end{array}$ & $\begin{array}{c}0.007 \\
(0.005) \\
0.005\end{array}$ & $\begin{array}{c}0.085 \\
(0.121) \\
0.368 * *\end{array}$ & $\begin{array}{c}-0.005 \\
(0.004) \\
-0.009 * *\end{array}$ & $\begin{array}{c}-0.438 * * \\
(0.178) \\
-0.130\end{array}$ & $\begin{array}{c}0.028^{* * *} \\
(0.006) \\
0.010^{* *}\end{array}$ \\
\hline Father lives at home & $(0.004)$ & $(0.420)$ & $(0.007)$ & $(0.179)$ & $(0.006)$ & $(0.157)$ & $(0.004)$ & $(0.200)$ & $(0.005)$ \\
\hline $\begin{array}{l}\text { N. of siblings aged 5- } \\
15\end{array}$ & $\begin{array}{l}-0.001 \\
(0.001)\end{array}$ & $\begin{array}{c}0.151 \\
(0.096)\end{array}$ & $\begin{array}{l}0.003 * \\
(0.002)\end{array}$ & $\begin{array}{c}0.096 \\
(0.066)\end{array}$ & $\begin{array}{l}0.003 * * \\
(0.002)\end{array}$ & $\begin{array}{c}0.070 \\
(0.056)\end{array}$ & $\begin{array}{l}-0.001 \\
(0.001)\end{array}$ & $\begin{array}{c}0.029 \\
(0.025)\end{array}$ & $\begin{array}{c}0.003 \\
(0.002)\end{array}$ \\
\hline $\begin{array}{l}\text { N. of children }<5 \text { y.o. } \\
\text { at home }\end{array}$ & $\begin{array}{l}0.004^{* *} \\
(0.001)\end{array}$ & $\begin{array}{l}0.199 * * \\
(0.094)\end{array}$ & $\begin{array}{l}0.002 * \\
(0.001)\end{array}$ & $\begin{array}{c}0.048 \\
(0.050)\end{array}$ & $\begin{array}{c}0.001 \\
(0.001)\end{array}$ & $\begin{array}{c}0.011 \\
(0.057)\end{array}$ & $\begin{array}{l}0.004 * * \\
(0.002)\end{array}$ & $\begin{array}{c}0.155^{* * *} \\
(0.048)\end{array}$ & $\begin{array}{c}-0.008 * * * \\
(0.003)\end{array}$ \\
\hline $\begin{array}{l}\text { N. of female adults at } \\
\text { home }\end{array}$ & $\begin{array}{c}-0.010^{* * *} \\
(0.002)\end{array}$ & $\begin{array}{c}-0.312 * * * \\
(0.100)\end{array}$ & $\begin{array}{l}-0.001 \\
(0.003)\end{array}$ & $\begin{array}{l}-0.082 \\
(0.070)\end{array}$ & $\begin{array}{l}-0.001 \\
(0.002)\end{array}$ & $\begin{array}{l}-0.100 * \\
(0.055)\end{array}$ & $\begin{array}{c}-0.008 * * * \\
(0.003)\end{array}$ & $\begin{array}{c}-0.247 * * * \\
(0.059)\end{array}$ & $\begin{array}{l}-0.000 \\
(0.001)\end{array}$ \\
\hline Household size & $\begin{array}{c}0.002 \\
(0.001)\end{array}$ & $\begin{array}{l}0.173 * \\
(0.090)\end{array}$ & $\begin{array}{c}0.002 \\
(0.002)\end{array}$ & $\begin{array}{c}0.084 \\
(0.056)\end{array}$ & $\begin{array}{c}0.002 \\
(0.002)\end{array}$ & $\begin{array}{l}0.099 * * \\
(0.043)\end{array}$ & $\begin{array}{c}0.000 \\
(0.001)\end{array}$ & $\begin{array}{c}0.042 \\
(0.035)\end{array}$ & $\begin{array}{c}0.000 \\
(0.001)\end{array}$ \\
\hline Birth & $\begin{array}{l}-0.004 \\
(0.004)\end{array}$ & $\begin{array}{c}-0.679 * * * \\
(0.207)\end{array}$ & $\begin{array}{c}-0.008 * * * \\
(0.003)\end{array}$ & $\begin{array}{c}-0.294^{* *} \\
(0.111)\end{array}$ & $\begin{array}{c}-0.006^{* *} \\
(0.003)\end{array}$ & $\begin{array}{c}-0.212 * * \\
(0.091)\end{array}$ & $\begin{array}{l}-0.004 \\
(0.003)\end{array}$ & $\begin{array}{c}-0.318 * * * \\
(0.081)\end{array}$ & $\begin{array}{c}0.001 \\
(0.004)\end{array}$ \\
\hline Urban area & $\begin{array}{c}-0.051^{* * *} \\
(0.006)\end{array}$ & $\begin{array}{c}-5.354 * * * \\
(0.664)\end{array}$ & $\begin{array}{c}-0.123 * * * \\
(0.015)\end{array}$ & $\begin{array}{c}-2.591 * * * \\
(0.431)\end{array}$ & $\begin{array}{c}-0.132 * * * \\
(0.017)\end{array}$ & $\begin{array}{c}-2.513^{* * * *} \\
(0.403)\end{array}$ & $\begin{array}{c}-0.032^{* * *} \\
(0.005)\end{array}$ & $\begin{array}{c}-1.144^{* * *} \\
(0.137)\end{array}$ & $\begin{array}{c}0.032 * * * \\
(0.007)\end{array}$ \\
\hline \multicolumn{10}{|l|}{ Wealth index } \\
\hline 1st quantile & $\begin{array}{c}0.074 * * * \\
(0.011)\end{array}$ & $\begin{array}{c}5.985 * * * \\
(0.617)\end{array}$ & $\begin{array}{c}0.129 * * * \\
(0.016)\end{array}$ & $\begin{array}{c}3.173 * * * \\
(0.464)\end{array}$ & $\begin{array}{c}0.134^{* * *} \\
(0.018)\end{array}$ & $\begin{array}{c}2.620^{* * * *} \\
(0.384)\end{array}$ & $\begin{array}{c}0.046^{* * * *} \\
(0.010)\end{array}$ & $\begin{array}{c}1.371^{* * *} \\
(0.290)\end{array}$ & $\begin{array}{c}-0.103 * * * \\
(0.013)\end{array}$ \\
\hline 2nd quantile & $\begin{array}{c}0.053^{* * *} \\
(0.009)\end{array}$ & $\begin{array}{c}4.587 * * * \\
(0.778)\end{array}$ & $\begin{array}{c}0.099 * * * \\
(0.018)\end{array}$ & $\begin{array}{c}2.430 * * * \\
(0.508)\end{array}$ & $\begin{array}{c}0.104^{* * *} \\
(0.019)\end{array}$ & $\begin{array}{c}1.902 * * * \\
(0.436)\end{array}$ & $\begin{array}{c}0.038 * * * \\
(0.011)\end{array}$ & $\begin{array}{c}0.941^{* * *} \\
(0.266)\end{array}$ & $\begin{array}{c}-0.077 * * * \\
(0.014)\end{array}$ \\
\hline 3rd quantile & $\begin{array}{c}0.045^{* * * *} \\
(0.009)\end{array}$ & $\begin{array}{c}3.702 * * * \\
(0.832)\end{array}$ & $\begin{array}{c}0.086^{* * *} \\
(0.019)\end{array}$ & $\begin{array}{c}1.862 * * * \\
(0.476)\end{array}$ & $\begin{array}{c}0.085^{* * *} \\
(0.020)\end{array}$ & $\begin{array}{c}1.373^{* * * *} \\
(0.413)\end{array}$ & $\begin{array}{c}0.032^{* * * *} \\
(0.009)\end{array}$ & $\begin{array}{c}0.798^{* * *} \\
(0.242)\end{array}$ & $\begin{array}{c}-0.050 * * * \\
(0.009)\end{array}$ \\
\hline 4th quantile & $\begin{array}{c}0.022 * * * \\
(0.008)\end{array}$ & $\begin{array}{c}2.257 * * * \\
(0.717)\end{array}$ & $\begin{array}{c}0.047^{* * *} \\
(0.014)\end{array}$ & $\begin{array}{l}1.127 * * \\
(0.418)\end{array}$ & $\begin{array}{c}0.050 * * * \\
(0.015)\end{array}$ & $\begin{array}{c}0.826 * * \\
(0.373)\end{array}$ & $\begin{array}{c}0.017 * * \\
(0.007)\end{array}$ & $\begin{array}{c}0.518^{* *} \\
(0.250)\end{array}$ & $\begin{array}{c}-0.032 * * * \\
(0.006)\end{array}$ \\
\hline Constant & $\begin{array}{c}0.292 * * * \\
(0.046)\end{array}$ & $\begin{array}{c}-7.714 * * * \\
(1.716)\end{array}$ & $\begin{array}{c}-0.071 * * * \\
(0.023)\end{array}$ & $\begin{array}{c}-5.479 * * * \\
(1.124)\end{array}$ & $\begin{array}{c}-0.124 * * * \\
(0.026)\end{array}$ & $\begin{array}{c}-4.297 * * * \\
(0.881)\end{array}$ & $\begin{array}{c}0.327 * * * \\
(0.046)\end{array}$ & $\begin{array}{c}0.050 \\
(0.839)\end{array}$ & $\begin{array}{c}-0.176^{* * *} \\
(0.031)\end{array}$ \\
\hline Observations & 247,975 & 246,738 & 249,594 & 249,348 & 247,992 & 247,974 & 248,451 & 248,214 & 168,841 \\
\hline R-squared & 0.258 & 0.245 & 0.239 & 0.132 & 0.216 & 0.113 & 0.241 & 0.177 & 0.219 \\
\hline
\end{tabular}

Robust standard errors are reported in parentheses, clustered at the country level. $* * * p<0.01, * * p<0.05$, * $p<0.1$

Notes: Dependent variables are dichotomous indicators as well as continuous variables (i.e. hours) for work supply in the last week. School attendance is a dichotomous variable referred to the last year. The sample includes children aged 5-14 in 38 countries. The table reports linear probability model results. The Relative Skill Composition (RSC) index is the ratio of the flow of low-skilled to skilled labor in the migrant relative to the resident population. Reference categories for reported dummy variables are 'higher education', 'female', 'female household's head', 'rural area'. Other controls include dummies for missing information on household head's education, wealth index, rural/urban area and country fixed effects. 
Table 19 - Lagged migration outflows and child labor (largest sample)

$$
\text { (1) }
$$

(2)

Any work
Total hours Market of work

\section{(3)}

(4)

Hours in work market work

\section{(5)}

Family
business

(7) (6) Hours in family business
Chores
(8)

Hours in

School chores attendance

\begin{tabular}{|c|c|c|c|c|c|c|c|c|c|}
\hline $\begin{array}{l}\text { Mig rate } \\
\text { lagged*HhH low sk }\end{array}$ & $\begin{array}{c}-0.126 * * \\
(0.057)\end{array}$ & $\begin{array}{l}-6.352 * \\
(3.234)\end{array}$ & $\begin{array}{l}-0.080 \\
(0.065)\end{array}$ & $\begin{array}{l}-3.018 \\
(2.092)\end{array}$ & $\begin{array}{l}-0.092 \\
(0.073)\end{array}$ & $\begin{array}{l}-2.146 \\
(1.641)\end{array}$ & $\begin{array}{c}-0.116^{* *} \\
(0.049)\end{array}$ & $\begin{array}{c}-2.374^{* *} \\
(0.879)\end{array}$ & $\begin{array}{c}0.074 * * \\
(0.031)\end{array}$ \\
\hline HhH low-skilled & $\begin{array}{c}0.020 * * * \\
(0.006)\end{array}$ & $\begin{array}{l}0.944 * \\
(0.485)\end{array}$ & $\begin{array}{l}0.017 * * \\
(0.008)\end{array}$ & $\begin{array}{c}0.384 \\
(0.332)\end{array}$ & $\begin{array}{l}0.019 * * \\
(0.009)\end{array}$ & $\begin{array}{c}0.163 \\
(0.270)\end{array}$ & $\begin{array}{c}0.020 * * * \\
(0.004)\end{array}$ & $\begin{array}{c}0.446^{* * *} \\
(0.154)\end{array}$ & $\begin{array}{c}-0.030 * * * \\
(0.006)\end{array}$ \\
\hline Age & $\begin{array}{c}0.045^{* * *} \\
(0.005)\end{array}$ & $\begin{array}{c}2.433^{* * *} \\
(0.195)\end{array}$ & $\begin{array}{c}0.033^{* * *} \\
(0.002)\end{array}$ & $\begin{array}{c}1.020 * * * \\
(0.104)\end{array}$ & $\begin{array}{c}0.030^{* * *} \\
(0.002)\end{array}$ & $\begin{array}{c}0.764^{* * *} \\
(0.087)\end{array}$ & $\begin{array}{c}0.040 * * * \\
(0.005)\end{array}$ & $\begin{array}{c}1.067^{* * * *} \\
(0.106)\end{array}$ & $\begin{array}{c}0.040 * * * \\
(0.003)\end{array}$ \\
\hline Male & $\begin{array}{c}-0.078 * * * \\
(0.017)\end{array}$ & $\begin{array}{l}-0.581 \\
(0.405)\end{array}$ & $\begin{array}{c}0.035^{* * *} \\
(0.010)\end{array}$ & $\begin{array}{c}1.394^{* * *} \\
(0.347)\end{array}$ & $\begin{array}{c}0.035^{* * *} \\
(0.012)\end{array}$ & $\begin{array}{c}1.072 * * * \\
(0.339)\end{array}$ & $\begin{array}{c}-0.125 * * * \\
(0.024)\end{array}$ & $\begin{array}{c}-2.807 * * * \\
(0.446)\end{array}$ & $\begin{array}{l}0.016 * * \\
(0.007)\end{array}$ \\
\hline Ever in school & $\begin{array}{c}0.060 * * * \\
(0.010)\end{array}$ & $\begin{array}{c}-2.006^{* *} \\
(0.746)\end{array}$ & $\begin{array}{c}0.003 \\
(0.009)\end{array}$ & $\begin{array}{c}-1.434 * * * \\
(0.385)\end{array}$ & $\begin{array}{c}0.001 \\
(0.008)\end{array}$ & $\begin{array}{c}-1.112^{* * *} \\
(0.365)\end{array}$ & $\begin{array}{c}0.067 * * * \\
(0.010)\end{array}$ & $\begin{array}{l}-0.605^{*} \\
(0.355)\end{array}$ & $\begin{array}{c}0.614 * * * \\
(0.018)\end{array}$ \\
\hline HhH male & $\begin{array}{l}0.010 * \\
(0.005)\end{array}$ & $\begin{array}{c}0.979 * * * \\
(0.245)\end{array}$ & $\begin{array}{l}0.014 * * \\
(0.006)\end{array}$ & $\begin{array}{c}0.434^{* * *} \\
(0.125)\end{array}$ & $\begin{array}{c}0.021^{* * *} \\
(0.007)\end{array}$ & $\begin{array}{c}0.396 * * * \\
(0.130)\end{array}$ & $\begin{array}{l}0.012^{*} \\
(0.006)\end{array}$ & $\begin{array}{l}0.326^{* *} \\
(0.158)\end{array}$ & $\begin{array}{l}-0.006 \\
(0.004)\end{array}$ \\
\hline Mother lives at home & $\begin{array}{c}-0.011^{* * *} \\
(0.004)\end{array}$ & $\begin{array}{l}-0.425 \\
(0.263)\end{array}$ & $\begin{array}{l}-0.000 \\
(0.006)\end{array}$ & $\begin{array}{l}-0.120 \\
(0.162)\end{array}$ & $\begin{array}{c}0.007 \\
(0.005)\end{array}$ & $\begin{array}{c}0.084 \\
(0.122)\end{array}$ & $\begin{array}{l}-0.005 \\
(0.004)\end{array}$ & $\begin{array}{c}-0.441^{* *} \\
(0.179)\end{array}$ & $\begin{array}{c}0.028 * * * \\
(0.006)\end{array}$ \\
\hline Father lives at home & $\begin{array}{l}-0.006 \\
(0.004)\end{array}$ & $\begin{array}{c}0.272 \\
(0.420)\end{array}$ & $\begin{array}{c}0.001 \\
(0.007)\end{array}$ & $\begin{array}{c}0.297 \\
(0.178)\end{array}$ & $\begin{array}{c}0.005 \\
(0.006)\end{array}$ & $\begin{array}{c}0.371 * * \\
(0.156)\end{array}$ & $\begin{array}{c}-0.009 * * \\
(0.004)\end{array}$ & $\begin{array}{l}-0.125 \\
(0.200)\end{array}$ & $\begin{array}{c}0.010^{* *} \\
(0.005)\end{array}$ \\
\hline $\begin{array}{l}\text { N. of siblings aged 5- } \\
15\end{array}$ & $\begin{array}{l}-0.001 \\
(0.001)\end{array}$ & $\begin{array}{c}0.151 \\
(0.095)\end{array}$ & $\begin{array}{l}0.003^{*} \\
(0.002)\end{array}$ & $\begin{array}{c}0.096 \\
(0.066)\end{array}$ & $\begin{array}{l}0.003^{* *} \\
(0.002)\end{array}$ & $\begin{array}{c}0.069 \\
(0.056)\end{array}$ & $\begin{array}{l}-0.001 \\
(0.001)\end{array}$ & $\begin{array}{c}0.029 \\
(0.025)\end{array}$ & $\begin{array}{c}0.003 \\
(0.002)\end{array}$ \\
\hline $\begin{array}{l}\text { N. of children }<5 \text { y.o. } \\
\text { at home }\end{array}$ & $\begin{array}{l}0.004^{* *} \\
(0.001)\end{array}$ & $\begin{array}{l}0.199 * * \\
(0.094)\end{array}$ & $\begin{array}{l}0.002 * \\
(0.001)\end{array}$ & $\begin{array}{c}0.047 \\
(0.050)\end{array}$ & $\begin{array}{c}0.001 \\
(0.001)\end{array}$ & $\begin{array}{c}0.010 \\
(0.057)\end{array}$ & $\begin{array}{l}0.004^{* *} \\
(0.002)\end{array}$ & $\begin{array}{c}0.154^{* * *} \\
(0.048)\end{array}$ & $\begin{array}{c}-0.008 * * * \\
(0.003)\end{array}$ \\
\hline $\begin{array}{l}\text { N. of female adults at } \\
\text { home }\end{array}$ & $\begin{array}{c}-0.010 * * * \\
(0.002)\end{array}$ & $\begin{array}{c}-0.310^{* * *} \\
(0.100)\end{array}$ & $\begin{array}{l}-0.001 \\
(0.003)\end{array}$ & $\begin{array}{c}-0.081 \\
(0.070)\end{array}$ & $\begin{array}{c}-0.001 \\
(0.002)\end{array}$ & $\begin{array}{l}-0.100 * \\
(0.056)\end{array}$ & $\begin{array}{c}-0.008 * * * \\
(0.003)\end{array}$ & $\begin{array}{c}-0.246 * * * \\
(0.059)\end{array}$ & $\begin{array}{c}-0.000 \\
(0.001)\end{array}$ \\
\hline Household size & $\begin{array}{c}0.002 \\
(0.001)\end{array}$ & $\begin{array}{l}0.175^{*} \\
(0.091)\end{array}$ & $\begin{array}{c}0.002 \\
(0.002)\end{array}$ & $\begin{array}{c}0.085 \\
(0.056)\end{array}$ & $\begin{array}{c}0.002 \\
(0.002)\end{array}$ & $\begin{array}{c}0.099 * * \\
(0.043)\end{array}$ & $\begin{array}{c}0.000 \\
(0.001)\end{array}$ & $\begin{array}{c}0.043 \\
(0.035)\end{array}$ & $\begin{array}{c}0.000 \\
(0.001)\end{array}$ \\
\hline Birth order & $\begin{array}{c}-0.004 \\
(0.004)\end{array}$ & $\begin{array}{c}-0.681^{* * *} \\
(0.207)\end{array}$ & $\begin{array}{c}-0.008^{* * *} \\
(0.003)\end{array}$ & $\begin{array}{c}-0.294^{* *} \\
(0.111)\end{array}$ & $\begin{array}{c}-0.006 * * \\
(0.003)\end{array}$ & $\begin{array}{c}-0.212 * * \\
(0.091)\end{array}$ & $\begin{array}{c}-0.004 \\
(0.003)\end{array}$ & $\begin{array}{c}-0.319 * * * \\
(0.081)\end{array}$ & $\begin{array}{c}0.001 \\
(0.004)\end{array}$ \\
\hline Urban area & $\begin{array}{c}-0.052 * * * \\
(0.006)\end{array}$ & $\begin{array}{c}-5.358 * * * \\
(0.665)\end{array}$ & $\begin{array}{c}-0.123^{* * *} \\
(0.015)\end{array}$ & $\begin{array}{c}-2.592 * * * \\
(0.433)\end{array}$ & $\begin{array}{c}-0.132 * * * \\
(0.017)\end{array}$ & $\begin{array}{c}-2.514^{* * *} \\
(0.404)\end{array}$ & $\begin{array}{c}-0.032 * * * \\
(0.005)\end{array}$ & $\begin{array}{c}-1.145^{* * *} \\
(0.137)\end{array}$ & $\begin{array}{c}0.032 * * * \\
(0.007)\end{array}$ \\
\hline \multicolumn{10}{|l|}{ Wealth index } \\
\hline 1st quar & $\begin{array}{c}0.074^{* * *} \\
(0.011)\end{array}$ & $\begin{array}{c}5.987 * * * \\
(0.616)\end{array}$ & $\begin{array}{c}0.129 * * * \\
(0.016)\end{array}$ & $\begin{array}{c}3.173^{* * *} \\
(0.464)\end{array}$ & $\begin{array}{c}0.134^{* * *} \\
(0.018)\end{array}$ & $\begin{array}{c}2.621^{* * *} \\
(0.384)\end{array}$ & $\begin{array}{c}0.046^{* * *} \\
(0.010)\end{array}$ & $\begin{array}{c}1.372^{* * *} \\
(0.290)\end{array}$ & $\begin{array}{c}-0.103^{* * *} \\
(0.013)\end{array}$ \\
\hline 2nd quantile & $\begin{array}{c}0.053^{* * *} \\
(0.009)\end{array}$ & $\begin{array}{c}4.591^{* * *} \\
(0.780)\end{array}$ & $\begin{array}{c}0.099 * * * \\
(0.018)\end{array}$ & $\begin{array}{c}2.431^{* * *} \\
(0.509)\end{array}$ & $\begin{array}{c}0.104^{* * *} \\
(0.019)\end{array}$ & $\begin{array}{c}1.903^{* * *} \\
(0.437)\end{array}$ & $\begin{array}{c}0.038 * * * \\
(0.011)\end{array}$ & $\begin{array}{c}0.942 * * * \\
(0.266)\end{array}$ & $\begin{array}{c}-0.077^{* * *} \\
(0.014)\end{array}$ \\
\hline 3rd quantile & $\begin{array}{c}0.045^{* * *} \\
(0.009)\end{array}$ & $\begin{array}{c}3.705^{* * *} \\
(0.830)\end{array}$ & $\begin{array}{c}0.086^{* * *} \\
(0.019)\end{array}$ & $\begin{array}{c}1.862^{* * *} \\
(0.475)\end{array}$ & $\begin{array}{c}0.085^{* * *} \\
(0.020)\end{array}$ & $\begin{array}{c}1.373^{* * *} \\
(0.413)\end{array}$ & $\begin{array}{c}0.032 * * * \\
(0.009)\end{array}$ & $\begin{array}{c}0.799 * * * \\
(0.242)\end{array}$ & $\begin{array}{c}-0.050 * * * \\
(0.009)\end{array}$ \\
\hline 4th quantile & $\begin{array}{c}0.022^{* * *} \\
(0.008)\end{array}$ & $\begin{array}{c}2.255^{* * *} \\
(0.716)\end{array}$ & $\begin{array}{c}0.047 * * * \\
(0.014)\end{array}$ & $\begin{array}{l}1.125^{* *} \\
(0.416)\end{array}$ & $\begin{array}{c}0.050^{* * *} \\
(0.015)\end{array}$ & $\begin{array}{c}0.824 * * \\
(0.372)\end{array}$ & $\begin{array}{c}0.017^{* *} \\
(0.007)\end{array}$ & $\begin{array}{c}0.516^{* *} \\
(0.250)\end{array}$ & $\begin{array}{c}-0.032 * * * \\
(0.006)\end{array}$ \\
\hline Constant & $\begin{array}{c}0.292^{* * *} \\
(0.046)\end{array}$ & $\begin{array}{c}-7.719 * * * \\
(1.716)\end{array}$ & $\begin{array}{c}-0.071^{* * *} \\
(0.023)\end{array}$ & $\begin{array}{c}-5.483 * * * \\
(1.124)\end{array}$ & $\begin{array}{c}-0.125^{* * *} \\
(0.027)\end{array}$ & $\begin{array}{c}-4.300^{* * *} \\
(0.880)\end{array}$ & $\begin{array}{c}0.327^{* * *} \\
(0.046)\end{array}$ & $\begin{array}{c}0.048 \\
(0.839)\end{array}$ & $\begin{array}{c}-0.176^{* * *} \\
(0.031)\end{array}$ \\
\hline Obser & 247,975 & 246,738 & 249,594 & 249,348 & 247,992 & 247,974 & 248,451 & 248,214 & 168,841 \\
\hline R-squared & 0.258 & 0.244 & 0.239 & 0.132 & 0.216 & 0.113 & 0.241 & 0.177 & 0.219 \\
\hline
\end{tabular}

Robust standard errors are reported in parentheses, clustered at the country level. ${ }^{* * *} \mathrm{p}<0.01,{ }^{* *} \mathrm{p}<0.05,{ }^{*} \mathrm{p}<0.1$

Notes: Dependent variables are dichotomous indicators as well as continuous variables (i.e. hours) for work supply in the last week. School attendance is a dichotomous variable referred to the last year. The sample includes children aged 5-14 in 38 countries. The table reports linear probability model results. Reference categories for reported dummy variables are 'higher education (i.e. more than primary)', 'female', 'female household's head', 'rural area'. Other controls include dummies for missing information on household head's education, wealth index, rural/urban area and country fixed effects. 
Table 20 - Skill composition of lagged migration outflows and child labor (largest sample)

$\begin{array}{lllll}(1) & (2) & \text { (3) (4) }\end{array}$

(7)

(8)

(9)

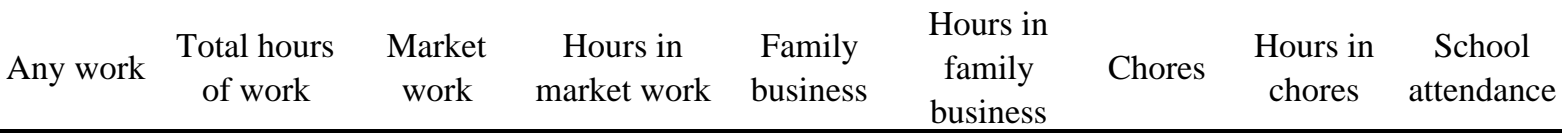

\begin{tabular}{|c|c|c|c|c|c|c|c|c|c|}
\hline Mig low skill & $-0.059 *$ & $-6.407 * *$ & -0.053 & -1.363 & -0.056 & -2.038 & $-0.047^{*}$ & $-3.832 * * *$ & -0.054 \\
\hline lag*HhH low sk & $(0.033)$ & $(2.459)$ & $(0.044)$ & $(1.480)$ & $(0.052)$ & (1.327) & $(0.028)$ & $(0.904)$ & $(0.037)$ \\
\hline HhH low-skilled & $\begin{array}{c}0.037 * * * \\
(0.013)\end{array}$ & $\begin{array}{c}3.007 * * * \\
(0.759)\end{array}$ & $\begin{array}{l}0.034^{* *} \\
(0.015)\end{array}$ & $\begin{array}{l}0.790 * \\
(0.408)\end{array}$ & $\begin{array}{l}0.037 * * \\
(0.018)\end{array}$ & $\begin{array}{l}0.817 * * \\
(0.397)\end{array}$ & $\begin{array}{c}0.034^{* * *} \\
(0.011)\end{array}$ & $\begin{array}{c}1.710 * * * \\
(0.365)\end{array}$ & $\begin{array}{l}-0.010 \\
(0.013)\end{array}$ \\
\hline Age & $\begin{array}{c}0.045^{* * *} \\
(0.005)\end{array}$ & $\begin{array}{c}2.432 * * * \\
(0.195)\end{array}$ & $\begin{array}{c}0.033 * * * \\
(0.002)\end{array}$ & $\begin{array}{c}1.020 * * * \\
(0.104)\end{array}$ & $\begin{array}{c}0.030 * * * \\
(0.002)\end{array}$ & $\begin{array}{c}0.764 * * * \\
(0.087)\end{array}$ & $\begin{array}{c}0.040 * * * \\
(0.005)\end{array}$ & $\begin{array}{c}1.067^{* * *} \\
(0.106)\end{array}$ & $\begin{array}{c}0.040 * * * \\
(0.003)\end{array}$ \\
\hline Male & $\begin{array}{c}-0.078 * * * \\
(0.017)\end{array}$ & $\begin{array}{l}-0.579 \\
(0.405)\end{array}$ & $\begin{array}{c}0.035 * * * \\
(0.010)\end{array}$ & $\begin{array}{c}1.394 * * * \\
(0.348)\end{array}$ & $\begin{array}{c}0.035 * * * \\
(0.012)\end{array}$ & $\begin{array}{c}1.072 * * * \\
(0.339)\end{array}$ & $\begin{array}{c}-0.125 * * * \\
(0.024)\end{array}$ & $\begin{array}{c}-2.805 * * * \\
(0.446)\end{array}$ & $\begin{array}{c}0.016 * * \\
(0.007)\end{array}$ \\
\hline Ever in school & $\begin{array}{c}0.060^{* * *} \\
(0.010)\end{array}$ & $\begin{array}{c}-2.012 * * \\
(0.743)\end{array}$ & $\begin{array}{c}0.003 \\
(0.009)\end{array}$ & $\begin{array}{c}-1.436 * * * \\
(0.384)\end{array}$ & $\begin{array}{c}0.001 \\
(0.008)\end{array}$ & $\begin{array}{c}-1.114^{* * *} \\
(0.364)\end{array}$ & $\begin{array}{c}0.067 * * * \\
(0.010)\end{array}$ & $\begin{array}{l}-0.608 * \\
(0.353)\end{array}$ & $\begin{array}{c}0.614^{* * *} \\
(0.018)\end{array}$ \\
\hline HhH male & $\begin{array}{l}0.010^{*} \\
(0.005)\end{array}$ & $\begin{array}{c}0.964^{* * *} \\
(0.245)\end{array}$ & $\begin{array}{l}0.014 * * \\
(0.006)\end{array}$ & $\begin{array}{c}0.429 * * * \\
(0.125)\end{array}$ & $\begin{array}{c}0.021 * * * \\
(0.007)\end{array}$ & $\begin{array}{c}0.391^{* * *} \\
(0.130)\end{array}$ & $\begin{array}{l}0.012^{*} \\
(0.006)\end{array}$ & $\begin{array}{l}0.318^{*} \\
(0.158)\end{array}$ & $\begin{array}{l}-0.006 \\
(0.004)\end{array}$ \\
\hline $\begin{array}{l}\text { Mother lives at } \\
\text { home }\end{array}$ & $\begin{array}{c}-0.011 * * * \\
(0.004)\end{array}$ & $\begin{array}{l}-0.429 \\
(0.261)\end{array}$ & $\begin{array}{l}-0.000 \\
(0.006)\end{array}$ & $\begin{array}{l}-0.120 \\
(0.161)\end{array}$ & $\begin{array}{c}0.007 \\
(0.005)\end{array}$ & $\begin{array}{c}0.082 \\
(0.122)\end{array}$ & $\begin{array}{l}-0.005 \\
(0.004)\end{array}$ & $\begin{array}{c}-0.443 * * \\
(0.177)\end{array}$ & $\begin{array}{c}0.028 * * * \\
(0.006)\end{array}$ \\
\hline $\begin{array}{l}\text { Father lives at } \\
\text { home }\end{array}$ & $\begin{array}{l}-0.006 \\
(0.004)\end{array}$ & $\begin{array}{c}0.276 \\
(0.419)\end{array}$ & $\begin{array}{c}0.001 \\
(0.007)\end{array}$ & $\begin{array}{c}0.298 \\
(0.178)\end{array}$ & $\begin{array}{c}0.005 \\
(0.006)\end{array}$ & $\begin{array}{l}0.372 * * \\
(0.157)\end{array}$ & $\begin{array}{c}-0.009 * * \\
(0.004)\end{array}$ & $\begin{array}{l}-0.123 \\
(0.200)\end{array}$ & $\begin{array}{l}0.010 * * \\
(0.005)\end{array}$ \\
\hline $\begin{array}{l}\text { N. of siblings } \\
\text { aged 5-15 }\end{array}$ & $\begin{array}{c}-0.001 \\
(0.001)\end{array}$ & $\begin{array}{c}0.151 \\
(0.095)\end{array}$ & $\begin{array}{l}0.003 * \\
(0.002)\end{array}$ & $\begin{array}{c}0.096 \\
(0.066)\end{array}$ & $\begin{array}{l}0.003 * * \\
(0.002)\end{array}$ & $\begin{array}{c}0.069 \\
(0.056)\end{array}$ & $\begin{array}{c}-0.001 \\
(0.001)\end{array}$ & $\begin{array}{c}0.029 \\
(0.025)\end{array}$ & $\begin{array}{c}0.003 \\
(0.002)\end{array}$ \\
\hline $\begin{array}{l}\text { N. of children }<5 \\
\text { y.o. at home }\end{array}$ & $\begin{array}{l}0.004^{* *} \\
(0.001)\end{array}$ & $\begin{array}{l}0.197 * * \\
(0.094)\end{array}$ & $\begin{array}{l}0.002 * \\
(0.001)\end{array}$ & $\begin{array}{c}0.047 \\
(0.050)\end{array}$ & $\begin{array}{c}0.001 \\
(0.001)\end{array}$ & $\begin{array}{c}0.010 \\
(0.057)\end{array}$ & $\begin{array}{l}0.004^{* *} \\
(0.002)\end{array}$ & $\begin{array}{c}0.153^{* * *} \\
(0.048)\end{array}$ & $\begin{array}{c}-0.008 * * * \\
(0.003)\end{array}$ \\
\hline $\begin{array}{l}\text { N. of female } \\
\text { adults at home }\end{array}$ & $\begin{array}{c}-0.010 * * * \\
(0.002)\end{array}$ & $\begin{array}{c}-0.310 * * * \\
(0.100)\end{array}$ & $\begin{array}{l}-0.001 \\
(0.003)\end{array}$ & $\begin{array}{l}-0.081 \\
(0.070)\end{array}$ & $\begin{array}{l}-0.001 \\
(0.002)\end{array}$ & $\begin{array}{l}-0.100 * \\
(0.055)\end{array}$ & $\begin{array}{c}-0.008 * * * \\
(0.003)\end{array}$ & $\begin{array}{c}-0.246 * * * \\
(0.059)\end{array}$ & $\begin{array}{l}-0.000 \\
(0.001)\end{array}$ \\
\hline Household size & $\begin{array}{c}0.002 \\
(0.001)\end{array}$ & $\begin{array}{l}0.175^{*} \\
(0.090)\end{array}$ & $\begin{array}{c}0.002 \\
(0.002)\end{array}$ & $\begin{array}{c}0.085 \\
(0.056)\end{array}$ & $\begin{array}{c}0.002 \\
(0.002)\end{array}$ & $\begin{array}{c}0.099 * * \\
(0.043)\end{array}$ & $\begin{array}{c}0.000 \\
(0.001)\end{array}$ & $\begin{array}{c}0.043 \\
(0.035)\end{array}$ & $\begin{array}{c}0.000 \\
(0.001)\end{array}$ \\
\hline Birth order & $\begin{array}{c}-0.004 \\
(0.004)\end{array}$ & $\begin{array}{c}-0.684^{* * *} \\
(0.207)\end{array}$ & $\begin{array}{c}-0.008^{* * *} \\
(0.003)\end{array}$ & $\begin{array}{c}-0.295^{* *} \\
(0.111)\end{array}$ & $\begin{array}{c}-0.006^{* *} \\
(0.003)\end{array}$ & $\begin{array}{c}-0.213^{* *} \\
(0.091)\end{array}$ & $\begin{array}{c}-0.004 \\
(0.003)\end{array}$ & $\begin{array}{c}-0.320 * * * \\
(0.081)\end{array}$ & $\begin{array}{c}0.001 \\
(0.004)\end{array}$ \\
\hline Urban area & $\begin{array}{c}-0.051^{* * *} \\
(0.006)\end{array}$ & $\begin{array}{c}-5.351^{* * *} \\
(0.663)\end{array}$ & $\begin{array}{c}-0.122^{* * *} \\
(0.015)\end{array}$ & $\begin{array}{c}-2.591 * * * \\
(0.433)\end{array}$ & $\begin{array}{c}-0.132^{* * *} \\
(0.017)\end{array}$ & $\begin{array}{c}-2.511^{* * *} \\
(0.403)\end{array}$ & $\begin{array}{c}-0.032 * * * \\
(0.005)\end{array}$ & $\begin{array}{c}-1.141^{* * *} \\
(0.135)\end{array}$ & $\begin{array}{c}0.032^{* * *} \\
(0.007)\end{array}$ \\
\hline \multicolumn{10}{|l|}{ Wealth index } \\
\hline 1st quantile & $\begin{array}{c}0.074^{* * *} \\
(0.011)\end{array}$ & $\begin{array}{c}5.987 * * * \\
(0.619)\end{array}$ & $\begin{array}{c}0.129 * * * \\
(0.016)\end{array}$ & $\begin{array}{c}3.174^{* * *} \\
(0.465)\end{array}$ & $\begin{array}{c}0.134^{* * *} \\
(0.018)\end{array}$ & $\begin{array}{c}2.621^{* * *} \\
(0.385)\end{array}$ & $\begin{array}{c}0.046 * * * \\
(0.010)\end{array}$ & $\begin{array}{c}1.371^{* * *} \\
(0.288)\end{array}$ & $\begin{array}{c}-0.103^{* * *} \\
(0.013)\end{array}$ \\
\hline 2nd quantile & $\begin{array}{c}0.053^{* * *} \\
(0.009)\end{array}$ & $\begin{array}{c}4.587 * * * \\
(0.782)\end{array}$ & $\begin{array}{c}0.099 * * * \\
(0.018)\end{array}$ & $\begin{array}{c}2.432 * * * \\
(0.511)\end{array}$ & $\begin{array}{c}0.104 * * * \\
(0.020)\end{array}$ & $\begin{array}{c}1.902 * * * \\
(0.439)\end{array}$ & $\begin{array}{c}0.038 * * * \\
(0.011)\end{array}$ & $\begin{array}{c}0.939 * * * \\
(0.265)\end{array}$ & $\begin{array}{c}-0.078 * * * \\
(0.014)\end{array}$ \\
\hline 3rd quantile & $\begin{array}{c}0.045^{* * *} \\
(0.009)\end{array}$ & $\begin{array}{c}3.702 * * * \\
(0.835)\end{array}$ & $\begin{array}{c}0.086^{* * *} \\
(0.019)\end{array}$ & $\begin{array}{c}1.863^{* * *} \\
(0.478)\end{array}$ & $\begin{array}{c}0.085^{* * *} \\
(0.020)\end{array}$ & $\begin{array}{c}1.373^{* * *} \\
(0.415)\end{array}$ & $\begin{array}{c}0.032 * * * \\
(0.009)\end{array}$ & $\begin{array}{c}0.796^{* * *} \\
(0.242)\end{array}$ & $\begin{array}{c}-0.050 * * * \\
(0.009)\end{array}$ \\
\hline 4th quantile & $\begin{array}{c}0.022^{* * *} \\
(0.008)\end{array}$ & $\begin{array}{c}2.256^{* * *} \\
(0.719)\end{array}$ & $\begin{array}{c}0.047 * * * \\
(0.014)\end{array}$ & $\begin{array}{l}1.128 * * \\
(0.419)\end{array}$ & $\begin{array}{c}0.050 * * * \\
(0.015)\end{array}$ & $\begin{array}{c}0.825 * * \\
(0.373)\end{array}$ & $\begin{array}{c}0.017^{* *} \\
(0.007)\end{array}$ & $\begin{array}{c}0.516^{* *} \\
(0.250)\end{array}$ & $\begin{array}{c}-0.032 * * * \\
(0.006)\end{array}$ \\
\hline Constant & $\begin{array}{c}0.293^{* * *} \\
(0.046)\end{array}$ & $\begin{array}{c}-7.655^{* * *} \\
(1.731)\end{array}$ & $\begin{array}{c}-0.071^{* * *} \\
(0.023)\end{array}$ & $\begin{array}{c}-5.465^{* * *} \\
(1.128)\end{array}$ & $\begin{array}{c}-0.124^{* * *} \\
(0.027)\end{array}$ & $\begin{array}{c}-4.279 * * * \\
(0.884)\end{array}$ & $\begin{array}{c}0.328 * * * \\
(0.046)\end{array}$ & $\begin{array}{c}0.082 \\
(0.840)\end{array}$ & $\begin{array}{c}-0.176^{* * *} \\
(0.031)\end{array}$ \\
\hline Obse & 247,975 & 246,738 & 249,594 & 249,348 & 247,992 & 247,974 & 248,451 & 248,214 & 168,841 \\
\hline R-squared & 0.258 & 0.245 & 0.239 & 0.132 & 0.216 & 0.113 & 0.241 & 0.177 & 0.219 \\
\hline
\end{tabular}

Robust standard errors are reported in parentheses, clustered at the country level. ${ }^{* * *} \mathrm{p}<0.01,{ }^{* *} \mathrm{p}<0.05,{ }^{*} \mathrm{p}<0.1$

Notes: Dependent variables are dichotomous indicators as well as continuous variables (i.e. hours) for work supply in the last week. School attendance is a dichotomous variable referred to the last year. The sample includes children aged 5-14 in 38 countries. The table reports linear probability model results. Reference categories for reported dummy variables are 'higher education (i.e. more than primary)', 'female', 'female household's head', 'rural area'. Other controls include dummies for missing information on household head's education, wealth index, rural/urban area and country fixed effects. 
Table 21 - Lagged migration relative skill composition (RSC) and child labor (largest sample)

(1)

Any work Total hours Market
(4)

Hours in

market

work
(6)

(5)

Family Hours in

business family
(7)

Chores
(8)

Hours in

chores attendance

\begin{tabular}{|c|c|c|c|c|c|c|c|c|c|}
\hline $\begin{array}{l}\text { RSC_lagged*Hh } \\
\text { ow-skill }\end{array}$ & $\begin{array}{l}-0.034^{*} \\
(0.018)\end{array}$ & $\begin{array}{c}-3.140 * * \\
(1.280)\end{array}$ & $\begin{array}{l}-0.038^{*} \\
(0.020)\end{array}$ & $\begin{array}{l}-1.328^{*} \\
(0.748)\end{array}$ & $\begin{array}{l}-0.042^{*} \\
(0.022)\end{array}$ & $\begin{array}{l}-1.151^{*} \\
(0.574)\end{array}$ & $\begin{array}{c}-0.032 * * \\
(0.015)\end{array}$ & $\begin{array}{c}-1.162 * * \\
(0.447)\end{array}$ & $\begin{array}{c}0.000 \\
(0.016)\end{array}$ \\
\hline HhH low-skilled & $\begin{array}{c}0.024^{* * *} \\
(0.007)\end{array}$ & $\begin{array}{l}1.423^{* *} \\
(0.546)\end{array}$ & & $\begin{array}{c}0.581 \\
(0.373)\end{array}$ & $\begin{array}{l}0.026^{* *} \\
(0.010)\end{array}$ & $\begin{array}{c}0.343 \\
(0.287)\end{array}$ & $\begin{array}{c}0.024^{* * *} \\
(0.005)\end{array}$ & $\begin{array}{c}0.624^{* * *} \\
(0.173)\end{array}$ & $\begin{array}{c}-0.028 * * * \\
(0.008)\end{array}$ \\
\hline ge & $\begin{array}{c}0.045^{* * *} \\
(0.005)\end{array}$ & $\begin{array}{c}2.431^{* * *} \\
(0.195)\end{array}$ & $\begin{array}{c}0.033^{* * * *} \\
(0.002)\end{array}$ & $\begin{array}{c}1.019 * * * \\
(0.104)\end{array}$ & $\begin{array}{c}0.030 * * * \\
(0.002)\end{array}$ & $\begin{array}{c}0.763 * * * \\
(0.087)\end{array}$ & $\begin{array}{c}0.040 * * * \\
(0.005)\end{array}$ & $\begin{array}{c}1.066 * * * \\
(0.106)\end{array}$ & $\begin{array}{c}0.040 * * * \\
(0.003)\end{array}$ \\
\hline Iale & $\begin{array}{r}-0.07 \\
(0.0\end{array}$ & $\begin{array}{l}-0.5 \\
(0.4\end{array}$ & $\begin{array}{c}0.035^{* * * *} \\
(0.010)\end{array}$ & $\begin{array}{r}1.39 \\
(0.3\end{array}$ & $\begin{array}{c}0.035^{* * * *} \\
(0.012)\end{array}$ & $\begin{array}{c}1.072 * * * \\
(0.339)\end{array}$ & $\begin{array}{r}-0.1 \\
(0 .\end{array}$ & $\begin{array}{r}-2.8 \\
(0 .\end{array}$ & $\begin{array}{l}0.016^{* *} \\
(0.007)\end{array}$ \\
\hline ver in school & $\begin{array}{r}0.06 \\
(0.0\end{array}$ & $\begin{array}{r}-2.0 \\
(0.7\end{array}$ & & $\begin{array}{r}-1.43 \\
(0.3\end{array}$ & $\begin{array}{l}0 . \\
(0 .\end{array}$ & $\begin{array}{r}-1.1 \\
(0 .\end{array}$ & $\begin{array}{r}0.0 \\
(0\end{array}$ & & $\begin{array}{c}0.614^{* * * *} \\
(0.018)\end{array}$ \\
\hline IhH male & & $\begin{array}{r}0.92 \\
(0.2\end{array}$ & & $\begin{array}{r}0.41 \\
(0 .\end{array}$ & $* *$ & & & & \\
\hline $\begin{array}{l}\text { Iother li } \\
\text { ome }\end{array}$ & $\begin{array}{r}-0.01 \\
(0 .\end{array}$ & & & & & & & & k** \\
\hline $\begin{array}{l}\text { ather lives at } \\
\text { ome }\end{array}$ & & & & & & & & & $\begin{array}{l}0.010^{* *} \\
(0.005)\end{array}$ \\
\hline $\begin{array}{l}\text { of siblings aged } \\
15\end{array}$ & & & & & & & & & \\
\hline $\begin{array}{l}\text { J. of cl } \\
\text {.o. at l }\end{array}$ & & & & & & & & & $\begin{array}{c}-0.008 * * * \\
(0.003)\end{array}$ \\
\hline $\begin{array}{l}\text { J. of } \\
\text { dults }\end{array}$ & & & & & & & $\begin{array}{r}-0.0 \\
(0\end{array}$ & $\begin{array}{r}-0.2 \\
(0\end{array}$ & \\
\hline House & & & & & & & & & \\
\hline rth & $\begin{array}{l}-0 \\
(0 .\end{array}$ & $\begin{array}{r}-0.6 \\
(0 .\end{array}$ & $\begin{array}{r}-0.0 \\
(0 .\end{array}$ & $\begin{array}{r}-0 . \\
(0\end{array}$ & $\begin{array}{r}-0.1 \\
(0 .\end{array}$ & & & $\begin{array}{r}-0.3 \\
(0\end{array}$ & $\begin{array}{c}0.001 \\
(0.004)\end{array}$ \\
\hline rb & $\begin{array}{r}-0.052 \\
(0.00\end{array}$ & $\begin{array}{r}-5.35 \\
(0.6\end{array}$ & $\begin{array}{c}-0.123 * * * \\
(0.015)\end{array}$ & $\begin{array}{r}-2.5 \\
(0 .\end{array}$ & $\begin{array}{r}-0.1 \\
(0 .\end{array}$ & $\begin{array}{r}-2.5 \\
(0 .\end{array}$ & $\begin{array}{r}-0.0 \\
(0\end{array}$ & $\begin{array}{r}-1.1 \\
(0\end{array}$ & $\begin{array}{c}0.032 * * * \\
(0.007)\end{array}$ \\
\hline & & & & & & & & & \\
\hline & $74 * * *$ & $\begin{array}{c}5.979 * * * \\
(0.617)\end{array}$ & $\begin{array}{c}0.129 * * * \\
(0.016)\end{array}$ & $\begin{array}{c}3.170 * * * \\
(0.463)\end{array}$ & $\begin{array}{c}0.134 * * * \\
(0.018)\end{array}$ & $\begin{array}{c}2.618^{* * *} \\
(0.384)\end{array}$ & $\begin{array}{c}0.046^{* * *} \\
(0.010)\end{array}$ & $\begin{array}{c}1.369 * * * \\
(0.290)\end{array}$ & $\begin{array}{c}-0.103 * * * \\
(0.013)\end{array}$ \\
\hline $\mathrm{d}$ q & $\begin{array}{c}0.053^{* * *} \\
(0.009)\end{array}$ & $\begin{array}{c}4.583 * * * \\
(0.778)\end{array}$ & $\begin{array}{c}0.099 * * * \\
(0.018)\end{array}$ & $\begin{array}{c}2.428 * * * \\
(0.508)\end{array}$ & $\begin{array}{c}0.104 * * * \\
(0.019)\end{array}$ & $\begin{array}{c}1.900 * * * \\
(0.436)\end{array}$ & $\begin{array}{c}0.038 * * * \\
(0.011)\end{array}$ & $\begin{array}{c}0.940 * * * \\
(0.266)\end{array}$ & $\begin{array}{c}-0.077 * * * \\
(0.014)\end{array}$ \\
\hline d qu & $\begin{array}{c}0.045^{* * *} \\
(0.009)\end{array}$ & $\begin{array}{c}3.698 * * * \\
(0.831)\end{array}$ & $\begin{array}{c}0.086^{* * *} \\
(0.019)\end{array}$ & $\begin{array}{c}1.860 * * * \\
(0.475)\end{array}$ & $\begin{array}{c}0.085^{* * *} \\
(0.020)\end{array}$ & $\begin{array}{c}1.371^{* * *} \\
(0.413)\end{array}$ & $\begin{array}{c}0.032 * * * \\
(0.009)\end{array}$ & $\begin{array}{c}0.797 * * * \\
(0.242)\end{array}$ & $\begin{array}{c}-0.050 * * * \\
(0.009)\end{array}$ \\
\hline ho & $\begin{array}{c}0.022^{* * *} \\
(0.008)\end{array}$ & $\begin{array}{c}2.248^{* * *} \\
(0.717)\end{array}$ & $\begin{array}{c}0.046^{* * *} \\
(0.014)\end{array}$ & $1.123^{* *}$ & $\begin{array}{c}0.050 * * * \\
(0.015)\end{array}$ & & $7^{* *}$ & $4 * *$ & $\begin{array}{c}-0.032 * * * \\
(0.006)\end{array}$ \\
\hline onstant & $\begin{array}{c}0.293 * * * \\
(0.046)\end{array}$ & $\begin{array}{c}-7.674^{* * *} \\
(1.710)\end{array}$ & $\begin{array}{c}-0.071^{* * *} \\
(0.023)\end{array}$ & $\begin{array}{c}-5.463 * * * \\
(1.117)\end{array}$ & $\begin{array}{c}-0.124^{* * *} \\
(0.026)\end{array}$ & $\begin{array}{c}-4.284^{* * *} \\
(0.876)\end{array}$ & $\begin{array}{c}0.328^{* * *} \\
(0.046)\end{array}$ & $\begin{array}{c}0.065 \\
(0.839)\end{array}$ & $\begin{array}{c}-0.176^{* * *} \\
(0.031)\end{array}$ \\
\hline & & & & & & & & & 168,841 \\
\hline iquarea & 0.258 & 0.245 & 0.239 & 0.132 & 0.216 & 0.113 & 0.241 & 0.177 & 0.219 \\
\hline
\end{tabular}

Robust standard errors are reported in parentheses, clustered at the country level. ${ }^{* * *} \mathrm{p}<0.01,{ }^{* *} \mathrm{p}<0.05,{ }^{*} \mathrm{p}<0.1$

Notes: Dependent variables are dichotomous indicators as well as continuous variables (i.e. hours) for work supply in the last week. School attendance is a dichotomous variable referred to the last year. The sample includes children aged 5-14. The table report linear probability model results. The Relative Skill Composition (RSC) index is the log of the ratio of low-skilled to skilled labor in the lagged migrant relative to the resident population. Reference categories for reported dummy variables are 'higher education', 'female', 'female household's head', 'rural area'. Other controls include dummies for missing information on household head's education, wealth index, rural/urban area and country fixed effects . 
Table A1 - Migration relative skill composition RSC' and child labor in skilled households

\begin{tabular}{|c|c|c|c|c|c|c|c|c|c|}
\hline & Any work & $\begin{array}{c}(2) \\
\text { Total hours } \\
\text { of work }\end{array}$ & $\begin{array}{c}\text { (3) } \\
\text { Market } \\
\text { work }\end{array}$ & $\begin{array}{c}(4) \\
\text { Hours in } \\
\text { market } \\
\text { work }\end{array}$ & $\begin{array}{c}\text { (5) } \\
\text { Family } \\
\text { business }\end{array}$ & $\begin{array}{c}(6) \\
\text { Hours in } \\
\text { family } \\
\text { business }\end{array}$ & Chores & $\begin{array}{c}\text { (8) } \\
\text { Hours in } \\
\text { chores }\end{array}$ & $\begin{array}{c}\text { (9) } \\
\text { School } \\
\text { attendance }\end{array}$ \\
\hline RSC'*HhH hi-skilled & $\begin{array}{c}0.006 \\
(0.009)\end{array}$ & $\begin{array}{c}-0.572 \\
(0.470)\end{array}$ & $\begin{array}{c}-0.010 \\
(0.009)\end{array}$ & $\begin{array}{c}-0.549 * \\
(0.289)\end{array}$ & $\begin{array}{c}-0.015 \\
(0.010)\end{array}$ & $\begin{array}{c}-0.464^{*} \\
(0.240)\end{array}$ & $\begin{array}{c}0.001 \\
(0.007)\end{array}$ & $\begin{array}{c}0.100 \\
(0.192)\end{array}$ & $\begin{array}{c}0.005 \\
(0.006)\end{array}$ \\
\hline HhH high-skilled & $\begin{array}{l}-0.045^{*} \\
(0.026)\end{array}$ & $\begin{array}{l}-0.042 \\
(1.262)\end{array}$ & $\begin{array}{l}-0.009 \\
(0.022)\end{array}$ & $\begin{array}{c}0.745 \\
(0.714)\end{array}$ & $\begin{array}{c}0.011 \\
(0.022)\end{array}$ & $\begin{array}{c}0.750 \\
(0.638)\end{array}$ & $\begin{array}{l}-0.027 \\
(0.018)\end{array}$ & $\begin{array}{c}-0.869 \\
(0.623)\end{array}$ & $\begin{array}{c}0.021 \\
(0.026)\end{array}$ \\
\hline Constant & $\begin{array}{c}0.302 * * * \\
(0.046)\end{array}$ & $\begin{array}{c}-7.193 * * * \\
(1.656)\end{array}$ & $\begin{array}{c}-0.061^{* *} \\
(0.023)\end{array}$ & $\begin{array}{c}-5.250 * * * \\
(1.066)\end{array}$ & $\begin{array}{c}-0.114^{* * *} \\
(0.025)\end{array}$ & $\begin{array}{c}-4.175^{* * *} \\
(0.866)\end{array}$ & $\begin{array}{c}0.337 * * * \\
(0.046)\end{array}$ & $\begin{array}{c}0.269 \\
(0.836)\end{array}$ & $\begin{array}{c}-0.195 * * * \\
(0.032)\end{array}$ \\
\hline Observations & 247,975 & 246,738 & 249,594 & 249,348 & 247,992 & 247,974 & 248,451 & 248,214 & 168,841 \\
\hline R-squared & 0.258 & 0.244 & 0.239 & 0.132 & 0.216 & 0.113 & 0.241 & 0.177 & 0.218 \\
\hline
\end{tabular}

Robust standard errors are reported in parentheses, clustered at the country level. ${ }^{* * *} \mathrm{p}<0.01,{ }^{* *} \mathrm{p}<0.05,{ }^{*} \mathrm{p}<0.1$

Notes: Dependent variables are dichotomous indicators as well as continuous variables (i.e. hours) for work supply in the last week. School attendance is a dichotomous variable referred to the last year. The sample includes children aged 5-14. The table report linear probability model results. The

Relative Skill Composition (RSC') index is the log of the ratio of skilled (i.e. tertiary education) to unskilled labor in the migrant relative to the resident population. Other controls are as in Table 4. 
Table A2 - Migration relative skill composition (RSC') and child labor in unskilled households

\begin{tabular}{|c|c|c|c|c|c|c|c|c|c|}
\hline & $\begin{array}{c}\text { (1) } \\
\text { Any work }\end{array}$ & $\begin{array}{c}\text { (2) } \\
\text { Total hours } \\
\text { of work }\end{array}$ & Market work & $\begin{array}{c}\text { (4) } \\
\text { Hours in } \\
\text { market work }\end{array}$ & $\begin{array}{c}\text { (5) } \\
\text { Family } \\
\text { business }\end{array}$ & $\begin{array}{c}(6) \\
\text { Hours in } \\
\text { family } \\
\text { business }\end{array}$ & Chores & $\begin{array}{c}\text { (8) } \\
\text { Hours in } \\
\text { chores }\end{array}$ & $\begin{array}{c}\text { (9) } \\
\text { School } \\
\text { attendance }\end{array}$ \\
\hline RSC'*HhH low-skill & $\begin{array}{c}0.006 \\
(0.004)\end{array}$ & $\begin{array}{c}0.707 \\
(0.464)\end{array}$ & $\begin{array}{c}0.006 \\
(0.005)\end{array}$ & $\begin{array}{c}0.266 \\
(0.259)\end{array}$ & $\begin{array}{c}0.007 \\
(0.006)\end{array}$ & $\begin{array}{c}0.199 \\
(0.199)\end{array}$ & $\begin{array}{l}0.007^{*} \\
(0.003)\end{array}$ & $\begin{array}{l}0.301^{* *} \\
(0.141)\end{array}$ & $\begin{array}{l}-0.000 \\
(0.004)\end{array}$ \\
\hline HhH low-skilled & $\begin{array}{l}-0.001 \\
(0.015)\end{array}$ & $\begin{array}{l}-1.405 \\
(1.523)\end{array}$ & $\begin{array}{l}-0.003 \\
(0.016)\end{array}$ & $\begin{array}{l}-0.512 \\
(0.819)\end{array}$ & $\begin{array}{l}-0.005 \\
(0.016)\end{array}$ & $\begin{array}{l}-0.504 \\
(0.688)\end{array}$ & $\begin{array}{l}-0.003 \\
(0.011)\end{array}$ & $\begin{array}{l}-0.547 \\
(0.492)\end{array}$ & $\begin{array}{c}-0.028^{* *} \\
(0.012)\end{array}$ \\
\hline Constant & $\begin{array}{c}0.292 * * * \\
(0.046)\end{array}$ & $\begin{array}{c}-7.694 * * * \\
(1.713)\end{array}$ & $\begin{array}{c}-0.071^{* * *} \\
(0.023)\end{array}$ & $\begin{array}{c}-5.472 * * * \\
(1.122)\end{array}$ & $\begin{array}{c}-0.124^{* * *} \\
(0.026)\end{array}$ & $\begin{array}{c}-4.292 * * * \\
(0.880)\end{array}$ & $\begin{array}{c}0.328 * * * \\
(0.045)\end{array}$ & $\begin{array}{c}0.058 \\
(0.836)\end{array}$ & $\begin{array}{c}-0.176^{* * *} \\
(0.031)\end{array}$ \\
\hline Observations & 247,975 & 246,738 & 249,594 & 249,348 & 247,992 & 247,974 & 248,451 & 248,214 & 168,841 \\
\hline R-squared & 0.258 & 0.245 & 0.239 & 0.132 & 0.216 & 0.113 & 0.241 & 0.177 & 0.219 \\
\hline
\end{tabular}

Robust standard errors are reported in parentheses, clustered at the country level. ${ }^{* *} \mathrm{p}<0.01,{ }^{* *} \mathrm{p}<0.05,{ }^{*} \mathrm{p}<0.1$

Notes: Dependent variables are dichotomous indicators as well as continuous variables (i.e. hours) for work supply in the last week. School attendance is a dichotomous variable referred to the last year. The sample includes children aged 5-14. The table report linear probability model results. The Relative Skill Composition (RSC') index is the log of the ratio of skilled (i.e. tertiary education) to unskilled labor in the migrant relative to the resident population. Other controls are as in Table 4. 
Table A3 - Migration relative skill composition RSC and child labor in skilled households

\begin{tabular}{|c|c|c|c|c|c|c|c|c|c|}
\hline & Any work & $\begin{array}{c}\text { (2) } \\
\text { Total hours } \\
\text { of work }\end{array}$ & $\begin{array}{c}(3) \\
\text { Market } \\
\text { work }\end{array}$ & $\begin{array}{c}(4) \\
\text { Hours in } \\
\text { market } \\
\text { work }\end{array}$ & $\begin{array}{c}\text { (5) } \\
\text { Family } \\
\text { business }\end{array}$ & $\begin{array}{c}(6) \\
\text { Hours in } \\
\text { family } \\
\text { business }\end{array}$ & Chores & $\begin{array}{c}\text { (8) } \\
\text { Hours in } \\
\text { chores }\end{array}$ & $\begin{array}{c}(9) \\
\text { School } \\
\text { attendance }\end{array}$ \\
\hline RSC*HhH high-skilled & $\begin{array}{c}0.051 \\
(0.044)\end{array}$ & $\begin{array}{l}5.405^{* *} \\
(2.586)\end{array}$ & $\begin{array}{l}0.090^{*} \\
(0.051)\end{array}$ & $\begin{array}{c}3.350 * * \\
(1.588)\end{array}$ & $\begin{array}{c}0.109 * \\
(0.058)\end{array}$ & $\begin{array}{c}2.931 * * \\
(1.242)\end{array}$ & $\begin{array}{c}0.052 \\
(0.039)\end{array}$ & $\begin{array}{c}0.663 \\
(1.347)\end{array}$ & $\begin{array}{c}-0.068 * * \\
(0.025)\end{array}$ \\
\hline HhH high-skilled & $\begin{array}{c}-0.042^{* *} \\
(0.017)\end{array}$ & $\begin{array}{c}-2.887 * * * \\
(0.994)\end{array}$ & $\begin{array}{c}-0.057 * * * \\
(0.021)\end{array}$ & $\begin{array}{c}-1.532 * * \\
(0.656)\end{array}$ & $\begin{array}{c}-0.057 * * \\
(0.023)\end{array}$ & $\begin{array}{c}-1.203^{* *} \\
(0.532)\end{array}$ & $\begin{array}{c}-0.037 * * \\
(0.015)\end{array}$ & $\begin{array}{c}-0.769 * * \\
(0.291)\end{array}$ & $\begin{array}{c}0.052 * * * \\
(0.013)\end{array}$ \\
\hline Constant & $\begin{array}{c}0.302 * * * \\
(0.046)\end{array}$ & $\begin{array}{c}-7.165^{* * *} \\
(1.656)\end{array}$ & $\begin{array}{c}-0.061^{* *} \\
(0.023)\end{array}$ & $\begin{array}{c}-5.242 * * * \\
(1.066)\end{array}$ & $\begin{array}{c}-0.113 * * * \\
(0.025)\end{array}$ & $\begin{array}{c}-4.167 * * * \\
(0.866)\end{array}$ & $\begin{array}{c}0.338 * * * \\
(0.046)\end{array}$ & $\begin{array}{c}0.280 \\
(0.837)\end{array}$ & $\begin{array}{c}-0.195 * * * \\
(0.032)\end{array}$ \\
\hline Observations & 247,975 & 246,738 & 249,594 & 249,348 & 247,992 & 247,974 & 248,451 & 248,214 & 168,841 \\
\hline R-squared & 0.258 & 0.244 & 0.239 & 0.132 & 0.216 & 0.113 & 0.241 & 0.177 & 0.219 \\
\hline
\end{tabular}

Robust standard errors are reported in parentheses, clustered at the country level. ${ }^{* * *} \mathrm{p}<0.01,{ }^{* *} \mathrm{p}<0.05,{ }^{*} \mathrm{p}<0.1$

Notes: Dependent variables are dichotomous indicators as well as continuous variables (i.e. hours) for work supply in the last week. School attendance is a dichotomous variable referred to the last year. The sample includes children aged 5-14. The table report linear probability model results. The Relative

Skill Composition (RSC) index is the log of the ratio of low skilled to skilled labor in the migrant relative to the resident population. Other controls are as in Table 4. 
Table A4 - Child labor response to the WB-UN migration rate

(1) (2) (3) (4) Any work $\begin{gathered}\text { Total hours } \\ \text { of work }\end{gathered} \quad \begin{gathered}\text { Market } \\ \text { work }\end{gathered}$
(4)

Hours in

market
(5) (6)

(6)

Family

business family business
(7) (8)

(9)

Hours in School chores attendance

\begin{tabular}{|c|c|c|c|c|c|c|c|c|c|}
\hline $\begin{array}{l}\text { WB_Mig. rate*HhH } \\
\text { low-skill }\end{array}$ & $\begin{array}{c}-0.057^{* *} \\
(0.021)\end{array}$ & $\begin{array}{c}-4.820 * * \\
(2.230)\end{array}$ & $\begin{array}{l}-0.044 \\
(0.041)\end{array}$ & $\begin{array}{l}-2.148 \\
(1.621)\end{array}$ & $\begin{array}{l}-0.055 \\
(0.048)\end{array}$ & $\begin{array}{l}-1.497 \\
(1.288)\end{array}$ & $\begin{array}{c}-0.056^{* * *} \\
(0.020)\end{array}$ & $\begin{array}{c}-1.929 * * * \\
(0.695)\end{array}$ & $\begin{array}{l}0.054 * * \\
(0.020)\end{array}$ \\
\hline HhH low-skilled & $\begin{array}{c}0.023^{* * *} \\
(0.007)\end{array}$ & $\begin{array}{l}1.345^{* *} \\
(0.588)\end{array}$ & $\begin{array}{l}0.021 * \\
(0.010)\end{array}$ & $\begin{array}{c}0.560 \\
(0.430)\end{array}$ & $\begin{array}{l}0.024^{*} \\
(0.012)\end{array}$ & $\begin{array}{c}0.285 \\
(0.339)\end{array}$ & $\begin{array}{c}0.024 * * * \\
(0.005)\end{array}$ & $\begin{array}{c}0.610 * * * \\
(0.179)\end{array}$ & $\begin{array}{c}-0.035^{* * *} \\
(0.008)\end{array}$ \\
\hline Age & $\begin{array}{c}0.045^{* * *} \\
(0.005)\end{array}$ & $\begin{array}{c}2.432 * * * \\
(0.195)\end{array}$ & $\begin{array}{c}0.033^{* * *} \\
(0.002)\end{array}$ & $\begin{array}{c}1.019 * * * \\
(0.104)\end{array}$ & $\begin{array}{c}0.030 * * * \\
(0.002)\end{array}$ & $\begin{array}{c}0.764^{* * *} \\
(0.087)\end{array}$ & $\begin{array}{l}0.040 * * * \\
(0.005)\end{array}$ & $\begin{array}{c}1.067^{* * *} \\
(0.106)\end{array}$ & $\begin{array}{c}0.040 * * * \\
(0.003)\end{array}$ \\
\hline Male & $\begin{array}{c}-0.078 * * * \\
(0.017)\end{array}$ & $\begin{array}{l}-0.581 \\
(0.405)\end{array}$ & $\begin{array}{c}0.035^{* * *} \\
(0.010)\end{array}$ & $\begin{array}{c}1.394 * * * \\
(0.347)\end{array}$ & $\begin{array}{c}0.035^{* * *} \\
(0.012)\end{array}$ & $\begin{array}{c}1.072 * * * \\
(0.339)\end{array}$ & $\begin{array}{c}-0.125^{* * *} \\
(0.024)\end{array}$ & $\begin{array}{c}-2.807 * * * \\
(0.446)\end{array}$ & $\begin{array}{l}0.016 * * \\
(0.007)\end{array}$ \\
\hline Ever in school & $\begin{array}{c}0.060^{* * *} \\
(0.010)\end{array}$ & $\begin{array}{l}-2.001^{* *} \\
(0.748)\end{array}$ & $\begin{array}{c}0.003 \\
(0.009)\end{array}$ & $\begin{array}{c}-1.432 * * * \\
(0.385)\end{array}$ & $\begin{array}{c}0.001 \\
(0.008)\end{array}$ & $\begin{array}{c}-1.110 * * * \\
(0.365)\end{array}$ & $\begin{array}{c}0.067 * * * \\
(0.010)\end{array}$ & $\begin{array}{l}-0.603^{*} \\
(0.355)\end{array}$ & $\begin{array}{c}0.614 * * * \\
(0.018)\end{array}$ \\
\hline HhH male & $\begin{array}{l}0.010 * \\
(0.005)\end{array}$ & $\begin{array}{c}0.975^{* * *} \\
(0.245)\end{array}$ & $\begin{array}{l}0.014^{* *} \\
(0.006)\end{array}$ & $\begin{array}{c}0.432 * * * \\
(0.125)\end{array}$ & $\begin{array}{c}0.021^{* * *} \\
(0.007)\end{array}$ & $\begin{array}{c}0.395^{* * *} \\
(0.130)\end{array}$ & $\begin{array}{l}0.012 * \\
(0.006)\end{array}$ & $\begin{array}{c}0.324^{* *} \\
(0.157)\end{array}$ & $\begin{array}{l}-0.006 \\
(0.004)\end{array}$ \\
\hline Mother lives at home & $\begin{array}{c}-0.011^{* * *} \\
(0.004)\end{array}$ & $\begin{array}{l}-0.426 \\
(0.263)\end{array}$ & $\begin{array}{l}-0.000 \\
(0.006)\end{array}$ & $\begin{array}{l}-0.120 \\
(0.162)\end{array}$ & $\begin{array}{c}0.007 \\
(0.005)\end{array}$ & $\begin{array}{c}0.083 \\
(0.122)\end{array}$ & $\begin{array}{l}-0.005 \\
(0.004)\end{array}$ & $\begin{array}{c}-0.441^{* *} \\
(0.179)\end{array}$ & $\begin{array}{c}0.028 * * * \\
(0.006)\end{array}$ \\
\hline Father live & $\begin{array}{l}-0.006 \\
(0.004)\end{array}$ & $\begin{array}{c}0.272 \\
(0.420)\end{array}$ & $\begin{array}{c}0.001 \\
(0.007)\end{array}$ & $\begin{array}{c}0.297 \\
(0.178)\end{array}$ & $\begin{array}{c}0.005 \\
(0.006)\end{array}$ & $\begin{array}{l}0.371^{* *} \\
(0.156)\end{array}$ & $\begin{array}{c}-0.009 * * \\
(0.004)\end{array}$ & $\begin{array}{l}-0.125 \\
(0.200)\end{array}$ & $\begin{array}{l}0.010 * * \\
(0.005)\end{array}$ \\
\hline $\begin{array}{l}\text { N. of siblings aged 5- } \\
15\end{array}$ & $\begin{array}{l}-0.001 \\
(0.001)\end{array}$ & $\begin{array}{c}0.152 \\
(0.095)\end{array}$ & $\begin{array}{l}0.003^{*} \\
(0.002)\end{array}$ & $\begin{array}{c}0.096 \\
(0.066)\end{array}$ & $\begin{array}{l}0.003 * * \\
(0.002)\end{array}$ & $\begin{array}{c}0.070 \\
(0.056)\end{array}$ & $\begin{array}{l}-0.001 \\
(0.001)\end{array}$ & $\begin{array}{c}0.029 \\
(0.025)\end{array}$ & $\begin{array}{c}0.003 \\
(0.002)\end{array}$ \\
\hline $\begin{array}{l}\text { N. of children }<5 \text { y.o. } \\
\text { at home }\end{array}$ & $\begin{array}{l}0.004^{* *} \\
(0.001)\end{array}$ & $\begin{array}{l}0.198 * * \\
(0.094)\end{array}$ & $\begin{array}{l}0.002 * \\
(0.001)\end{array}$ & $\begin{array}{c}0.047 \\
(0.050)\end{array}$ & $\begin{array}{c}0.001 \\
(0.001)\end{array}$ & $\begin{array}{c}0.010 \\
(0.057)\end{array}$ & $\begin{array}{l}0.004 * * \\
(0.002)\end{array}$ & $\begin{array}{c}0.154^{* * *} \\
(0.048)\end{array}$ & $\begin{array}{c}-0.008 * * * \\
(0.003)\end{array}$ \\
\hline $\begin{array}{l}\text { N. of female adults at } \\
\text { home }\end{array}$ & $\begin{array}{c}-0.010^{* * *} \\
(0.002)\end{array}$ & $\begin{array}{c}-0.311^{* * *} \\
(0.100)\end{array}$ & $\begin{array}{l}-0.001 \\
(0.003)\end{array}$ & $\begin{array}{l}-0.081 \\
(0.070)\end{array}$ & $\begin{array}{l}-0.001 \\
(0.002)\end{array}$ & $\begin{array}{l}-0.100 * \\
(0.055)\end{array}$ & $\begin{array}{c}-0.008^{* * *} \\
(0.003)\end{array}$ & $\begin{array}{c}-0.246 * * * \\
(0.059)\end{array}$ & $\begin{array}{l}-0.000 \\
(0.001)\end{array}$ \\
\hline Household size & $\begin{array}{c}0.002 \\
(0.001)\end{array}$ & $\begin{array}{l}0.176^{*} \\
(0.090)\end{array}$ & $\begin{array}{c}0.002 \\
(0.002)\end{array}$ & $\begin{array}{c}0.085 \\
(0.056)\end{array}$ & $\begin{array}{c}0.002 \\
(0.002)\end{array}$ & $\begin{array}{l}0.100 * * \\
(0.043)\end{array}$ & $\begin{array}{c}0.000 \\
(0.001)\end{array}$ & $\begin{array}{c}0.043 \\
(0.035)\end{array}$ & $\begin{array}{c}0.000 \\
(0.001)\end{array}$ \\
\hline Birth order & $\begin{array}{l}-0.004 \\
(0.004)\end{array}$ & $\begin{array}{c}-0.683 * * * \\
(0.207)\end{array}$ & $\begin{array}{c}-0.008 * * * \\
(0.003)\end{array}$ & $\begin{array}{c}-0.295^{* *} \\
(0.111)\end{array}$ & $\begin{array}{l}-0.006^{* *} \\
(0.003)\end{array}$ & $\begin{array}{c}-0.213^{* *} \\
(0.091)\end{array}$ & $\begin{array}{l}-0.004 \\
(0.003)\end{array}$ & $\begin{array}{c}-0.319 * * * \\
(0.081)\end{array}$ & $\begin{array}{c}0.001 \\
(0.004)\end{array}$ \\
\hline Urban area & $\begin{array}{c}-0.052 * * * \\
(0.006)\end{array}$ & $\begin{array}{c}-5.358 * * * \\
(0.665)\end{array}$ & $\begin{array}{c}-0.123 * * * \\
(0.015)\end{array}$ & $\begin{array}{c}-2.592 * * * \\
(0.432)\end{array}$ & $\begin{array}{c}-0.132 * * * \\
(0.017)\end{array}$ & $\begin{array}{c}-2.513 * * * \\
(0.404)\end{array}$ & $\begin{array}{c}-0.032 * * * \\
(0.005)\end{array}$ & $\begin{array}{c}-1.145^{* * *} \\
(0.137)\end{array}$ & $\begin{array}{c}0.032 * * * \\
(0.007)\end{array}$ \\
\hline \multicolumn{10}{|l|}{ Wealth index } \\
\hline 1st quantile & $\begin{array}{c}0.074 * * * \\
(0.011)\end{array}$ & $\begin{array}{c}5.976^{* * *} \\
(0.615)\end{array}$ & $\begin{array}{c}0.129 * * * \\
(0.016)\end{array}$ & $\begin{array}{c}3.168 * * * \\
(0.462)\end{array}$ & $\begin{array}{c}0.133^{* * *} \\
(0.018)\end{array}$ & $\begin{array}{c}2.617 * * * \\
(0.382)\end{array}$ & $\begin{array}{c}0.046 * * * \\
(0.010)\end{array}$ & $\begin{array}{c}1.367 * * * \\
(0.289)\end{array}$ & $\begin{array}{c}-0.103^{* * *} \\
(0.013)\end{array}$ \\
\hline 2nd quantile & $\begin{array}{c}0.053^{* * *} \\
(0.009)\end{array}$ & $\begin{array}{c}4.580^{* * *} \\
(0.778)\end{array}$ & $\begin{array}{c}0.099 * * * \\
(0.018)\end{array}$ & $\begin{array}{c}2.427 * * * \\
(0.507)\end{array}$ & $\begin{array}{c}0.104^{* * *} \\
(0.019)\end{array}$ & $\begin{array}{c}1.899 * * * \\
(0.435)\end{array}$ & $\begin{array}{c}0.038 * * * \\
(0.011)\end{array}$ & $\begin{array}{c}0.938 * * * \\
(0.266)\end{array}$ & $\begin{array}{c}-0.077^{* * *} \\
(0.014)\end{array}$ \\
\hline 3rd quantile & $\begin{array}{c}0.044^{* * *} \\
(0.009)\end{array}$ & $\begin{array}{c}3.694^{* * *} \\
(0.828)\end{array}$ & $\begin{array}{c}0.086^{* * *} \\
(0.019)\end{array}$ & $\begin{array}{c}1.858 * * * \\
(0.473)\end{array}$ & $\begin{array}{c}0.085^{* * *} \\
(0.020)\end{array}$ & $\begin{array}{c}1.370 * * * \\
(0.411)\end{array}$ & $\begin{array}{c}0.032 * * * \\
(0.009)\end{array}$ & $\begin{array}{c}0.794^{* * *} \\
(0.242)\end{array}$ & $\begin{array}{c}-0.050 * * * \\
(0.009)\end{array}$ \\
\hline 4th quantile & $\begin{array}{c}0.022 * * * \\
(0.008)\end{array}$ & $\begin{array}{c}2.249 * * * \\
(0.715)\end{array}$ & $\begin{array}{c}0.047 * * * \\
(0.014)\end{array}$ & $\begin{array}{l}1.123 * * \\
(0.415)\end{array}$ & $\begin{array}{c}0.050 * * * \\
(0.015)\end{array}$ & $\begin{array}{c}0.823 * * \\
(0.371)\end{array}$ & $\begin{array}{l}0.017 * * \\
(0.007)\end{array}$ & $\begin{array}{c}0.514 * * \\
(0.250)\end{array}$ & $\begin{array}{c}-0.032 * * * \\
(0.006)\end{array}$ \\
\hline Constant & $\begin{array}{c}0.292^{* * *} \\
(0.046)\end{array}$ & $\begin{array}{c}-7.722 * * * \\
(1.712)\end{array}$ & $\begin{array}{c}-0.071 * * * \\
(0.023)\end{array}$ & $\begin{array}{c}-5.484 * * * \\
(1.123)\end{array}$ & $\begin{array}{c}-0.124 * * * \\
(0.027)\end{array}$ & $\begin{array}{c}-4.300 * * * \\
(0.880)\end{array}$ & $\begin{array}{c}0.327 * * * \\
(0.046)\end{array}$ & $\begin{array}{c}0.047 \\
(0.838)\end{array}$ & $\begin{array}{c}-0.175^{* * *} \\
(0.031)\end{array}$ \\
\hline Observations & 247,975 & 246,738 & 249,594 & 249,348 & 247,992 & 247,974 & 248,451 & 248,214 & 168,841 \\
\hline R-squared & 0.258 & 0.244 & 0.239 & 0.132 & 0.216 & 0.113 & 0.241 & 0.177 & 0.219 \\
\hline
\end{tabular}

Robust standard errors are reported in parentheses, clustered at the country level. ${ }^{* * *} \mathrm{p}<0.01,{ }^{* *} \mathrm{p}<0.05,{ }^{*} \mathrm{p}<0.1$

Notes: Dependent variables are dichotomous indicators as well as continuous variables (i.e. hours) for work supply in the last week. School attendance is a dichotomous variable referred to the last year. The sample includes children aged 5-14 in 38 countries. The table reports linear probability model results. Reference categories for reported dummy variables are 'higher education (i.e. more than primary)', 'female', 'female household's head', 'rural area'. Other controls include dummies for missing information on household head's education, wealth index, rural/urban area and country fixed effects. 